Mayara Colleti

A experiência da paternidade na meia-idade na perspectiva de pais, mães e seus/suas filhos (as) 



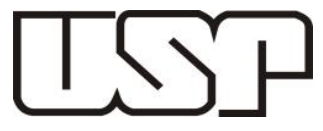

FFCLRP-USP

the

$(c-s)$

UNIVERSIDADE DE SÃO PAULO

FACULDADE DE FILOSOFIA, CIÊNCIAS E LETRAS DE RIBEIRÃO PRETO

DEPARTAMENTO DE PSICOLOGIA

PROGRAMA DE PÓS-GRADUAÇÃO EM PSICOLOGIA

LEPPS - Laboratório de Ensino e Pesquisa em Psicologia da Saúde

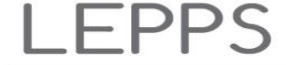

Laboratório de Ensino e Pesquis em Psicologia da Saúde

Mayara Colleti

A experiência da paternidade na meia-idade na perspectiva de pais, mães e seus/suas filhos(as)

Versão original

Dissertação apresentada à Faculdade de Filosofia, Ciência e Letras de Ribeirão Preto da Universidade de São Paulo, como parte das exigências para a obtenção do título de Mestre em Ciências.

Área de Concentração: Psicologia em Saúde e Desenvolvimento.

Orientador: Prof. Dr. Manoel Antônio dos Santos

Ribeirão Preto - SP 
Autorizo a reprodução e divulgação total ou parcial deste trabalho, por qualquer meio convencional ou eletrônico, para fins de estudo e pesquisa, desde que citada a fonte.

\section{Colleti, Mayara}

A experiência da paternidade na meia-idade na perspectiva de pais, mães e seus/suas filhos(as). Ribeirão Preto, 2017.

155 p.: il.; $30 \mathrm{~cm}$

Dissertação de Mestrado apresentada à Faculdade de Filosofia, Ciências e Letras de Ribeirão Preto-USP. Área de concentração: Psicologia em Saúde e Desenvolvimento. Orientador: Santos, Manoel Antônio dos.

1. Paternidade. 2. Meia-idade. 3. Pais. 4. Mães. 5 Filhos. 6. Familia. 
Este estudo foi desenvolvido junto ao Laboratório de Ensino e Pesquisa em Psicologia da Saúde.

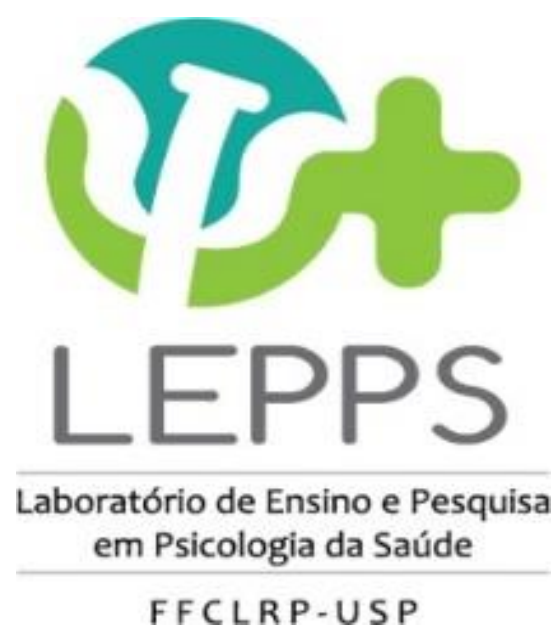

Apoio financeiro:

Esta Dissertação de Mestrado foi financiada pela Fundação de Amparo à Pesquisa do Estado de São Paulo (FAPESP), mediante a concessão de bolsa de mestrado, processo número 2015/02166-9, com vigência de agosto de 2015 a julho de 2017.

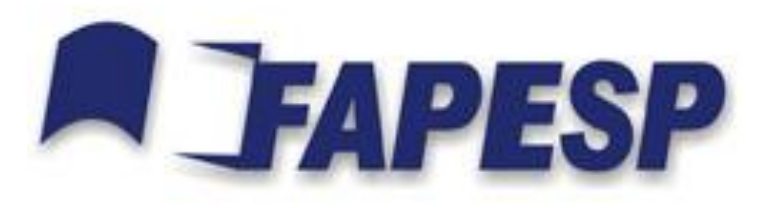



Nome: Colleti, Mayara

Título: A experiência da paternidade na meia-idade na perspectiva de pais, mães e seus/suas filhos(as)

Dissertação apresentada à Faculdade de Filosofia, Ciências e Letras de Ribeirão Preto da Universidade de São Paulo para obtenção do título de Mestre em Ciências. Área de Concentração: Psicologia em Saúde e Desenvolvimento.

Aprovada em: / 2017

Comissão Julgadora

Prof.(a) Instituição:

Julgamento: Assinatura:

Prof.(a) Instituição:

Julgamento: Assinatura:

Prof.(a) Instituição:

Julgamento: Assinatura:

Prof.(a) Instituição:

Julgamento: Assinatura: 



\section{AGRADECIMENTOS}

Ao Prof. Dr. Manoel Antônio dos Santos, por ter me acolhido calorosa e gentilmente em seu Grupo de Pesquisa. Pelas oportunidades oferecidas ao longo deste percurso, apresentando-me os possíveis caminhos da pesquisa. Por sempre acreditar em meu potencial e me instigar a fazer e buscar sempre oferecer o melhor de mim. Pela disposição e disponibilidade de ensinar, pela paixão de compartilhar sua experiência e seu encantamento pelo conhecimento, auxiliando-me a ampliar o conhecimento de mim mesma enquanto psicóloga e pesquisadora.

Aos/às queridos/as colegas do Laboratório de Ensino e Pesquisa em Psicologia da Saúde (LEPPS-FFCLRP-USP-CNPq), por compartilharem comigo não só seus aprendizados acadêmicos e estarem sempre dispostos a colaborar com o desenvolvimento dos integrantes do nosso grupo de pesquisa, mas também por permitirem que eu conhecesse um pouquinho da história singular de cada um.

Ao Prof. Dr. Geraldo Romanelli e a Profa. Dra. Daniela Centenaro Levandowski, pela participação na banca do Exame de Qualificação de Mestrado, pela disponibilidade imediata, pelas críticas e elogios e por me estimularem a seguir em frente, enriquecendo o processo de desenvolvimento do meu estudo.

Ao meu amado amigo e eterno professor Dr. Fabio Scorsolini-Comin, por ter me apresentado o universo da pesquisa de forma tão generosa, encaminhando-me $\mathrm{e}$ incentivando-me cuidadosamente a prosseguir. Por me permitir permanecer em sua vida e acompanhar seus passos. Pelos cafés oferecidos nos momentos de dúvidas e incertezas. Pelos abraços e desejos de boa sorte nos momentos em que nos questionávamos o sentido de alguns acontecimentos em nossas vidas.

Aos meus pais, Geraldo e Cleusa, por acreditarem em mim, independentemente de compreenderem e conhecerem minhas escolhas. Por me permitirem conhecer caminhos que eles jamais tiveram a oportunidade de trilhar. Por terem me ensinado que o mais importante na vida é respeitar as pessoas e que, o resto, é só uma questão de luta e tempo para conquistar. Pela fé e por jamais terem desistido da nossa família, mesmo com a vida teimando em nos provocar e testar nossas capacidades e limites. Por oferecer colos constantes, na chegada e na partida. 
Às minhas três queridas irmãs, Maricele, Mariane e Marina, por me completarem naquilo que eu não sou. Por insistirem nos almoços e cafés da manhã em familia, mesmo quando cada uma parece estar ocupada demais com seus compromissos. Pelos abraços de chegada e de partida. Jamais conseguirei expressar o prazer e a gratidão por tê-las em minha vida.

Aos meus amados sobrinhos, Luís Felipe e Maria Clara, por colorirem minha vida de maneira jamais imaginada. Por me permitirem conhecer um amor inexplicável. Por terem me apresentado um universo de cuidado e desafios.

À minha avó, que independentemente dos seus passos terem ficados mais lentos e sua voz não mais se fazer presente, continua me acolhendo com seu olhar caloroso e toque delicado. Obrigada por me permitir que eu a acompanhe nesses momentos tão difíceis. Obrigada por me fazer refletir sobre o verdadeiro sentido da vida.

Ao Bruno, meu noivo e companheiro de vida há 12 anos. Obrigada por ter permanecido incondicionalmente ao meu lado e me acompanhado durante todos esses anos. Pelo carinho, amor, respeito, dedicação e paciência. Por permitir que nos encontrássemos em meio às nossas diferenças. Por compartilhar comigo um projeto de vida e me ensinar sobre o amor e companheirismo.

À Janaina, minha colega de laboratório e grande amiga, pela escuta ativa e atenciosa em tantos momentos cruciais de minha vida. Obrigada por estar ao meu lado, mesmo nas ocasiões em que não sabíamos onde nossas escolhas iriam nos levar. Mesmo quando descobrimos que as coisas não eram como imaginávamos. Espero que você fique e me permita continuar fazendo parte de sua vida.

Às familias participantes deste estudo, que gentilmente me permitiram conhecer suas histórias, abrindo as portas de suas casas e me proporcionando momentos encantadores de intimidade compartilhada. Sem vocês esse trabalho seria impossível.

Ao apoio financeiro concedido pela Fundação de Amparo à Pesquisa do Estado de São Paulo (FAPESP), na forma de Bolsa de Mestrado (processo número 2015/02166-9), no período de agosto de 2015 e julho de 2017. Agradeço especialmente às contribuições oferecidas pelo(a) consultor(a) ad hoc, que contribuiu para o aperfeiçoamento deste estudo. 


\section{RESUMO}

Colleti, M. (2017). A experiência da paternidade na meia-idade na perspectiva de pais, mães e seus/suas filhos(as). Dissertação de Mestrado, Faculdade de Filosofia, Ciências e Letras de Ribeirão Preto, Universidade de São Paulo, Ribeirão Preto, SP.

O conceito de paternidade e sua vivência tornaram-se alvos de intensa investigação na literatura científica a partir do início dos anos 1970. Os estudos realizados destacam os acelerados processos de mudanças estruturais e organizacionais que incidem na família e na sociedade, que redefinem constantemente o entendimento que se tem sobre a paternidade, intensificando assim, o interesse em compreender a vivência paterna nos mais diversos contextos. Apesar da discussão que gravita em torno dessa temática, no que diz respeito à idade, os estudos existentes se concentram na vivência de pais adolescentes e adultos e na relação destes com seus filhos e companheiras. O objetivo do presente estudo foi compreender a experiência da paternidade na meia-idade a partir da perspectiva de pais, mães e filhos envolvidos. Trata-se de um estudo de caráter exploratório, descritivo, de corte transversal, amparado na abordagem qualitativa de pesquisa, no qual utilizou-se o estudo de caso múltiplo como estratégia metodológica. Os participantes deste estudo foram membros de quatro famílias, denominadas de: Familia Campos, Familia Sampaio, Familia Azevedo e Familia Pires. Os instrumentos utilizados para a coleta de dados foram: (a) Formulário de Dados Sociodemográficos, que engloba o Critério de Classificação Econômica Brasil; (b) Roteiro de Entrevista Semiestruturada realizada com o pai; (c) Roteiro de Entrevista Semiestruturada realizada com a mãe; (d) Roteiro de Entrevista Semiestruturada realizada com o(a) filho(a); (e) Desenho da Família (DF), aplicado nos filhos menores de 12 anos; (f) Genograma, aplicado a todos os membros da familia em conjunto e, (g) Diário de campo. As entrevistas foram gravadas em áudio e, posteriormente, transcritas na íntegra. O corpus de pesquisa foi organizado por meio de análise de conteúdo temática e a análise e interpretação dos dados pautou-se na teoria psicanalítica e na literatura disponível sobre o tema da paternidade. A partir da análise do material coletado, pôde-se elaborar, em diálogo com a literatura, três categorias temáticas: (a) Construindo uma família: Adaptações da conjugalidade às novas experiências de ser pai; (b) Que pai eu sou e que pai eu quero ser? e, (c) Potencialidades e dificuldades da paternidade na meia-idade. Os resultados permitiram desvelar a paternidade na meia-idade como uma vivência composta por múltiplas articulações. A 
conjugalidade e a reavaliação do modelo transmitido pelo próprio genitor revelaram-se como aspectos importantes no exercício paterno e nas expectativas em relação ao desempenho desse papel. Dentre as especificidades da experiência paterna na meia-idade, a maturidade e a estabilidade financeira foram apontadas como potencialidade desejáveis dessa vivência, enquanto que a indisposição física e o receio de talvez não ser capaz de acompanhar o processo de desenvolvimento da(o) filha(o) foram caracterizados como barreiras/dificuldades. Espera-se que este estudo possa fomentar novas investigações acerca da vivência paterna em diferentes etapas do ciclo de vida, a partir do relato dos seus próprios protagonistas e daqueles que com eles compartilham tal vivência.

Palavras-chave: paternidade; meia-idade; pais; mães; filhos; família. 


\begin{abstract}
Colleti, M. (2017). The experience of fatherhood in middle-age from the perspective of fathers, mothers and their children. Master's Dissertation. Faculty of Philosophy, Sciences and Letters at Ribeirão Preto, University of São Paulo, Ribeirão Preto, São Paulo, Brazil.
\end{abstract}

The concept of fatherhood and its experience became subject of intense research in scientific literature from the beginning of the 1970s. Studies emphasize the accelerated processes of structural and organizational changes that affect both family and society, which constantly redefine the understandings about paternity, thus intensifying the interest in comprehending paternal experience in several diverse contexts. Despite many discussions surrounding this subject, regarding age, most of the studies focus on the experience of fatherhood during adolescence and young adulthood, and their relations with their children and spouses. The present study aimed to comprehend the experience of fatherhood in middle-age from the perspective of fathers, mothers and children. This is an exploratory, descriptive and cross-sectional study. Participants were members of four families named: Campos, Sampaio, Azevedo and Pires. Instruments used for data collection were: (a) Sociodemographic form, which includes the Brazilian Economic Classification Criterion; (b) Semistructured interview with fathers; (c) Semistructured interview with mothers; (d) Semistructured interview with sons and/or daughters; (e) Family Drawing (FD), used with children younger than 12 years old; (f) Genogram, used with all members of the Family together; and (e) Field diary. Interviews were audiorecorded and transcribed in full. Corpus of research was organized through content analysis in thematic modality, and data interpretation was based on psychoanalytic theory and on the available literature regarding fatherhood. The analysis of collected data, along with dialogues with literature, enables the development of three thematic categories: (a) Building a family: Adaptations of conjugality to the new experiences of being a father; (b) What father am I and what father do I want to be?; and (c) Strengths and weaknessess of fatherhood in middle-age. Results showed fatherhood in middle-age as an experience composed by multiple articulations. Conjugality and reassessment of the model provided by their own parents were revealed as important aspects to the exercise of fatherhood and to the expectations regarding performance of this role. Among the specifities of the experience of fatherhood in middle-age, maturity and financial stability were considered 
desired strengths, whereas physical indisposition and the fear of not being able to follow children's development were characterized as weaknesses/barriers. We expect that this study can foment new research approaching the experience of fatherhood in different stages of life cycle, from the perspective of the main characters and those with whom they share such experience.

Keywords: fatherhood; middle-age; fathers; mothers; children; family. 


\section{LISTA DE TABELAS}

Tabela 1. Caracterização das famílias com relação aos cônjuges, filhos e suas idades .54

Tabela 2. Caracterização da família Campos em termos de integrantes, estado civil, escolaridade ocupação/profissão, idade, religião e classificação socioeconômica

Tabela 3. Caracterização da família Sampaio em termos de integrantes, estado civil, escolaridade ocupação/profissão, idade, religião e classificação socioeconômica

Tabela 4. Caracterização da família Azevedo em termos de integrantes, estado civil, escolaridade ocupação/profissão, idade, religião e classificação socioeconômica

Tabela 5. Caracterização da família Pires em termos de integrantes, estado civil, escolaridade ocupação/profissão, idade, religião e classificação socioeconômica 91 



\section{LISTA DE FIGURAS}

Figura 1. Genograma da família Campos .65

Figura 2. Genograma da família Sampaio …………………………………………........

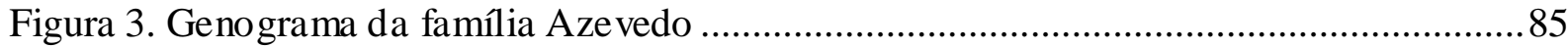

Figura 4. Genograma da família Pires ........................................................................92 



\section{LISTA DE SIGLAS}

ABEP Associação Brasileira de Empresas de Pesquisa

CCEB Critério de Classificação Econômica Brasil

CEP Comitê de Ética em Pesquisa

DC Diário de campo

DF Desenho da Família

FAPESP Fundação de Amparo à Pesquisa do Estado de São Paulo

FFCLRP Faculdade de Filosofia, Ciências e Letras de Ribeirão Preto

LEPPS Laboratório de Ensino e Pesquisa em Psicologia da Saúde

USP Universidade de São Paulo

OMS Organização Mundial da Saúde

TCLE Termo de Consentimento Livre e Esclarecido 



\section{SUMÁRIO}

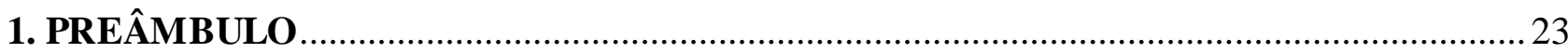

2. INTRODUÇÃ

2.1. Tornar-se pai, tornar-se mãe: Concepções sobre a parentalidade ...................................28

2.2. Paternidade em tempos de mudanças: Contextualizando a paternidade na

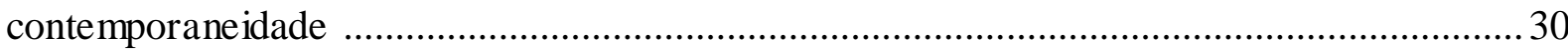

2.3. Concepções sobre a meia-idade: Articulações com a temática paternidade ..................... 36

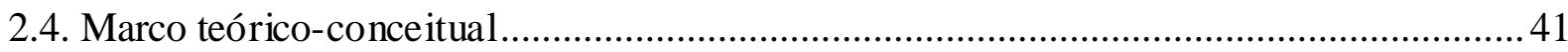

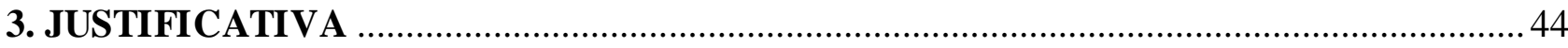

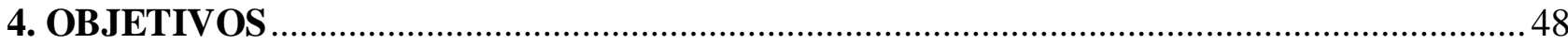

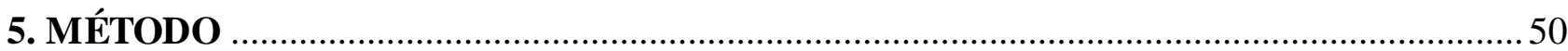

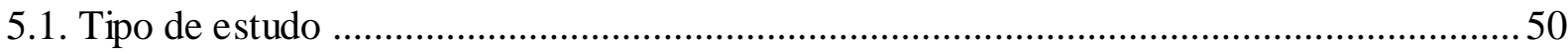

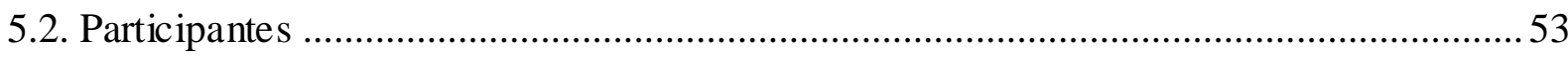

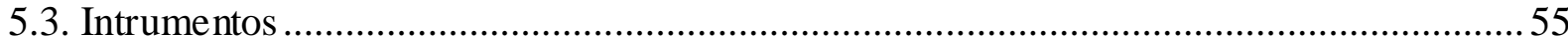

5.3.1. Formulário de Dados Sociodemográficos .........................................................55

5.3.2. Roteiros de Entrevistas Semiestruturados ...................................................... 55

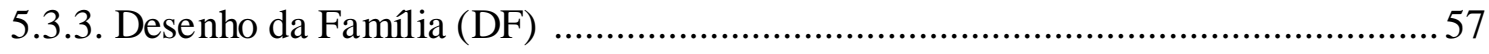

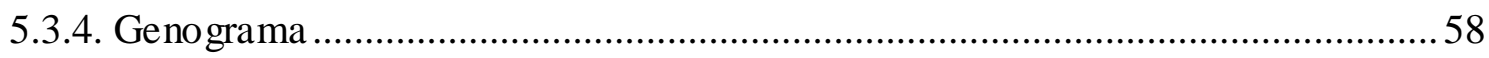

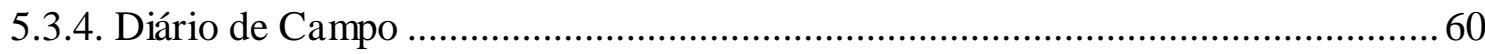

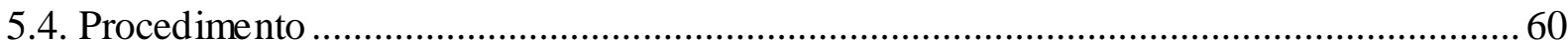

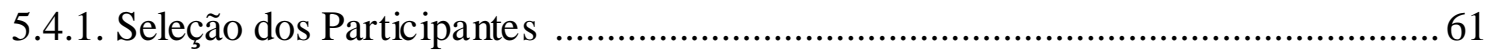

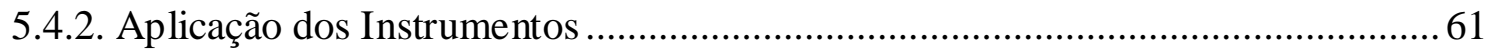

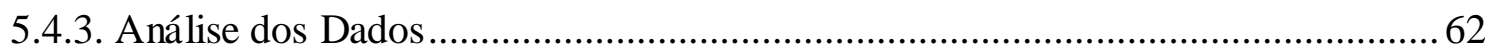

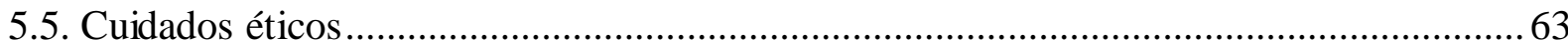




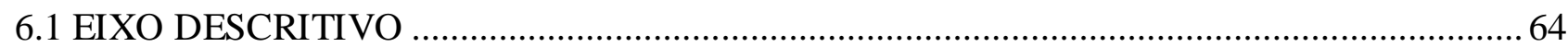

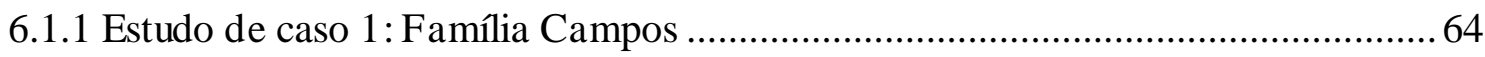

6.1.2 Estudo de caso 2: Família Sampaio .................................................................. 73

6.1.3 Estudo de caso 3: Família Azevedo ....................................................................... 84

6.1.6 Estudo de caso 4: Família Pires .........................................................................99

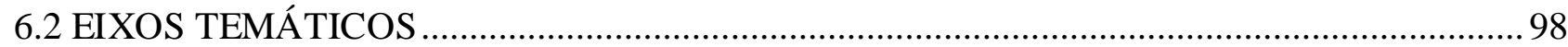

6.2.1 Construindo uma família: adaptações da conjugalidade às novas experiências de ser pai................................................................................98

6.2.2 Que pai eu sou e que pai eu quero ser?.................................................104

6.2.2 Potencialidades e desafios da paternidade na meia-idade......................111

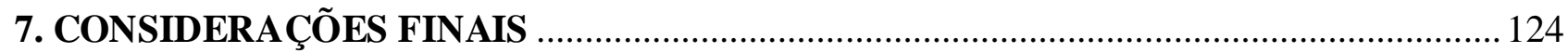

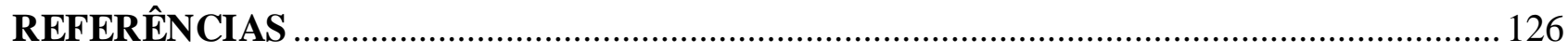

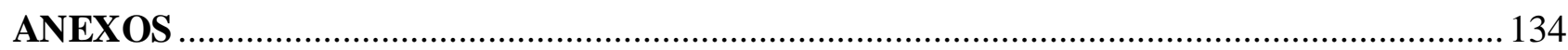

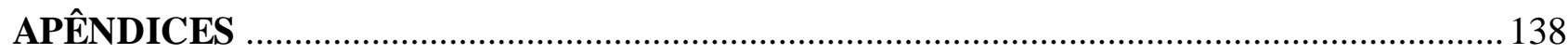




\section{PREÂMBULO}

A aproximação com a temática da paternidade e o interesse na realização do presente estudo remontam a trajetória de minhas escolhas como aluna de graduação em Psicologia e dos elementos que me motivaram a enveredar pelo campo da pesquisa científica. Ingressei no curso de graduação em Psicologia da Universidade Federal do Triângulo Mineiro (UFTM), no município de Uberaba, MG, em março de 2010 e, já no segundo semestre daquele mesmo ano comecei a me interessar pelo universo da pesquisa científica. Foi durante a disciplina de Psicologia do Desenvolvimento I, ministrada no segundo período de graduação pela Prof. Dra. Conceição Aparecida Serralha, que tive oportunidade de fazer parte de seu grupo de pesquisa, quando me dediquei a investigar a díade mãe-bebê a partir dos diferentes métodos de aleitamento.

A temática maternidade tangenciou, assim, minha primeira iniciação científica, possibilitando algumas reflexões que seriam fundamentais no despertar de meu interesse posterior pela temática paternidade. Ao cursar, no quinto período da graduação, uma disciplina ministrada pelo Prof. Dr. Fabio Scorsolini-Comin, tive a oportunidade de refletir acerca dos diversos atores envolvidos na parentalidade. Nessa ocasião, meus conhecimentos acerca dos numerosos estudos na temática da maternidade - assim como o contato com a literatura que tratava das transformações e revisões do conceito de familia na contemporaneidade - despertaram em mim o desejo de estudar a figura paterna e suas experiências no contexto familiar. Desejo que, em um primeiro momento, partia da curiosidade de investigar apenas o que estava sendo publicado na literatura sobre a vivência da paternidade, mas que, sob a preciosa orientação do Prof. Dr. Fabio, acabou por se transmutar em um tema de interesse central em minha formação acadêmica.

Durante minhas tentativas de compreender o estado da arte da temática paternidade verifiquei que, apesar das discussões acadêmicas que gravitam em torno dessa temática, no que diz respeito à vivência da paternidade em diferentes fases do ciclo vital, deparei-me com escassez de estudos. Foram essas observações que deram origem, em 2013, ao meu projeto de iniciação científica, inicialmente intitulado: "Ser pai aos 40: relatos de homens que se tornaram pais tardiamente", financiado pelo $\mathrm{CNPq}$ e que culminou com a elaboração de minha monografia de conclusão de curso e no artigo publicado: "Pais de primeira viagem: A experiência da paternidade na meia-idade". Participaram dessa investigação - exploratória e pautada na abordagem qualitativa quatro homens heterossexuais, que se tornaram pais pela primeira vez após os 40 anos d€ 
idade. Os relatos obtidos permitiram inferir as múltiplas articulações que compõem a vivência da paternidade nessa idade. Dentre os principais resultados alcançados, destacam-se: a importância atribuída ao modelo do próprio genitor na construção do modo de ser pai dos participantes; os desafios característicos da meia-idade, como mudanças corporais e cognitivas, que se tornaram ainda mais evidentes na relação pai e filho; e as repercussões da paternidade na conjugalidade e nas relações familiares e sociais, marcadas por alternância entre afastamentos e aproximações ocorridas após o nascimento do bebê.

Assim, à medida que os discursos dos participantes do referido estudo revelaram o modo como a relação estabelecida com o filho e a esposa contribuía e também os desafiava na experiência da paternidade nessa etapa do ciclo vital, pude tecer reflexões acerca da importância de ouvir e dar voz aos diferentes atores envolvidos nessa vivência singular. Esses desdobramentos despertaram meu interesse em prosseguir e aprofundar os estudos acerca da temática em questão, alimentando meu desejo de prosseguir minha formação acadêmica junto ao Programa de Pós-Graduação em Psicologia da Faculdade de Filosofia, Ciências e Letras de Ribeirão Preto (FFCLRP-USP). Para tanto, elaborei meu projeto de mestrado, sob a orientação do Prof. Dr. Manoel Antônio dos Santos, que concebeu comigo a ideia de conhecer como os demais membros da família compreendem a experiência da paternidade após os 40 anos, dando origem à pergunta de pesquisa que anima o presente estudo: Como os diferentes atores envolvidos na vivência da paternidade na meia-idade, ou seja, pais, mães e filhos, compreendem essa experiência?

O percurso de organização desta Dissertação de Mestrado foi estruturado nas seguintes seções:

Introdução - Este tópico será apresentado a partir de quatro temas, que remontam o percurso teórico que fundamenta o presente estudo: (1) Torna-se pai, tornar-se mãe: Concepções sobre a parentalidade; (2) Paternidade em tempos de mudanças: Contextualizando a paternidade na contemporaneidade, (3) Concepções sobre a meiaidade: Articulações com a temática paternidade; (4) Marco teórico-conceitual.

Método - Neste tópico serão abordados os aspectos relativos ao percurso metodológico que orientou o estudo, de forma a explicitar o delineamento de pesquisa, a estratégia metodológica adotada, os participantes, os instrumentos, os procedimentos de coleta e análise de dados, e os cuidados éticos envolvidos no desenvolvimento da pesquisa. 
Resultados e Discussão - Neste tópico serão contemplados os quatro estudos de caso, nos quais será apresentada uma descrição dos membros das famílias e a contextualização do encontro da pesquisadora com cada um deles, assim como as categorias temáticas elaboradas a partir da triangulação entre as diferentes fontes (instrumentos e materiais) utilizadas como recursos de interação da pesquisadora com os participantes e o ambiente doméstico.

Considerações Finais - Neste tópico serão apresentadas as elaborações finais desta Dissertação de Mestrado, levando-se em consideração tanto os aspectos relativos aos resultados da pesquisa, quanto as percepções da pesquisadora em relação ao desenvolvimento do estudo, e suas implicações e contribuições potenciais para a compreensão da vivência paterna na meia-idade

Por fim, serão apresentadas as referências utilizadas para fundamentar o estudo, seguidas dos apêndices e anexos que complementam a Dissertação. 



\section{INTRODUÇÃ̃}

\subsection{Torna-se pai, tornar-se mãe: Concepções sobre a parentalidade}

Os processos psíquicos e as mudanças subjetivas produzidas nos pais a partir do desejo e/ou nascimento de um filho têm ocupado um campo vasto de pesquisa nas áreas da Psicologia e da Psicanálise. O termo parentalidade é um neologismo de extração recente, que começou a ser utilizado na literatura psicanalítica francesa a partir dos anos 1960 para assinalar a dimensão de processo e de construção no exercício da relação dos pais com os filhos (Zornig, 2010). O conceito de parentalidade diz respeito ao conjunto de ações desempenhadas pelas figuras parentais junto aos seus filhos, no sentido de promover seu desenvolvimento da forma mais plena possível, utilizando-se, para tal, tanto de recursos disponíveis na família, quanto fora dela, no espaço das relações sociais estabelecidas na comunidade (Cruz, 2005).

Dentre os elementos que conectam as figuras parentais e seus filhos encontra-se o vínculo biológico, que concerne à concepção e origem genética do indivíduo; o parentesco, que se refere ao vínculo estabelecido entre dois indivíduos com relação a uma genealogia e que determina seu pertencimento a um grupo. A filiação se refere ao reconhecimento jurídico desse pertencimento, de acordo com as leis sociais vigentes estabelecidas no grupo. Já a parentalidade envolve os cuidados básicos com alimentação, vestuário, educação e saúde, reproduzidas no cotidiano das famílias (Zambrano, 2006).

Segundo Houzel (2004), para alcançar a parentalidade é preciso 'tornar-se pai”, o que envolve um processo complexo, no qual é necessário considerar três eixos e, em torno destes, articular o conjunto das funções adquiridas pelos pais. $\mathrm{O}$ primeiro eixo se refere ao exercício da parentalidade, o qual implica um domínio que transcende o indivíduo, sua subjetividade e seus comportamentos, e que organiza a parentalidade situando cada sujeito no seu papel parental e na cadeia transgeracional. O segundo eixo envolve a experiência da parentalidade, que é subjetiva, com uma faceta tanto consciente como inconsciente, que deriva do fato de vir a ser mãe/pai e de ocupar os papéis parentais. Por fim, tem-se o terceiro eixo, que concerne à prática da parentalidade, que engloba as experiências diárias entre pais e filhos (Jager \& Bottoli, 2011).

Para Cruz (2005), o "ser pai" e o "ser mãe" tendem a resultar de uma concordância entre os cônjuges ao decidirem formar uma familia por excelência, a partir de parâmetros tradicionais de família regulados pelas sociedades ocidentais e também 
pela concepção católica cristã: um homem, uma mulher e sua prole. Nesse sentido, os pais seriam investidos da responsabilidade de criar e cuidar de uma criança até esta ser considerada independente, sair de casa e constituir seu próprio núcleo familiar. Essa ideia de família apregoada socialmente tem sido abordada em muitos estudos, retomando os modelos internalizados de um ser família ou de um ser pai e ser mãe.

Julien (2000) e Roudinesco (2003) discutem a questão do 'tornar-se pai’ ou "tornar-se mãe" na atualidade, mais como dependente da história individual de cada um dos pais e de uma lógica do desejo do que de um modelo de família nuclear tradicional. Para Julien (2000), a modernidade introduziu uma disjunção entre o público e o privado e entre a conjugalidade e a parentalidade, em que os arranjos familiares não dependem somente da parentalidade e sim do desejo entre casais de estabelecerem relações íntimas. Assim, as relações conjugais são mantidas no espaço privado e dependem do desejo de cada um dos cônjuges. No entanto, ao decidir ter filhos, o casal ou indivíduo possibilita que o espaço público invada o espaço privado da conjugalidade, organizando dessa forma as relações de parentesco e definindo as responsabilidades dos pais e do Estado em relação às crianças (Zornig, 2010).

Roudinesco (2003) aprofunda sua discussão com base nas diversas mudanças ocorridas na família ao longo da história ocidental, fazendo a distinção de grandes períodos de evolução da mesma. A familia tradicional é caracterizada por uma autoridade patriarcal com objetivo de transmissão de patrimônio. A família moderna, presente entres os séculos XVIII e XX, é fundada no amor romântico e na reciprocidade afetiva, na qual o filho aparece como responsabilidade dos pais e do Estado. Por fim, a família "pósmoderna", que surge partir da década de 1960, define-se como uma relação entre dois indivíduos que buscam relações íntimas ou realização sexual (Zornig, 2010).

No que diz respeito aos estudos acerca da vivência concreta de cada um dos atores envolvidos neste processo de transição para a parentalidade, é possível observar na literatura científica que sempre foi dado um maior destaque para as pesquisas sobre a maternidade ou sobre a díade mãe-filho, havendo estudos em menor número sobre a figura do pai (Costa \& Rossetti-Ferreira, 2009a, 2009b; Levandowski, 2001; Levandowski \& Piccinini, 2004) e suas experiências no contexto familiar. Desse modo, ao considerar que, quando nasce um bebê, não apenas um filho vem ao mundo, mas também surgem um pai e uma mãe, na Psicologia do Desenvolvimento diversas perspectivas teóricas têm apontado para a necessidade de investigar os diferentes atores 
envolvidos neste processo (Cecîlio \& Scorsolini-Comin, 2013; Rossetti-Ferreira \& Costa, 2012), dentre os quais, neste estudo destacamos os pais de meia-idade.

\subsection{Paternidade em tempos de mudanças: Contextualizando a paternidade na contemporaneidade}

O conceito de paternidade e sua vivência concreta têm sido alvos de debates desde o final do século XIX, no entanto, foi apenas a partir do início dos anos 1970 que se verificou uma investigação mais intensa e sistemática acerca da temática (Balancho, 2004; Lamb, 2000). As transformações sociais que vêm ocorrendo nos espaços público e privado, sobretudo a partir da década de 1960, são consideradas por diversos estudiosos como marco inicial de significativas mudanças socioculturais no que diz respeito às concepções de masculinidade e feminilidade, seus desdobramentos no desempenho das funções de homens e mulheres na sociedade e também no interior da família (Freitas et al., 2009).

O surgimento de um novo modelo econômico industrial e a inserção maciça das mulheres no mercado de trabalho, conquistando a independência econômica, em busca por igualdade de direitos e deveres com os homens, possibilitou o questionamento das posições e funções sociais, bem como o surgimento de novos arranjos familiares (Gomes \& Resende, 2004; Moraes, 2001).

Inseridas no mundo do trabalho, as mulheres deixaram de dedicar-se exclusivamente à casa e à família, o que fez emergir a exigência de um pai mais envolvido com seus filhos (J. H. Pleck \& E. H. Pleck, 1997, Hennigen, 2010), ocupando assim o espaço privado de forma mais efetiva, envolvendo-se no cuidado dos filhos e nas tarefas domésticas (Bandeira, Goetz, Vieira, \& Pontes, 2005; Staudt \& Wagner, 2008). Nesse contexto em transformação, os estudos sobre a masculinidade ganharam espaço e possibilitaram a reflexão sobre a condição masculina, questionando as imposições do modelo hegemônico e procurando outras formas dos homens se socializarem e se relacionarem com o sexo oposto e com seus filhos (Vieira \& Souza, 2010).

No bojo desses estudos e reflexões, observa-se a paternidade com um construto crucial em Psicologia, em que se entende que as mudanças incrementais na família e na sociedade impuseram inevitáveis transformações, o que fez despontar a noção de "um novo pai' presente na contemporaneidade (Balancho; 2004; Belo \& Macedo, 1996; Gottman \& DeClaire, 1997; Vieira \& Souza, 2010). Para diversos estudiosos, este "novo 
pai" caracteriza-se por ser mais presente e identificado com as exigências contemporâneas da familia, baseando-se em uma maior aproximação afetiva com seus filhos, de modo oposto à concepção tradicional, que exigia distanciamento físico e afetivo (Balancho, 2004; Gomes \& Resende 2004; Vieira \& Souza, 2010).

J. H. Pleck e E. H. Pleck (1997) denominam esse novo modelo de paternidade de pai cogenitor, do qual se espera o auxilio à mãe nos cuidados físicos e diários, na educação e o envolvimento e a participação no desenvolvimento dos filhos, desde o nascimento até a fase adulta. Assim, o pai, antes considerado somente o provedor do sustento do filho, começa a ser chamado na contemporaneidade para exercer mais ativamente suas funções. Com isso, o modelo de familia tradicional, no qual o pai é o nível mais alto de hierarquia, começa a dar lugar a um pai mais sensível, íntimo, participativo e envolvido na criação dos filhos, que apresenta como diferencial o envolvimento afetivo (Gomes \& Resende 2004; Vieira \& Souza, 2010).

Nessa perspectiva, destaca-se que, ainda que o pai não desempenhe necessariamente todas as tarefas de maneira igualitária com a mãe, espera-se que ele cuide, brinque, instrua e demonstre afeto e amizade, tornando-se um pai com funções múltiplas, mais participativo e envolvido no desenvolvimento de seus filhos (Bandeira et al, 2005), possibilitando assim, que as relações de autoridade vão dando espaço, ainda que de forma gradativa, às relações permeadas por afeto e negociações, de forma que a paternidade contribua para a ruptura de estereótipos de uma masculinidade insensível e intocável (Freitas et al., 2009).

Desse modo, é possível observar que o exercício da paternidade envolve e proporciona o desenvolvimento de práticas e habilidades de cuidados com os filhos (Meincke \& Carraro, 2009) e, ao se pensar na perspectiva da relação pai e filho, Lamb, Pleck, Charnov e Levine (1987) propõem o constructo do envolvimento paterno, dividindo-o em três dimensões: (a) a acessibilidade, caracterizada pela presença ou disponibilidade potencial do pai para interagir com a criança; (b) a responsabilidade, papel que o pai desempenha assegurando cuidados e recursos para a criança, e (c) o engajamento, que diz respeito à experiência do pai no contato direto com o filho, por meio do cuidado e outras atividades compartilhadas.

A respeito das mudanças no exercício da paternidade, de modo geral, Lewis e Dessen (1999) sugerem que essas transformações podem ser analisadas a partir de três perspectivas: tradicional; moderna e emergente. No primeiro caso, destaca-se como principais características do papel paterno o ser provedor e disciplinador, sendo seu 
envolvimento com os filhos considerado restrito. $\mathrm{Na}$ segunda perspectiva, a função do pai está relacionada com o desenvolvimento moral, acadêmico e emocional dos filhos. $\mathrm{Na}$ terceira perspectiva, que corresponde ao modelo de paternidade emergente, o pai participa efetivamente das atividades domésticas e tem envolvimento ativo em várias esferas do cuidado e da educação doméstica dos filhos.

Para Badinter (1972), esse perfil de novo pai, que foi se esboçando gradativamente no decorrer do tempo:

É um homem oriundo das classes médias ou altas, que se beneficia de uma formação e de uma renda mais elevada que a média. Tem uma profissão liberal que the permite, bem como à sua mulher, dispor livremente de seu tempo e rejeita a cultura masculina tradicional. Finalmente, vivem com mulheres que não têm vontade de ser mães em tempo integral (p. 172).

Nos estudos de Balancho (2004), os pais e os avós entrevistados apoiam tal visão de que se instaurou uma mudança significativa no exercício paterno, considerando a existência de uma clara transformação na forma de definir, conceitualizar e descrever o pai nas duas últimas gerações. Ainda que o tempo de envolvimento e o grau de responsabilidade para com os filhos não tenham sido avaliados no referido estudo, a perspectiva e concepção detectadas em todos os entrevistados eram de que havia uma mudança qualitativa, caminhando no sentido da caracterização do pai atual ser percebido como mais sensível, mais presente, mais próximo afetivamente dos filhos e também mais compreensivo.

Freitas, Coelho e Silva (2007) verificaram, a partir de seus estudos, que os pais cujo posicionamento se aproxima mais do modelo tradicional entendem que a paternidade se inicia com o nascimento da criança. Ao sustentar esse ideário, esses homens via de regra distanciam-se de suas companheiras durante toda a gestação. Por outro lado, os pais que se aproximam da nova concepção veem a gravidez como o início da paternidade, envolvendo-se emocionalmente com o filho antes mesmo de ele nascer (Oliveira \& Silva, 2011).

O modo distinto como cada homem reage diante da paternidade potencial e/ou vivencial pode ser entendido ainda a partir de sua organização psíquica e dos inúmeros determinantes socioculturais, econômicos e históricos que atravessam o exercício da paternidade na cultura ocidental, o que indica que cada um engendra um modo singular 
de ser pai, com potencialidades e limitações particulares (Oliveira \& Silva, 2011; Tarnowski, Próspero, \& Elsen, 2005). Além disso, D. W. Shwalb e B. J. Shwalb (2014) ressaltam que os papéis desempenhados pelos pais são altamente variáveis e dependentes do contexto cultural, o que faz com que o excesso de generalizações acerca da paternidade seja perigoso, tornando fundamental que as práticas paternas em cada sociedade sejam vistas dentro de um contexto específico e mutável, que sofre influências da localização geográfica, dos legados históricos, das heranças culturais, das características da familia, de fatores econômicos, das condições de trabalho, das normas e valores compartilhados, de grupos étnicos e de padrões de imigração e migração. Desse modo, é necessário que os estudos sejam culturalmente sensíveis às nuances e matizes próprias de cada contexto.

Dessa forma, questões emocionais, culturais, religiosas e familiares permearão a vivência da paternidade como experiência desejável ou não desejável, ditando como será estabelecida a relação entre homem-mulher e com o(a) filho(a), quando se pensa em uma familia constituída por meio do vínculo de pais heterossexuais (a paternidade vivenciada pelo casal constituído por dois homens não será objeto do presente estudo). Em meio às múltiplas dimensões que compõem o fenômeno ser pai, podem-se destacar as visões distintas acerca da maneira como o homem vivencia o "tornar-se pai", e a forma como isso influencia e modula sua relação direta com o filho. De acordo com Freitas et al., (2007), a experiência da paternidade depende da relação vivida entre pai e filho no passado, que vai influenciar o modo como o homem compreende e assume a sua masculinidade. Para sua realização como pai, ele buscará referências em seu próprio pai e, ao encontrá-las, na maioria das vezes trata-se do modelo de pai distante e pouco envolvido afetivamente, referencial de masculinidade ainda hegemônico. Assim, o filho tende a incorporar esse modelo, constituindo uma subjetividade distanciada da valorização do afeto nos relacionamentos, ao mesmo tempo em que tem na sua mãe o exemplo máximo de cuidado. Reproduz-se, portanto, a relação pai-mãe-filho, tal como determinada socialmente e experimentada na sua própria vivência, evidenciando um mecanismo ideológico de reprodução do conservadorismo, que irá perpetuar ou pelo menos contribuir para a manutenção do status quo.

Gomes e Resende (2004) também destacam que tal vivência depende dessa experiência, mas lembram que "o ser pai" atualiza no homem conflitos em relação à sua própria figura paterna, de maneira que, ao sentirem seus pais como distantes, por exemplo, desejem se tornar pais diferentes. Para esses autores, é no cerne dos sentimentos 
paternos de cada homem e na rede de relações estabelecidas com o pai real ou imaginário que se tornam possíveis a construção e reconstrução da sua subjetividade de pai.

Costa e Rossetti-Ferreira (2007) e Gabriel e Dias (2011) concordam que a paternidade consiste tanto em um movimento prenhe de novos sentidos, transformações e responsabilidades, quanto no ressurgimento e reavaliação das experiências vividas com os próprios pais. É nesse sentido que, para Gabriel e Dias (2011), o homem, ao se constituir como pai, (re)avalia a relação vivida com o próprio pai, mas não deixa de questionar essas concepções dadas a priori, tomando para si tanto o modelo vivenciado de paternagem como o modelo de como um bom pai deve ser, cultivado no seu próprio imaginário. Ao tomar essa atitude, concebe uma nova e singular maneira de ser pai, baseando-se no que está vivenciando no momento - sentimentos, preocupações, expectativas, dúvidas, desejos - e nos espaços que estão sendo abertos para que ele exerça sua paternidade de modo confortável e único.

Cabe ressaltar ainda que, embora as transformações sociais repercutam na concepção de paternidade sustentadas em cada época, subsistem ainda no imaginário social marcas da estrutura tradicional. Ou seja, há rupturas, mas também permanências dos modelos herdados. Se, de um lado, exigências sociais operam pulverizando a figura do provedor responsável pela reprodução material da organização familiar, de outro, as familias buscam se organizar, formando casais de dupla renda ou de dupla carreira (Gomes \& Resende, 2004). Nesse sentido, as vivências de paternidade ora se ancoram no modelo de pai tradicional, ora apontam para a perspectiva de um novo modelo de ser pai: o "novo pai", que visita o pai tradicional, mas dele se afasta, dotando a paternidade de sentido mais amplo (Freitas et al., 2007). Isso nos permite falar em paternidades no plural, pois tal concepção envolve rupturas e continuidades com o modelo tradicional, o que faz com que as suas formas de vivenciar e representar a paternidade estejam presentes de maneira concomitante e no mesmo lugar por diferentes homens, bem como em distintos momentos e lugares pelo mesmo homem, na busca de melhor cumprir o que supõe ser o essencial ao desenvolvimento dos filhos (Dantas, Jablonski, \& FéresCarneiro, 2004; Freitas et al., 2007; Gomes \& Resende, 2004; Oliveira \& Silva, 2011; Perucchi \& Beirão, 2007; Thurler, 2006; Vieira \& Souza, 2010).

A esse respeito, os resultados de uma revisão de literatura realizada por Vieira et al. (2014) indicam que, mesmo que os homens vivenciem um processo de transição em que se mescla o modelo do pai tradicional e outro mais atual, de modo geral os genitores masculinos ainda concebem a paternidade como encargo social fortemente vinculado à 
função de provedor material e moral da família, evidenciando a existência de um notável desequilibrio entre homens e mulheres no que se refere à participação nos afazeres de casa e nas tarefas de cuidado da prole.

Além do mais, deve-se considerar que, em meio a essa ressignificação de experiências e busca por maior aproximação afetiva dos filhos, existe a preocupação em relação a saber se essa nova postura pode ou não interferir na manutenção da masculinidade, o que contribui para que muitos homens encontrem-se em um dilema entre o engajamento com aquilo que lhe está sendo solicitado para acompanhar as transformações contemporâneas e, ao mesmo tempo, receosos em não comprometer sua imagem de virilidade e de macho diante da sociedade que, por vezes, ainda estimula e valoriza tais características, fortemente alicerçadas nos estereótipos de gênero (Staudt \& Wagner, 2008).

Sem contar que ainda se observa a vinculação da maternidade a uma aura idealizada, diferenciada em relação à paternidade (Cúnico \& Arpini, 2013), uma vez que, nas sociedades ocidentais, são correntes os discursos sobre a existência de um suposto instinto materno, o qual tornaria a mulher naturalmente predisposta para exercer os cuidados infantis. Embora estudos já tenham demonstrado que não há natureza biológica que determine a mulher como sendo necessariamente mais apta para cuidar e proteger a prole, a defesa do instinto materno ainda tem bastante força, o que pode ser verificado facilmente no contexto social (Sousa, 2010).

Conforme Hurstel (1999), o entendimento que comumente se tem sobre mães serem essenciais nos cuidados com os filhos se constituiu a partir de três causas fundamentais, que contribuem para a fragilização da imagem do pai, a saber: (1) contexto social, no qual instituições de atendimentos a crianças privilegiam exclusivamente a figura da mãe, perpetuando a ideia de que somente ela tem a expertise no papel de cuidadora; (2) discursos ideológicos, ou seja, a argumentação de que cuidar adequadamente de crianças seria uma característica inata às mulheres e, (3) causas legais, as quais dão preferência à mãe no que diz respeito aos cuidados com a prole, restando ao pai apenas um papel secundário.

Como salienta Muzio (1998), é preciso compreender que ser mãe e pai implicam apropriar-se de um papel social construído historicamente. A assimilação, bem como a diferenciação entre esses papeis, ocorre já no processo de socialização inicial de homens e mulheres, em que estas últimas são ensinadas desde muito cedo a serem cuidadoras, enquanto que ao menino é ensinado que brincar de boneca é coisa de menina, não the 
sendo dada a oportunidade de treinar para ser pai. Assim, ser pai, segundo a autora, não faz parte da identidade masculina; a paternidade é uma função que poderá the ser adicionada. De forma semelhante, Romanelli (2003) assinala que, na construção social das identidades de gênero, homens e mulheres recebem orientações diferentes, sendo os meninos preparados por seus pais para serem provedores, enquanto as meninas são mais vigiadas e ensinadas a cuidar dos outros e do lar.

No entanto, ainda se observam discursos que defendem a existência inconteste de um instinto materno, que se encontram entrelaçados a outras narrativas que dizem respeito à figura paterna e aos filhos. Ambos afetam-se mutuamente, repercutindo sobre o exercício dos papeis e das relações parentais, o que faz com que muitos pais ainda acreditem na maior importância da relação mãe-filho para o processo de desenvolvimento, o que acaba por perpetuar certa resistência por parte das mães em abrir mão do "monopólio da maternidade" (Borsa \& Nunes, 2011), o que contribui para afastálas de uma relação mais igualitária entre os gêneros.

Em meio à consideração desses vários aspectos que permeiam a paternidade, a única certeza que se tem é que o modelo parental e a divisão de tarefas baseada nos gêneros não definem totalmente a demanda das novas famílias (Monteiro, Verissimo, Santos, \& Vaughn, 2008; Pimenta, Veríssimo, Monteiro, \& Costa, 2010). Assim, de modo geral, pode-se considerar que, dentre os desafios prementes de homens e de mulheres, está a reinvenção e redefinição do lugar do pai no contexto familiar (Bornholdt, Wagner, \& Staudt, 2007), o que reitera a necessidade de realizar investigações que se dediquem a tal temática (Cecilio \& Scorsolini-Comin, 2013; Rossetti-Ferreira \& Costa, 2012) e de considerar os diversos arranjos familiares presentes na atualidade, dentre os quais este estudo acrescenta a preocupação com a singularidade da vivência paterna na meia-idade.

\subsection{Concepções sobre a meia-idade: Articulações com a temática paternidade}

A meia-idade é uma etapa do ciclo vital que constitui um tema recente e ainda pouco explorado pela literatura, configurando, assim, uma lacuna de conhecimento nos diferentes campos do saber, o que contrasta com o crescente e intenso interesse científico pelos estudos acerca do envelhecimento humano após os 60 anos e com produção científica já consolidada acerca da temática da infância (Antunes \& Silva, 2013; Oliveira, 2004). Destaca-se ainda que, quando tratado, tal tema por vezes tem recebido definições 
baseadas exclusivamente em determinantes e marcos cronológicos, como é o caso dos Descritores da Saúde (DeCS), sendo definida como a etapa do ciclo vital que abrange dos 45 aos 64 anos (Antunes \& Silva, 2013). De acordo com os referidos autores, é preciso levar em conta, quando toma-se a periodização da vida em categorias de idade, a nãonaturalidade das categorias etárias e a concepção de que elas são construções históricas e sociais, o que não significa negar o ciclo biológico da vida, mas considerar como cada momento deste ciclo é vivenciado simbolicamente ao longo da história e em diferentes culturas e sociedades. Compreende-se, no presente estudo, a impossibilidade de conceber os diversos estágios da vida como fases homogêneas, uma vez que vivemos uma intensa pluralização dos estilos de vida e diferentes formas de viver no interior de uma mesma fase da vida, o que nos permite falar, assim como na paternidade, em infâncias, juventudes e velhices, sempre no plural (Arroyo, 2004).

Desse modo, destaca-se que, para além de uma concepção linear e inflexível, o estudo de determinada fase do ciclo vital - meia-idade - compreende as múltiplas formas de vivê-la e significa-la (Oliveira, 2004). Quando se buscam circunscrever algumas de suas características e especificidades, a partir da literatura, objetiva-se tão-somente alcançar uma compreensão mais próxima dessa fase vital, distinguindo-a das demais e tomando a paternidade na meia-idade como alvo de interesse e investigação, possibilitando, assim, trazer à tona a perspectiva de quem de fato vivencia tal etapa.

Erik Erikson (1976a), à luz da psicanálise e do movimento culturalista, estudou o processo de desenvolvimento do ser humano desde seu nascimento até o final de sua existência, definindo, desse modo, de acordo com as realizações sociais a serem vivenciadas nesse processo, oito ciclos pelos quais a pessoa passaria ao longo de seu desenvolvimento: (1) confiança básica versus desconfiança básica; (2) autonomia versus vergonha e dúvida; (3) iniciativa versus culpa, (4) indústria versus inferioridade, (5) identidade versus confusão de papel; (6) intimidade versus isolamento; (7) generatividade versus estagnação e, (8) integridade versus desesperança.

Dentre esses diversos dilemas que acompanham o processo de evolução e diferenciação da personalidade pode ser destacado o sétimo, que corresponde à faixa etária da meia-idade, envolvendo a necessidade de que os seres humanos maduros, que já viveram diversas experiências, têm de transmitir aos mais jovens o que aprenderam e experenciaram, o que corresponde à generatividade. Dessa maneira, em condições ideais, o ser humano preocupa-se e dedica-se ao cuidado daquilo que gerou, o que é visível na transmissão de valores de pai para filho. Ao mesmo tempo, destaca-se que, nesse período 
evolutivo, muitas pessoas podem ter uma sensação de que, ao envelhecerem, podem vir a ser considerados ultrapassados, que nada mais têm a acrescentar ao mundo e, assim, sentirem-se estagnados (Erikson, 1976a).

Por ser um momento de profundas mudanças físicas e psicológicas, a meia-idade pode vir a ser uma fase em que o indivíduo se abre para a possibilidade de ressignificar seu modo de ser, mas pode ser também uma etapa em que a pessoa não vislumbra novas possibilidades existenciais, sendo tomada por um sentimento de desesperança (Erikson, 1976b). Tal fase, denominada ainda de maturidade, caracteriza-se por ser um momento que envolve um processo de mudança e transição de um período mais produtivo para outro de elaboração das experiências vividas, podendo despertar sentimentos de ambivalência, uma vez que a pessoa sente sua vitalidade, ao mesmo tempo em que percebe alterações físicas e psíquicas decorrentes do processo de envelhecimento (Trindade, 2002).

No que tange à sexualidade, o homem na meia-idade apresentará algumas mudanças relacionadas ao funcionamento de seus órgãos sexuais. Um desses acontecimentos refere-se às ereções, que não se apresentam de modo tão rápido e fácil como na juventude, e que podem se manifestar menos rígidas (Trindade, 2002). Redução da energia física, cansaço, fadiga e diminuição da força e falta de condicionamento físico também são vistas como perdas que se iniciam nessa etapa do ciclo vital (Antunes \& Silva, 2013), enquanto que, por outro lado, experiência de vida e aprendizados obtidos ao longo da trajetória da existência são considerados ganhos, revelando, assim, um caráter ambivalente de tal fase evolutiva (Jorge, 2005).

Características como rotina, seriedade e formalismo podem ser destacadas como aquelas que permeiam a noção de trabalho como atividade principal da meia-idade, sendo seguidas pela expectativa de estabilidade financeira e efetivação ou proximidade da aposentadoria. Com relação a esses aspectos, considera-se que uma das especificidades da meia-idade é a ideia de pico ou auge no emprego, em virtude dos anos de experiência dentro de uma mesma função. No que tange às relações sociais e familiares, na meiaidade haveria uma tendência à restrição dos laços sociais e uma atribuição de maior importância às relações significativas (Kovács, 2010). No âmbito familiar, comumente se observa a realidade dos filhos já criados e saindo de casa, e a existência do casamento de longa duração (Jorge, 2005).

A meia-idade é caracterizada ainda como um período do desenvolvimento em que ocorreria uma espécie de colapso, muitas vezes denominado de "crise da meia-idade". De 
acordo com Trindade (2002), tal crise comporta uma série de sentimentos e comportamentos, que parecem estar vinculados à concepção de homem, presente tanto no nível individual como social. Toma forma, gradualmente, a conscientização da brevidade da vida e de que é inevitável palmilhar um percurso que um dia há de desembocar na finitude. À medida que as novas limitações físicas e importantes mudanças nos principais papéis desempenhados até então vão sendo reconhecidas (Kovács, 2010), essas vivências podem desencadear profundos sentimentos de angústia e medo, além de despertar em muitos homens a fuga da possibilidade de questionar ou avaliar como vivenciou sua vida até aquele momento (Trindade, 2002).

$\mathrm{O}$ receio de envelhecer e se tornar improdutivo, inválido ou impotente, pode revelar-se fortemente nessa fase, estando relacionado ao modo como a constituição subjetiva do homem ocorreu e ainda ocorre - vinculada à produção, capacidade de controle do corpo e das pessoas, distância emocional dos acontecimentos e aos valores enaltecidos em nossa cultura de hipervalorização da juventude, aliada à desvalorização do envelhecimento (Trindade, 2002).

No que tange à vivência paterna na meia-idade, observa-se notável escassez de estudos na literatura científica, embora diversas transformações - tais como o aumento da expectativa de vida e o crescente índice de casamento e de paternidade de homens em idade mais avançadas - sinalizem a importância de estudar tal vivência (Nogueira \& Ribeiro, 2013).

Os resultados do estudo de revisão de literatura realizado por Souza e Benetti (2009), cujo objetivo foi verificar a incidência de artigos internacionais e nacionais sobre o tema paternidade no período de 2000 a 2007, realizado a partir análise de 353 artigos, apontaram para uma significativa produção internacional e nacional acerca da temática. No entanto, no que diz respeito à compreensão da vivência paterna a partir de diferentes etapas do ciclo vital, do total de 104 artigos analisados, 45 tratavam da paternidade no contexto da adolescência e 59 abordavam a paternidade em relação à idade adulta, não sendo encontrado nenhum estudo que retratasse a vivência paterna na meia-idade.

Dentre os poucos estudos, pode-se destacar a pesquisa realizada por Trindade (2002) com homens na meia-idade, na qual a autora explorou os eixos da paternidade, sexualidade e projetos de vida de seus participantes, com enfoque em homens casados e pais de filhos adolescentes. O estudo permitiu desvelar diversas contribuições dessa vivência, dentre as quais destaca-se a preocupação relacionada à educação e crescimento 
dos filhos e inquietações relacionadas ao consumo de álcool, drogas, bem como à esfera da sexualidade.

No estudo de Silva e Silva (2014), cujo objetivo foi investigar as necessidades e preocupações de pais que se encontravam em diferentes etapas do ciclo vital, relatos de cinco pais de meia-idade, também denominada idade madura, revelaram preocupações e necessidades relacionadas ao mundo do trabalho e ao cuidado e futuro dos filhos. A iminência da aposentadoria foi destacada pelos participantes como uma ameaça à estabilidade da família, em que o fato de não se contar com uma renda familiar mensal fez com que um dos participantes sentisse dificuldades para prover as necessidades do filho, priorizando a busca da subsistência da familia e colocando em primeiro lugar a satisfação das necessidades do filho, por meio de serviços informais. No relato dos outros três participantes, com emprego formal, estes reconheceram que participaram pouco dos cuidados básicos dos filhos quando eles eram pequenos, uma vez que, na época, suas companheiras não trabalhavam e assumiram integralmente tal responsabilidade. No entanto, apesar de não realizarem tarefas básicas de cuidado parental, consideram que sempre proporcionaram aos filhos bens materiais, possibilitando que sua companheira desenvolvesse o papel de cuidadora do lar e dos filhos (Silva \& Silva, 2014).

A educação e saúde dos filhos também foram preocupações referidas por todos os pais em idade madura, em especial, em um dos participantes, que assumiu o cuidado do filho pequeno após a separação da companheira, demonstrando, assim, preocupação em conciliar o cuidado da criança com a provisão do sustento da casa e o acompanhamento do desenvolvimento do filho. Quatro participantes relataram ter uma relação com os filhos baseada, principalmente, no diálogo e confiança, procurando mostrar-lhes o que é certo e o que é errado. Entretanto, demonstraram dificuldades em conviver com os valores e regras impostas pelo mundo contemporâneo, sentindo-se impotentes diante da influência de outros contextos e das interações estabelecidas com outros indivíduos (Silva \& Silva, 2014).

Em estudo realizado por Colleti e Scorsolini-Comin (2015) com quatro homens que se tornaram pais pela primeira vez durante a meia-idade, os discursos dos participantes revelaram que as características e mudanças ocorridas nessa fase do ciclo vital, por vezes vinham à tona não só com suas percepções do próprio corpo e de seus sentimentos, mas também no exercício da função paterna e diante das exigências que esse papel apresenta. Desse modo, a conscientização acerca da finitude pareceu ficar ainda mais forte e dolorosa quando os participantes refletiam sobre a idade dos seus filhos, ao 
passo que aspectos considerados positivos da vivência paterna - como, por exemplo, a maturidade -, também pareciam se referir a percepções e mudanças relacionadas à fase do ciclo vital em que se encontravam.

\subsection{Marco teórico-conceitual}

Dentre as diversas abordagens teóricas que têm se dedicado à investigação da temática investigada, a Psicanálise emerge como uma corrente que tem investido na elucidação das questões relacionadas à paternidade e à parentalidade. As contribuições oriundas da psicanálise de casal e de família são particularmente férteis nesse campo (Berttran \& Gomes, 2013; Gomes \& Zanetti, 2008; Zanetti \& Gomes, 2012), colocando em destaque os sistemas e redes de comunicação, de identificação e de fantasias intra, inter e transubjetivas produzidas no contexto das relações familiares. Assim, falar em pais, mães, filhos e filhas envolve também tratar do modo como o ser humano foi se constituindo ao longo das diferentes gerações. Ainda que o estudo da transmissão psíquica não esteja definido entre os objetivos desta investigação, trata-se de um conceito que permeia a paternidade e contribui, por exemplo, para a compreensão de que modo o modelo de pai introjetado pelo filho pode influenciar o modo como os homens constroem e vivenciam o exercício de sua paternidade, o que justifica abordá-la.

Alguns estudos levaram à formulação de uma teoria vincular e das identificações da perspectiva psicanalítica da família, dos quais, na presente investigação, priorizaremos a matriz francesa, cujos principais expoentes são Kaës, Eiguer, Rufiot e Benghozi, Em sua vertente, Kaës (1998) destaca que as representações entre as gerações têm também a função de organizar a escolha de objeto dos parceiros, o que se relaciona ao tipo de familia que se deseja fundar e à educação mais alinhada ao ideal familiar. Para este autor, orientado por uma concepção de inconsciente compartilhado, todo grupo humano resulta de uma tópica subjetiva, projetada pelos próprios membros. Na visão de Kaës (2001), a transmissão ocorreria de uma geração a outra (intergeracional) a partir de um espaço no qual são realizadas as vivências psíquicas do grupo familiar, no qual a história familiar é constituída e reconhecida, e onde são criados os mitos que passam para as gerações posteriores. Outro tipo de transmissão mencionada por Kaës é a transpsíquica, que se dá a partir dos psiquismos dos outros membros da família, ou seja, dá-se fora do sujeito.

Aquilo que se transmite é o que não pode ser contido, retido, aquilo que não é lembrado, o que não encontra inscrição na psique dos pais e vem depositar-se ou 
enquistar-se na psique de uma criança: a falta, a doença, o crime, os objetos desaparecidos sem traço nem memória; para os quais um trabalho de luto não pode ser realizado (Kaës, 2005, p. 128). Esse posicionamento também é partilhado por Benghozi (2010), segundo o qual a transmissão do negativo se dá a partir daquilo que não é simbolizado nem metabolizado de uma geração a outra, podendo ser expresso por meio de sintomas. O impensável, inominável, indizível e o inconfessável familiar seriam indutores da transmissão transgeracional do negativo. No entanto, pela leitura de Gomes (2006), transmitir-se-iam também aspectos positivos e adaptativos, como os que amparam e asseguram as continuidades narcísicas, a manutenção dos vínculos intersubjetivos, a tendência à conservação e à preservação das formas de vida, entre outros aspectos transformadores, criativos e de proteção do psiquismo.

Kaës (2005) distingue ainda duas modalidades de transmissão psíquica: a transmissão sem transformação ou transmissão-repetição e a transmissão transicional e fantasias de transição. Em suma, tem-se que na primeira modalidade a transmissão é direta, passando sem transformação de um sujeito para o outro ou mais de um outro. No segundo caso, a transicionalidade permite que as histórias do sujeito, que ele recebe sem saber, sejam por ele reinventadas, encontradas e criadas, permitindo que ele anuncie as coisas transmitidas e as representações da transmissão, ainda que em uma posição de defesa.

Para Eiguer (1995), a vida familiar pode ser compreendida a partir de três organizadores responsáveis pela estruturação da vida psíquica: a escolha do objeto, o eu familiar e os fantasmas partilhados. O primeiro organizador atua no momento da escolha do parceiro, que é feita a partir do modelo identificatório de cada um dos cônjuges, o que remontaria à construção de suas primeiras vinculações na infância. $O$ segundo organizador corresponde ao investimento libidinal de cada membro da família, constituindo o que se denomina mundo familiar, que corresponde aos sentimentos de pertença ao grupo que permitem compreendê-lo como uma continuidade, definindo o que pode e o que não pode fazer parte desse domínio. O terceiro organizador se refere ao processo de interfantasmatização, que destaca o desenvolvimento de um espaço transicional de intercâmbios, humor, criatividade e de relatos de histórias pessoais e de seus ancestrais, retomando o papel das fantasias no processo de construção das identificações no campo da intersubjetividade (Eiguer, 1985; Lisboa \& Féres-Carneiro, 2005; Magalhães \& Féres-Carneiro, 2004). 
Pierre Benghozi (2010), em sua abordagem, também faz uso da distinção entre transmissão intergeracional e transmissão transgeracional. $\mathrm{Na}$ primeira modalidade, $\mathrm{o}$ patrimônio psíquico familiar seria recebido por uma geração, memorizado, historicizado, transformado, elaborado e transmitido à nova geração. Já na segunda modalidade, o material psíquico familiar seria transmitido sem ter sido transformado ou metabolizado, ou seja, em estado bruto. Para este autor, o Vínculo é considerado a base da transmissão psíquica e, para explicar como ocorre esse processo de uma geração a outra, Benghozi emprega a metáfora de uma rede. Nesta, a malha é a disposição dos Vínculos, sendo construída por um conjunto que liga Vínculos de filiação e de afiliação. A malhagem é o trabalho psíquico de construção-desconstrução e de organização dos Vínculos.

Os Vínculos de filiação remontam aos ascendentes e conduzem aos descendentes, uma vez que correspondem aos vínculos grupais de pertencimento. Segundo Benghozi (2010), o Vìnculo de filiação é uma construção psíquica apoiada na base do real biológico de filiação, enquanto que, o Vínculo de afiliação diz respeito ao Vínculo de aliança conjugal, assim como qualquer Vínculo que determine o pertencimento a um grupo, uma instituição, uma comunidade.

O que deve ser destacado na tese de Benghozi (2010) é a possibilidade sempre aberta de que ocorra a remalhagem, ou seja, a reconstrução da rede de Vínculos de filiação e de afiliação. Assim, filiativo e afiliativo são repensados em termos de dinâmica de malhagem, desmalhagem e remalhagem, não como Vínculos radicalmente dissociados entre si, mas como Vínculos suscetíveis de serem interconectados para formar um espaço psíquico novo, o da malha.

Outro destaque da obra de Benghozi (2005) é a possibilidade de transformação dos vínculos afetivos a partir do trabalho psíquico de remalhagem e desmalhagem. $\mathrm{O}$ continente grupal familiar seria uma malhagem de Vínculos de filiação e de afiliação que poderiam se transformar e se reconfigurar constantemente, gerando novos arranjos e novos entrelaçamentos. Nesse ponto, Benghozi (2010) enfatiza que o Vínculo afiliativo parece estar, cada vez mais tomando o lugar do Vínculo filiativo, ou seja, a transmissão psíquica não deveria ser olhada tanto a partir dos vínculos de filiação pais e filhos(as), mães e filhos(as), mas também a partir dos laços conjugais estabelecidos e das transformações mobilizadas a partir das instituições das quais fazemos parte no espaço social. Olhada desse modo, a familia não se resumiria às heranças transmitidas ao nascimento, mas também abarcaria os processos de transformação dessa malha inicial. $\mathrm{O}$ 
continente grupal familiar estaria sempre aberto a novas configurações, podendo se aliar a outros continentes grupais familiares.

Com base nessa leitura, pode-se destacar que, assim como a transmissão psíquica não pode ser "barrada", pois ocorre em nível grupal inconsciente, também as possibilidades de reconfiguração desses vínculos transmitidos não podem ser desconsideradas (Benghozi, 2010, p. 258). Assim, a partir desta perspectiva, a paternidade na meia-idade pode ser compreendida como composta por múltiplas articulações, construída a partir das referências das quais os pais são herdeiros, mas também permanece aberta a (re)criações, o que pode ser observado no estudo de Colleti e Scorsolini-Comin (2015), no qual se observou que as vivências em relação ao genitor na assunção da paternidade foram colocadas em evidência pelos participantes, mas não como determinantes desse processo, uma vez que os desafios e características da meia-idade e o porvir das relações sociais, familiares e conjugais que caracterizam essa fase do ciclo vital também emergiram como aspectos significativos para a construção da paternidade nos participantes do estudo.

\section{JUSTIFICATIVA}

Atualmente, o conceito de paternidade tem recebido diversas contribuições de estudos advindos de áreas tão diversas como a Psicologia, Sociologia, Antropologia, Direito, Serviço Social e também das áreas diretamente relacionadas à saúde, como a Genética, representando assim um campo crescente de investigação, notadamente na Psicologia, em que se destaca a importância de conhecer e compreender o lugar que o pai tem ocupado na contemporaneidade (Borsa \& Nunes, 2011; Luz \& Berni, 2010; Parke, 1998; Silva \& Piccinini, 2007). No entanto, apesar dessa ampla discussão acerca da concepção de paternidade na contemporaneidade, em que se apregoa o surgimento de um "novo pai” (Gomes \& Resende 2004; Vieira \& Souza, 2010), no que diz respeito a compreensão da paternidade em diferentes fases do ciclo vital os poucos estudos existentes se concentra na experiência de adolescentes e no vínculo destes com suas companheiras e filhos (Silva \& Silva, 2014), com poucas referências a homens na meiaidade (Colleti \& Scorsolini-Comin, 2015; Trindade, 2002).

$\mathrm{Na}$ área da Psicologia do Desenvolvimento, cada vez mais se tem uma compreensão de que os processos de mudanças ocorrem em todo o ciclo vital, de modo que a dinâmica de transição para a parentalidade acaba sendo um movimento de intensa 
transformação, qualquer que seja o período do desenvolvimento em que o pai se encontra, pois envolve a assunção de um novo papel e de novos atributos relacionados ao ser pai. Mais recentemente, na Psicologia do Desenvolvimento tem havido um movimento de se investigar o período que vem a ser considerado o da meia-idade e suas características.

A meia-idade é considerada uma fase de transição do mundo adulto para o período do envelhecimento, recobrindo uma ampla gama de características, desafios e potencialidades, dentre os quais se destacam: as alterações físicas, em que não só se constata uma diminuição da resistência e da energia física, como se verificam mudanças menos evidentes, como é o caso da regulação hormonal masculina, com a redução na secreção da hormona testicular (Antunes \& Silva, 2013; Ribeiro, 2005, Trindade, 2002), a tendência a estar profissionalmente estável, a limitação dos contatos sociais, em que há um aumento da proximidade emocional em relação às outras pessoas e uma atribuição de maior importância às relações significativas, e também a chamada "crise da meia-idade", caracterizada por um período de conscientização sobre a brevidade da vida e de que é inevitável o percurso que um dia há de desembocar na finitude, à medida que essas novas limitações físicas e importantes mudanças nos principais papéis desempenhados até então vão sendo reconhecidas (Kovács, 2010).

Assim, ao considerar a literatura científica devotada à investigação de homens de meia-idade, é possível perceber o quanto a vivência da paternidade nessa fase desafia o que é esperado e entendido como característica desse período do ciclo vital (Colleti \& Scorsolini-Comin, 2015). Tipicamente, os estudos acerca dos homens de meia-idade, com ênfase na parentalidade, identificam essa fase como um momento em que os filhos começam a sair de casa para constituir suas próprias famílias, e que também se dá a entrada de novos membros (noras e/ou genros e netos) no sistema familiar. Assim, focase na necessidade de o casal reestruturar a relação conjugal após a saída dos filhos (Ribeiro, 2005), movimento inverso ao vivenciado pelos homens que se tornaram pais pela primeira vez após os 40 anos. Dessa maneira, pouco se sabe sobre a vivência da paternidade na meia-idade e sobre o modo como pais, mães e filhos a percebem e atribuem sentidos a essa experiência.

Assim, este estudo se justifica, na medida que poderá trazer contribuições à compreensão psicodinâmica da estrutura e dinâmica das familias nas quais a paternidade foi constituída na meia idade, lançando luz aos aspectos familiares internos e externos, subjetivos e objetivos que repercutem na constituição da paternidade e da parentalidade, e nas mudanças que vêm ocorrendo diante das transformações socioculturais da era 
contemporânea. No presente estudo a compreensão sobre a paternidade na meia-idade foi enriquecida pela articulação das diferentes perspectivas, aproximando o olhar do pai, da mãe e dos filhos em relação ao lugar do pai. Nessa vertente, foram indagados: quais seriam as características da experiência da paternidade entre os homens de meia-idade? Haveria conflitos na assunção da paternidade e do papel parental? Que sentidos mães e filhos atribuem à paternidade nessa fase do ciclo vital? A partir desses questionamentos e da constatação de que ainda são poucos os estudos disponíveis acerca da vivência paterna na meia-idade, colocam-se os objetivos deste estudo. 


\section{OBJETIVOS}

O presente estudo teve por objetivo geral compreender a experiência da paternidade na meia-idade, a partir da perspectiva de pais, mães e filhos envolvidos no contexto familiar.

Os objetivos específicos foram:

(1) Conhecer as principais motivações ou explicações formuladas para a paternidade na meia-idade, relatadas pelos pais e suas esposas.

(2) Investigar de que modo as esposas e filhos percebem a experiência paterna na meia-idade.

(3) Examinar possíveis potencialidades e dificuldades do exercício da paternidade nessa fase do ciclo vital, a partir dos relatos dos próprios pais, suas esposas e filhos.

(4) Compreender de que modo a paternidade na meia-idade se relaciona com a experiência da maternidade e com a conjugalidade da díade marital. 


\section{MÉTODO}

\subsection{Tipo de estudo}

Trata-se de um estudo descritivo e exploratório, realizado segundo os fundamentos do estudo de caso. Ou seja, o estudo foi desenvolvido dentro de um enfoque qualitativo de pesquisa, no qual elegeu-se, como estratégia metodológica, a utilização de estudos de casos múltiplos.

De acordo com Denzin e Lincoln (1994), é possível encontrar diversas definições e paradigmas da pesquisa qualitativa, a depender do posicionamento de quem a define. Bogdan e Biklen (1997), definem a metodologia qualitativa como aquela que busca uma melhor compreensão do comportamento e da experiência humana. Nesse sentido, os pesquisadores qualitativos procuram entender o processo pelo qual as pessoas constroem e descrevem significados por meio da observação empírica. Os dados recolhidos são designados por qualitativos, o que significa rico em pormenores descritivos relativamente a pessoas, locais e conversas, e de complexo tratamento estatístico, privilegiando essencialmente, a compreensão dos comportamentos a partir das perspectivas dos sujeitos de investigação.

Tais autores destacam cinco características que consideram estar presentes na investigação qualitativa: (a) Os dados são obtidos no ambiente natural, sendo que o investigador se constitui no principal instrumento do estudo; (b) A investigação qualitativa é descritiva, sendo de suma importância que o pesquisador examine o mundo com a ideia de que nada é trivial e que tudo tem potencial para servir como pistas para investigar o objeto de estudo; (c) Há maior interesse no processo do que apenas nos resultados ou produtos; (d) Os investigadores na pesquisa qualitativa tendem a analisar os seus dados de forma indutiva, ou seja, não recolhem dados com o objetivo de confirmar hipóteses construídas previamente; (e) O interesse está no modo como as pessoas dão sentido às suas vidas, tendo o significado importância vital neste tipo de investigação. Destaca-se que, nem todos os estudos considerados qualitativos possuem as cinco características, no entanto, a questão não se trata se determinada investigação é totalmente qualitativa, mas sim uma questão de grau (Bogdan \& Biklen, 1997),

Denzin e Lincoln (1994) postulam a pesquisa qualitativa como sendo multimetodológica quanto ao foco, envolvendo uma abordagem interpretativa e naturalística, o que significa que os pesquisadores qualitativos estudam os fenômenos no seu setting natural, tentando dar sentido ou interpretar fenômenos em termos dos 
significados que as pessoas lhes trazem. Minayo (1994), por sua vez, descreve a metodologia qualitativa como sendo aquela que busca a incorporação de significados e intencionalidade aos atos, às relações e às estruturas sociais em termos de transformação e construções humanas significativas.

É importante destacar que, mesmo diante das diversas possibilidades de definições de pesquisa qualitativa, é possível, como sistematizado por Turato (2005), encontrar alguns aspectos comuns entre elas, definindo assim um panorama mais geral para o que é a pesquisa qualitativa. Destacadamente, tem-se que os sentidos e os significados dos fenômenos são o cerne para os pesquisadores qualitativos e a busca por capturá-los, ouvindo e observando os sujeitos da pesquisa, bem como fazer interpretações, são os seus objetivos maiores (Turato, 2000). O fato de a pesquisa ser conduzida em ambiente natural desponta como sendo de extrema importância, tendo em vista a noção de impossibilidade de dissociação entre significado e contexto (Turato, 2005).

Assim como com a definição da pesquisa qualitativa, a literatura acerca das origens do estudo de caso, seu significado e caracterização como modalidade de pesquisa conta com contribuições e posições diversas de muitos autores. Becker (1994) e Goldenberg (1997) situam a origem do estudo de caso na pesquisa médica e na pesquisa psicológica, a partir da análise detalhada de um caso individual para explicar a dinâmica e a patologia de uma doença dada, tornando-se assim, posteriormente, uma das principais modalidades de pesquisa qualitativa em ciências humanas e sociais. Para Chizzotti (2006) o estudo de caso como modalidade de pesquisa originou-se nos estudos antropológicos de Malinowski e na Escola de Chicago e, posteriormente, teve seu uso ampliado para o estudo de diversos fenômenos. Gil (1991), por sua vez, relaciona a origem do estudo de caso com o método introduzido por C. C. Laugdell no ensino jurídico nos Estados Unidos, vinculando sua difusão à prática psicoterapêutica caracterizada pela reconstrução da história do indivíduo, bem como ao trabalho dos assistentes sociais junto a indivíduos, grupos e comunidades vulneráveis.

No que tange à caracterização e definição do estudo de caso, pode-se destacar, dentre os diversos autores que se dedicaram à temática, as contribuições de Yin (2001) e Stake (2005). Para Yin (2001), o estudo de caso representa uma investigação empírica e compreende um método abrangente, podendo incluir tanto estudos de caso único quanto de casos múltiplos, assim como abordagens quantitativas e qualitativas de pesquisa. Já em seu entendimento, Stake (2005) caracteriza o estudo de caso pelo interesse em casos individuais e não pelos métodos de investigação que pode abranger. Tal autor chama a 
atenção para o fato de que nem tudo pode ser considerado um caso, pois um caso é uma unidade específica, um sistema delimitado cujas partes são integradas. Ao levar em conta a posição de ambos os autores, Ventura (2007) caracteriza o estudo de caso como modalidade de pesquisa que pode ser entendido como uma metodologia ou como a escolha de um objeto de estudo definido pelo interesse em casos individuais. Destaca que os estudos de caso mais comuns são os que têm o foco em uma unidade - um indivíduo, uma organização - ou múltiplo, nos quais vários estudos são conduzidos simultaneamente (Peres \& Sanches, 2005).

Stake (2005) sistematizou seis preceitos básicos para a produção de um estudo de caso: (a) definir o caso a partir da conceituação do objeto; (b) delimitar a questão a ser investigada; (c) utilizar referencial(is) teórico(s) para compreensão do objeto, entretanto, não se limitando a ele(s); (d) executar a articulação dos métodos, fontes, técnicas de análise e teorias; (e) atentar para as interpretações alternativas para os dados; e (f) elaborar, quando plausível, asserções e generalizações.

De acordo com Yin (2001), o estudo de caso é indicado em três situações específicas: (a) quando os pesquisadores se propõem a testar uma hipótese ou teoria previamente explicitada e amplamente aceita, o chamado estudo de caso crítico; (b) quando os pesquisadores se propõem a estudar um fato que é extremo ou único, o chamado estudo de caso extremo; (c) quando os pesquisadores têm acesso a uma situação ou fenômeno que até então era inacessível à investigação científica, o chamado "caso revelador".

Stake (2005), por sua vez, distingue três tipos de estudos de caso a partir de suas finalidades: (1) Intrínseco ou particular, no qual busca-se melhor compreensão de um caso apenas pelo interesse despertado por aquele caso particular; (2) Instrumental, no qual se tem a crença de que ele poderá facilitar a compreensão de algo mais amplo, podendo servir para fornecer insights sobre um assunto ou para contestar uma generalização amplamente aceita; (3) Coletivo, no qual o pesquisador estuda conjuntamente alguns casos para investigar um dado fenômeno, podendo ser visto como um estudo instrumental estendido a vários casos.

Destaca-se que, ainda que com nomenclaturas distintas, as proposições de ambos os autores, Yin (2001) e Stake (2005) apresentam características que emergem do desejo de investigação de um fenômeno social complexo, pouco investigado, e diz respeito às características significativas e holísticas de eventos da vida real (Alves-Mazzotti, 2006). 
No que tange ao objetivo e período de seguimento do presente estudo, trata-se de um estudo descritivo, exploratório e transversal, que teve como objetivo, de modo geral, a descrição e compreensão da experiência da paternidade na meia-idade, em que buscou-se identificar e analisar conceitos e ideias presentes nos discursos das participantes, procurando esclarecer os sentidos e significados envolvidos (Gil, 1991), a partir de um momento específico das suas trajetórias de vida, ainda que esse momento esteja inserido em um contexto mais amplo (Polit, Becker, \& Hungler, 2004).

\subsection{Participantes}

Os participantes deste estudo foram escolhidos por critérios de conveniência, sendo contatados a partir das redes pessoais de contato da pesquisadora. Assim, a partir de critérios de inclusão preestabelecidos, foram convidados a participar do estudo casais heterossexuais e seus filhos biológicos, inseridos em um contexto familiar em que: (a) o homem tenha se tornado pai pela primeira vez durante a faixa etária dos 40 aos 60 anos de idade; (b) filho com idade igual ou superior a cinco anos; (c) houvesse coabitação do casal e de seu filho, independentemente do tipo de relação estabelecida entre o casal (casados, recasados, união estável). Não houve restrições em relação ao sexo do filho e à idade da mãe ou idade em que ela se tornou mãe, uma vez que o foco não foi a maternidade, mas sim a compreensão, por parte das mães, acerca da paternidade. Também não houve restrições em termos de grau de escolaridade dos participantes, cidade que residiam e classificação econômica da família.

Ressalta-se que não há consenso na literatura científica em relação à definição da faixa etária que corresponderia à meia-idade (Ferreira, 2008). A classificação etária proposta pela Organização Mundial de Saúde (OMS, 2005) considera pessoas com 45 a 59 anos. Alguns autores consideram que abrange a fase que vai dos 40 aos 60 anos de idade (Leão \& Gíglio, 2002). Outros argumentam que o aumento da expectativa de vida e a redução do número de filhos por familia fizeram essa fase se tornar a mais longa do ciclo de vida familiar, costumando decorrer entre os 45 e os 65 anos (Ribeiro, 2005). Há, ainda, quem a defina apenas como a faixa etária dos 50 anos (Ferreira, 2008). Desta forma, no presente estudo delimitou-se a faixa etária dos 40 aos 60 anos.

Quanto aos critérios de exclusão dos participantes, não puderam participar do estudo famílias que: (a) o casal estivesse em processo de separação conjugal; (b) um dos membros possuísse alguma deficiência que o incapacitasse de participar da pesquisa. 
Foram recrutados um total de seis núcleos familiares, sendo que, destes, três haviam participado anteriormente da minha pesquisa de iniciação científica e três foram encontrados a partir da minha rede pessoal de contatos. Dos seis núcleos familiares, um recusou o convite, devido a doença de um membro da familia paterna, enquanto do outro núcleo familiar, recebeu-se a informação, por parte da esposa, que o casal estava vivendo um momento de crise no relacionamento e, portanto, optaram por não participar.

Destaca-se que, para além dos contatos já obtidos devido à minha pesquisa de iniciação científica, a busca por possíveis núcleos familiares que se enquadravam nos critérios de inclusão da pesquisa, se deu também a partir da utilização da minha rede pessoal de contatos inserida em escolas, como por exemplo, pedagogas, que colocaram bilhetes nos cadernos de alunos explicando acerca da pesquisa. A este respeito, destaca-se que, além dos seis núcleos familiares que se enquadravam inicialmente aos critérios de inclusão, um total de mais quatro pais manifestaram interesse em participar da pesquisa. No entanto, os filhos destes possuíam idade menor de cinco anos, o que impossibilitaria meu acesso a estes, uma vez que meu objetivo envolvia a perspectiva de pais, mães e filhos.

A seguir, apresenta-se uma tabela contendo os dados de identificação das quatro famílias participantes do presente estudo. Destaca-se que uma apresentação detalhada de cada núcleo familiar será apresentada posteriormente, na sessão de Resultados, iniciando cada estudo de caso.

Tabela 1: Caracterização das famílias com relação aos cônjuges, filhos e suas idades

Família Cônjuges (idade em anos) Filhos (idade em anos)

\begin{tabular}{lll}
\hline Campos & Pedro (47) e Alice (39) & Isabela (6) \\
\hline Sampaio & Joel (61) e Estela (32) & André (12), Augusto (9) e Ângelo (4) \\
\hline Azevedo & Paulo (53) e Pâmela (46) & Vitória (12) \\
\hline Pires & Antônio (61) Cristina (55) & Ana Júlia (16) \\
\hline
\end{tabular}

Destaca-se que os nomes de todos os participantes são fictícios para evitar a identificação e assegurar o direito ao sigilo e à confidencialidade das informações fornecidas pelos participantes. Os sobrenomes que designam cada família foram 
escolhidos pela própria pesquisadora, enquanto que os nomes fictícios de cada membro destas foram escolhidos pelos próprios participantes, a pedido da pesquisadora.

\subsection{Instrumentos}

Os instrumentos utilizados para a coleta de dados foram:

\section{3.1. Formulário de Dados Sociodemográficos}

Trata-se de um formulário utilizado pelo Laboratório de Ensino e Pesquisa em Psicologia da Saúde - LEPPS-USP-CNPq (Apêndice A), que envolve dados pessoais, sociais e econômicos dos participantes, englobando ainda o Critério de Classificação Econômica Brasil (Associação Brasileira de Empresas de Pesquisa [ABEP], 2015).

O Critério de Classificação Econômica Brasil (CCEB) foi criado em 1997, a partir da junção de dois outros critérios: ABA-ANEP e Critério ABIPEME, passando por diversas revisões. O formato do instrumento utilizado no presente estudo é fruto de sua última revisão, realizada em 2015. Enfatiza-se que desde 2008 o CCEB deixou de realizar a classificação da população em termos de "classes sociais" e passou a separar o mercado a partir de classes econômicas, em função da estimativa do poder de compra das pessoas e das famílias urbanas, conforme a renda familiar auferida (ABEP, 2015).

O CCEB/2015 é composto pela avaliação de vários itens indicadores discriminantes de renda, dentro os quais estão: automóveis, motocicletas, empregados mensalistas, máquinas de lavar roupa, banheiros, DVDs, geladeiras, freezers, microcomputadores, lavadora de louça, microondas e nível educacional do chefe da família. A posse de tais itens é pontuada e, assim, de acordo com a pontuação de corte das classes estabelecidas pelo instrumento, o indivíduo é classificado, respectivamente, nos estratos correspondentes aos pontos obtidos (ABEP, 2015).

\subsubsection{Roteiros de entrevista}

A entrevista é considerada uma das estratégias mais representativas da investigação qualitativa e que melhor ilustra suas características, sendo utilizada em diálogos que almejam que os participantes descrevam e interpretem, em linguagem própria, os aspectos do mundo (Bogdan \& Biklen, 1997). É considerada uma modalidade de interação dirigida entre duas ou mais pessoas, tendo como objetivo a troca de 
informações e redução de incertezas acerca do que o interlocutor diz. Deste modo, pode ser considerada uma forma de interação social que valoriza o uso da palavra, símbolo e signo privilegiados das relações humanas, por meio da qual os atores sociais constroem e procuram dar sentido à realidade que os cerca (Flick, 2002; Jovechlovitch \& Bauer, 2002).

Dentre as vantagens do uso da entrevista como técnica de pesquisa na perspectiva qualitativa, Fraser e Gondim (2004) destacam o fato deste recurso favorecer a relação intersubjetiva do entrevistador com o entrevistado, e, por meio das trocas verbais e não verbais, permitir uma melhor compreensão dos significados, dos valores e das opiniões dos atores sociais a respeito de situações e vivências pessoais. Chamam atenção ainda para a flexibilização na condução do processo de pesquisa e na avaliação de seus resultados, visto que o entrevistado tem um papel ativo na construção da interpretação do pesquisador, favorecendo o acesso direto ou indireto às opiniões, às crenças, aos valores e aos significados que as pessoas atribuem a si, aos outros e ao mundo circundante. Deste modo, a entrevista dá voz ao interlocutor para que ele fale do que está acessível a sua mente no momento da interação com o entrevistador e em um processo de influência mútua, entre pesquisador e participante, produz um discurso compartilhado pelos dois atores (Fraser \& Gondim, 2004).

Em relação à sua estruturação, as entrevistas podem ser definidas como estruturadas, semiestruturadas ou não estruturadas. As entrevistas estruturadas ou fechadas são utilizadas, frequentemente, em pesquisas quantitativas e experimentais. A preocupação é com o ajuste do roteiro às hipóteses previamente definidas, a padronização da apresentação de perguntas e a limitação das opções de respostas para facilitar o planejamento das condições experimentais e do tratamento estatístico dos dados (Fontana \& Frey, 2000). As entrevistas mais comumente utilizadas nas pesquisas qualitativas são as semiestruturadas e as não-estruturadas. A opção por uma delas está relacionada com o nível de diretividade que o pesquisador pretende seguir, variando desde a entrevista na qual o entrevistador introduz o tema da pesquisa e deixa o entrevistado livre para discorrer sobre o mesmo, fazendo apenas interferências pontuais, até a entrevista um pouco mais estruturada, que segue um roteiro de tópicos ou perguntas gerais (Bartholomew, Henderson, \& Márcia, 2000). Assim, a partir da literatura e tendo em vista os objetivos do presente estudo foram elaborados e utilizados três roteiros de entrevista semiestruturados: 
Roteiro de entrevista semiestruturado com o pai (Apêndice B): O roteiro foi aplicado individualmente com o pai, em que, em linhas gerais, foram coletados dados referentes à sua idade; escolaridade; renda familiar; emprego/ocupação; religião; experiência da paternidade na meia-idade; vivência da conjugalidade antes e depois da transição para a parentalidade, relação com o(a) filho(a); dificuldades e possibilidades no processo de construção da paternidade na meia-idade e demais questões que atendiam aos objetivos propostos.

Roteiro de entrevista semiestruturado com a mãe (Apêndice C): $\mathrm{O}$ roteiro foi aplicado individualmente com a mãe. Foram coletados dados referentes à idade, escolaridade, renda familiar, emprego/ocupação, religião, percepções acerca da experiência da paternidade na meia-idade, experiência da conjugalidade antes e depois da parentalidade, percepções acerca de possíveis dificuldades e/ou possibilidades no processo de construção da paternidade nessa fase do ciclo vital e demais questões que atendiam aos objetivos do presente estudo.

Roteiro de entrevista semiestruturado com o(a) filho(a) (Apêndice D): Foi aplicado individualmente com o(a) filho(a) com idade igual ou superior a 12 anos. Em linhas gerais, foram coletados dados referentes ao dia a dia, rotina familiar, atividades realizadas com cada membro do casal, percepções e singularidades acerca de sua relação com seu pai e demais questões que atendiam aos objetivos do presente estudo.

\subsubsection{Desenho da Família (DF)}

O Desenho da Família (DF), consiste em uma técnica empregada na avaliação de personalidade de crianças em contexto clínico desde 1931 por N. Appel (Ortega, 1981). Considerado um bom instrumento para a avaliação de conflitos familiares vividos por crianças, durante o desenvolvimento do instrumento, diversas foram as formas descritas de instrução e interpretação dos materiais (Wagner \& Bandeira, 1996).

Apesar de seu uso anterior, foi Porot (1952) quem codificou a situação de exame do Desenho da Família, propondo uma técnica que consiste em solicitar à criança: "Desenhe sua familia", caracterizando desta maneira a familia verdadeira e destacando a importância de anotar a ordem de aparecimento dos personagens, os eventuais retornos, as rasuras, as hesitações. Tal autor propõe analisar o seu conteúdo do desenho a partir da 
ênfase em três aspectos: (a) a composição da familia; (b) as valorizações e desvalorizações dos diferentes elementos constituintes; (c) a situação na qual o sujeito se coloca em relação aos seus (Ortega, 1981).

Posteriormente, Corman (1970) elaborou um novo método para aplicação e interpretação do DF, no qual sua proposta consiste na seguinte instrução: "Desenhe uma família, uma família que você imagina", a fim de possibilitar mais liberdade na projeção das tendências inconscientes, sendo sua análise compreendida a partir de três níveis: (a) gráfico, (b) das estruturas formais, e (c) de conteúdo (Ortega, 1981).

Dentre as contribuições sobre a validação do Desenho da Família, Ortega (1981) destaca as de Morval. Para Morval, a instrução de Corman (1970), possibilita um maior grau de liberdade de projeção das tendências inconscientes, no entanto, tal autora ressalta que é necessário adaptar a instrução, tendo em vista o problema que se deseja estudar. Dessa maneira, "Desenhe sua família" seria mais conveniente para analisar as atitudes em relação à mãe e à fratria, ao passo que "Desenhe uma familia que você imagina" seria aconselhável para estudar as atitudes em relação ao pai (Ortega, 1981).

No presente estudo, o DF foi aplicado individualmente com os filhos menores de 12 anos, em que, almejou-se investigar a percepção que o(a) filho(a) tem de seus pais e de sua relação com eles, com foco principalmente na figura paterna e na percepção do modo como o pai exerce a paternidade. A técnica projetiva foi aplicada mediante a consigna: "Desenhe uma família".

\subsubsection{Genograma}

O Genograma Familiar é uma representação gráfica que mostra o desenho ou mapa da família, sendo amplamente utilizado na Terapia Familiar, na atenção primária à saúde e, recentemente, como um instrumento científico para coleta de dados, especificamente em pesquisas qualitativas com familias. Desse modo, o Genograma pode ser considerado como um instrumento que auxilia a familia a expressar-se, e que vem somar-se à gama de instrumentos de coleta de dados (Wendt \& Crepaldi, 2008).

De modo geral, tal instrumento representa o mapeamento gráfico da história e do padrão familiar, mostrando a estrutura básica, a demografia, o funcionamento e os relacionamentos da família, configurando-se como um gráfico sumário dos dados coletados (McGoldrick \& Gerson, 1995) e, explicitando a estrutura familiar ao longo de várias gerações e das etapas do ciclo de vida familiar (Wendt \& Crepaldi, 2008). No que 
tange a suposição teórica, este baseia-se na compreensão de que o funcionamento dos membros familiares em diferentes níveis é interdependente, e quando uma parte do sistema familiar muda, todo o resto é afetado (Marchetti-Mercer \& Cleaver, 2000).

Considerando ainda que, certos padrões familiares são recorrentes, o uso do Genograma possibilita fazer determinadas predições sobre os processos futuros que a familia vivenciará (Carter \& McGoldrick, 1995) e, também, acessar os principais mitos e crenças que norteiam a vida da familia e que tendem a ser transmitidos ao longo das gerações. De acordo com Wendt \& Crepaldi (2008), a partir de extensa consulta à literatura sobre o tema, existem dez padrões de relacionamento que podem ser expostos nos genogramas, sendo estes:

O relacionamento harmônico: é aquele no qual existe a experiência emocional de união entre dois ou mais membros familiares que nutrem sentimentos positivos um para com o outro. Nesse tipo de relacionamento existe a clara diferenciação dos membros entre si e com suas respectivas famílias de origem.

$\mathrm{O}$ relacionamento muito estreito ou superenvolvimento: diz respeito àqueles relacionamentos nos quais existe fusão e dependência emocional entre os membros familiares, ou seja, são aqueles relacionamentos nos quais não existe diferenciação entre seus membros.

O relacionamento fundido e conflitual: se caracteriza pela estreita dependência emocional e pela presença constante de conflitos entre os membros familiares, não havendo diferenciação entre os mesmos.

Aliança: relacionamento no qual existe uma ligação baseada nas lealdades invisíveis que interferem, também, no processo de diferenciação, porém em menor grau que o superenvolvimento.

O relacionamento conflituoso: caracteriza-se pelas relações nas quais há constantes atritos que podem gerar ansiedade e desavenças no meio familiar, dando origem a dificuldades de comunicação como desqualificações e desconfirmações do outro, podendo, em níveis extremos, atingir um nível de violência física.

O relacionamento vulnerável: diz respeito aos relacionamentos nos quais não há conflito explícito, mas que, apresentam risco de haver conflitos em condições adversas ou fases de transição.

O relacionamento distante: observado geralmente nas familias desligadas, com fronteiras rígidas, em que o relacionamento entre os membros caracteriza-se por pouco ou nenhum contato, sobretudo no que diz respeito a aspectos emocionais. 
O rompimento: característico dos relacionamentos nos quais a ligação emocional entre os membros é mantida, ainda que não exista contato entre os membros.

A triangulação: configuração emocional de três pessoas, na qual existe uma pessoa dita "triangulada" que cumpre uma função periférica de regulação da tensão existente entre as outras duas.

A coalizão: aliança entre duas pessoas em detrimento de uma terceira.

As legendas do Genograma, desenvolvidas por Wendt e Crepaldi (2008) e utilizadas na elaboração do instrumento no presente estudo encontram-se no Anexo 1.

\subsubsection{Diário de campo}

A utilização de notas de campo oferece um suplemento importante aos outros instrumentos utilizados, permitindo que o pesquisador obtenha informações valiosas e detalhadas dos fatos ocorridos no campo de coleta de dados, incorporando os aspectos não verbais e também as suas impressões, sentimentos e percepções que configuram a contratransferência da pesquisadora (Bogdan \& Biklen, 1997).

De acordo com Bogdan e Biklen (1997) o diário de campo é composto por dois tipos de materiais: a parte descritiva e a parte reflexiva, na qual a primeira representa $o$ registro do investigador acerca dos detalhes do que ocorreu no campo, englobando assim, os retratos dos sujeitos; reconstruções do diálogo; descrição do espaço físico; relatos de acontecimentos particulares; descrição de atividades e comportamento do observador, enquanto que, a segunda refere-se a parte mais subjetiva do investigador, em que a ênfase está na especulação, sentimentos, problemas, ideias, palpites, impressões e preconceitos. Tais autores aconselham ainda que, de tempos em tempos, o investigador escreva fragmentos de pensamentos adicionais acerca do progresso da investigação, o que é denominado de memorandos, que contêm reflexões do investigador a respeito da análise, do método, de seus conflitos, de seu ponto de vista e os pontos de codificação.

Assim, a fim de complementar os dados da pesquisa, foram tomadas notas de campo após a aplicação dos instrumentos da pesquisa, nas quais, assim como a orientação de Bogdan e Biklen (1997), buscou-se escrever da maneira a mais detalhada possível aquilo que foi visto, ouvido, vivenciado e pensado no decurso da coleta de dados.

\section{4. Procedimento}

A coleta e análise dos dados, seguiram as seguintes etapas: 


\subsubsection{Seleção dos participantes}

Os participantes da pesquisa foram recrutados a partir da rede pessoal de contatos da pesquisadora, com base nos critérios de inclusão e exclusão estabelecidos previamente. Assim, como dito anteriormente, a participação de duas famílias- Família Sampaio e Familia Pires- se deu a partir de contato já realizado anteriormente em minha pesquisa de iniciação científica, enquanto que, a participação da Família Campos e da Família Azevedo se deu por intermédio de membros da rede pessoal de contatos da pesquisadora.

\subsubsection{Aplicação dos instrumentos}

A coleta de dados ocorreu a partir de contato prévio por telefone com ao menos um membro de cada familia. Assim, de acordo com a disponibilidade de todos os membros das familias, estabeleceu-se a data e horário e local dos encontros que tiveram uma duração variável, entre duas e seis horas. Destaca-se que, devido à dificuldade de conciliar uma data e horário em que todos os membros da familia estivessem presentes, a Familia Azevedo sugeriu que a coleta fosse realizada via Skype e assim foi realizado, enquanto que, em relação as demais famílias, a coleta foi realizada em situação face a face na casa dos participantes. Desta forma, a pesquisadora deslocou-se para três cidades diferentes do interior de São Paulo.

Os instrumentos foram aplicados com os membros das famílias em cômodos reservados da casa pelos próprios participantes. A ordem de aplicação dos instrumentos foram: Formulário da Dados Sociodemográficos e Critério de Classificação Econômica Brasil e roteiro de entrevista semiestruturado. A aplicação dos roteiros de entrevista foi realizada individualmente com cada membro da família, no entanto, a ordem dos familiares entrevistados variou de acordo com a preferência de cada família no momento do encontro com a pesquisadora.

O Genograma Familiar foi construído ao final do encontro com cada família, em que houve a participação de todos os membros. A aplicação de todos os instrumentos foi audiogravada na íntegra por meio de um gravador MP3, mediante anuência das participantes, assegurando maior fidedignidade dos dados colhidos e objetividade do estudo. Nas gravações ficaram registradas a linguagem falada, com a entonação e intensidade das verbalizações, o que auxiliou a análise dos dados. 
Destaca-se que, no caso da Família Azevedo, os termos de consentimento foram enviados pela pesquisadora por e-mail à familia que, por sua vez, os imprimiu e os assinou, enviando à pesquisadora por correio.

É importante ressaltar que antes de iniciar a coleta de dados foi explicado a cada membro da família, de forma detalhada, a natureza e os objetivos do estudo, solicitando assim que eles assinassem o Termo de Consentimento Livre e Esclarecido - TCLE (Apêndices E, F e G) para participação na pesquisa, em que constavam por escrito os objetivos, o método, a responsabilidade ética da pesquisadora com os dados obtidos e a possibilidade de desistência da entrevistada a qualquer momento do processo de coleta de dados.

\subsubsection{Análise dos dados}

Após a aplicação dos instrumentos de coleta de dados foi iniciada a organização e análise dos dados recolhidos. Os materiais foram organizados a partir dos procedimentos de análise temática preconizados por Braun e Clarke (2006), seguindo-se, desta forma, os seguintes passos metodológicos:

(1) Familiarizando-se com os dados: Transcrição dos dados, seguida pela leitura e releitura destes, anotando ideias iniciais.

(2) Geração de códigos iniciais: Codificação das características interessantes dos dados de forma sistemática em todo o conjunto de dados, reunindo assim dados relevantes para cada código.

(3) Procurando por temas: Reunião dos códigos em temas potenciais, recolhendo todos os dados relevantes a cada tema potencial.

(4) Revisando temas: Checagem do funcionamento dos temas em relação aos extratos codificados (nível 1) e a todo o conjunto de dados (nível 2), gerando um "mapa" temático da análise.

(5) Definindo e nomeando temas: Análise contínua para refinar as especificidades de cada tema e a história geral que a análise conta; geração de definições claras e nomes para cada tema.

(6) Produzindo o relatório: Seleção de exemplos de extratos evocativos e convincentes, análise final dos extratos selecionados, retornando da análise de volta à questão de pesquisa e literatura, produzindo um relatório acadêmico da análise. 
Ressalta-se que tais fases foram utilizadas como guias para auxiliar na organização dos dados e não regras, uma vez que, segundo Braun e Clarke (2006), estas deverão ser aplicadas de maneira flexível para compreensão das questões de investigação e dos dados, visto que, a análise dos dados não é um processo linear, mas sim um processo recursivo, em que o pesquisador se move para trás e para a frente, conforme necessário, ao longo do fases (Braun \& Clarke, 2006).

A interpretação dos materiais obtidos foi pautada no referencial psicanalítico francês da transmissão psíquica entre as gerações e pela literatura disponível sobre o tema da paternidade. Faz-se importante a consideração de que as construções temáticas apresentadas nos resultados não esgotam, em absoluto, as possibilidades de olhar para os dados, uma vez que, concebe-se os temas aqui trabalhados como uma construção singular da pesquisadora em questão.

\subsection{Cuidados Éticos}

Em relação às exigências éticas, o projeto do presente estudo foi enviado ao Comitê de Ética em Pesquisa da Faculdade de Filosofia, Ciências e Letras de Ribeirão Preto da Universidade de São Paulo (CEP-FFCLRP-USP), obtendo aprovação sob o processo CAAE $\mathrm{n}^{\circ}$ 43882215.4.0000.5407 (Anexo 2). A execução do projeto foi amparada na resolução no 466/2012 do Conselho Nacional de Saúde, que regulamenta a pesquisa envolvendo seres humanos Brasil, 2012).

A participação das famílias no estudo foi voluntária, de modo que, antes do início da coleta dos dados, como já mencionado anteriormente, todos os sujeitos formalizam sua anuência mediante a assinatura do termo do TCLE (Apêndices E e F). Para os participantes menores de 18 anos foi solicitada aos pais ou responsáveis a autorização de sua participação por meio de sua anuência expressa na assinatura de um TCLE específico para tais situações (Apêndice G).

Em relação ao material audiogravado, os registros serão armazenados por um período de cinco anos após a conclusão do presente estudo no LEPPS, laboratório do grupo de pesquisa, como forma de resguardar a privacidade do material e manter a identidade dos participantes em sigilo, em atenção às disposições éticas vigentes. 


\section{RESULTADOS E DISCUSSÃO}

Os resultados do presente estudo estão apresentados em duas partes: primeiramente será realizada a caracterização de cada família participante, em termos de integrantes, tipo de união, profissão/ocupação, idade, religião e classificação socioeconômica. Ainda nesta primeira parte será apresentado o genograma de cada família, juntamente com alguns dados de cada integrante e uma contextualização do encontro da pesquisadora com os mesmos, compondo assim um eixo descritivo. Posteriormente, serão apresentadas as análises conjuntas das quatro famílias participantes, de forma a expor as categorias temáticas destacadas a partir dos discursos de seus integrantes, contemplando, desse modo, a opção metodológica de estudos de casos múltiplos elegida para a construção desta investigação.

\subsection{Eixo Descritivo}

\section{1.1 Estudo de Caso 1: Família Campos}

Quem são os integrantes da família Campos? Uma breve apresentação e contextualização

\section{Tabela 2}

Caracterização da família Campos em termos de integrantes, estado civil, escolaridade ocupação/profissão, idade, religião e classificação socioeconômica.

\begin{tabular}{|c|c|c|c|c|c|c|c|c|}
\hline Família & \multicolumn{2}{|c|}{ Integrantes } & $\begin{array}{l}\text { Tipo de } \\
\text { União }\end{array}$ & Escolaridade & $\begin{array}{l}\text { Profissão/ } \\
\text { Ocupação }\end{array}$ & $\begin{array}{l}\text { Idade } \\
\text { (anos) }\end{array}$ & Religião & $\begin{array}{c}\text { Classificação } \\
\text { Socioeconômica }\end{array}$ \\
\hline \multirow{3}{*}{ Campos } & \multirow{2}{*}{ Pais } & Pedro & \multirow[b]{2}{*}{$\begin{array}{l}\text { Casados } \\
(8 \text { anos })\end{array}$} & $\begin{array}{c}\text { Ensino } \\
\text { Superior } \\
\text { Incompleto } \\
\end{array}$ & Comerciante & 47 & Católica & \multirow{3}{*}{$\begin{array}{c}\mathrm{A} \\
(\mathrm{R} \$ 15.000)\end{array}$} \\
\hline & & $\begin{array}{c}\text { E } \\
\text { Alice }\end{array}$ & & $\begin{array}{c}\text { E } \\
\text { Ensino } \\
\text { Superior } \\
\text { Completo com } \\
\text { pós-graduação }\end{array}$ & $\begin{array}{c}\text { E } \\
\text { Dentista }\end{array}$ & 39 & Católica & \\
\hline & Filha & Is abela & - & $\begin{array}{l}\text { Pré-escola } \\
\text { (cursando) }\end{array}$ & Estudante & 6 & Católica & \\
\hline
\end{tabular}


A Familia Campos é constituída por Pedro (pai), Alice (mãe) e Isabela (filha do casal). Pedro, 47 anos, optou por não concluir dois cursos de graduação para investir em um comércio em sociedade com seu irmão. Alice, 39 anos, cursou graduação e pósgraduação em odontologia e atua em seu consultório odontológico. Isabela, filha do casal, 6 anos, é estudante da pré-escola em uma instituição particular.

Pedro e Alice se conheceram há pouco mais de 11 anos e estão casados há oito anos. A Familia Campos reside em casa própria, na cidade natal de Pedro, onde este possui seu comércio e, Alice, por sua vez, comprou seu consultório odontológico. Em relação a religião, a familia se autodenomina católica, mas destaca que há algum tempo não são praticantes da religião.

Como também é possível observar, a familia pertence ao nível socioeconômico $\mathrm{A}$, de acordo com o Critério de Classificação Econômica Brasil, o que os coloca entre os 2,9\% da população brasileira pertencente a esse nível econômico, o mais alto da escala desenvolvida pela ABEP (2015). Destaca-se que a renda mensal familiar é de 15 mil reais mensais, sendo que destes, 9 mil referem-se a renda de Pedro em seu comércio e 6 mil referem-se a renda de Alice em seu consultório odontológico.

A seguir será apresentado o Genograma da Família Campos:

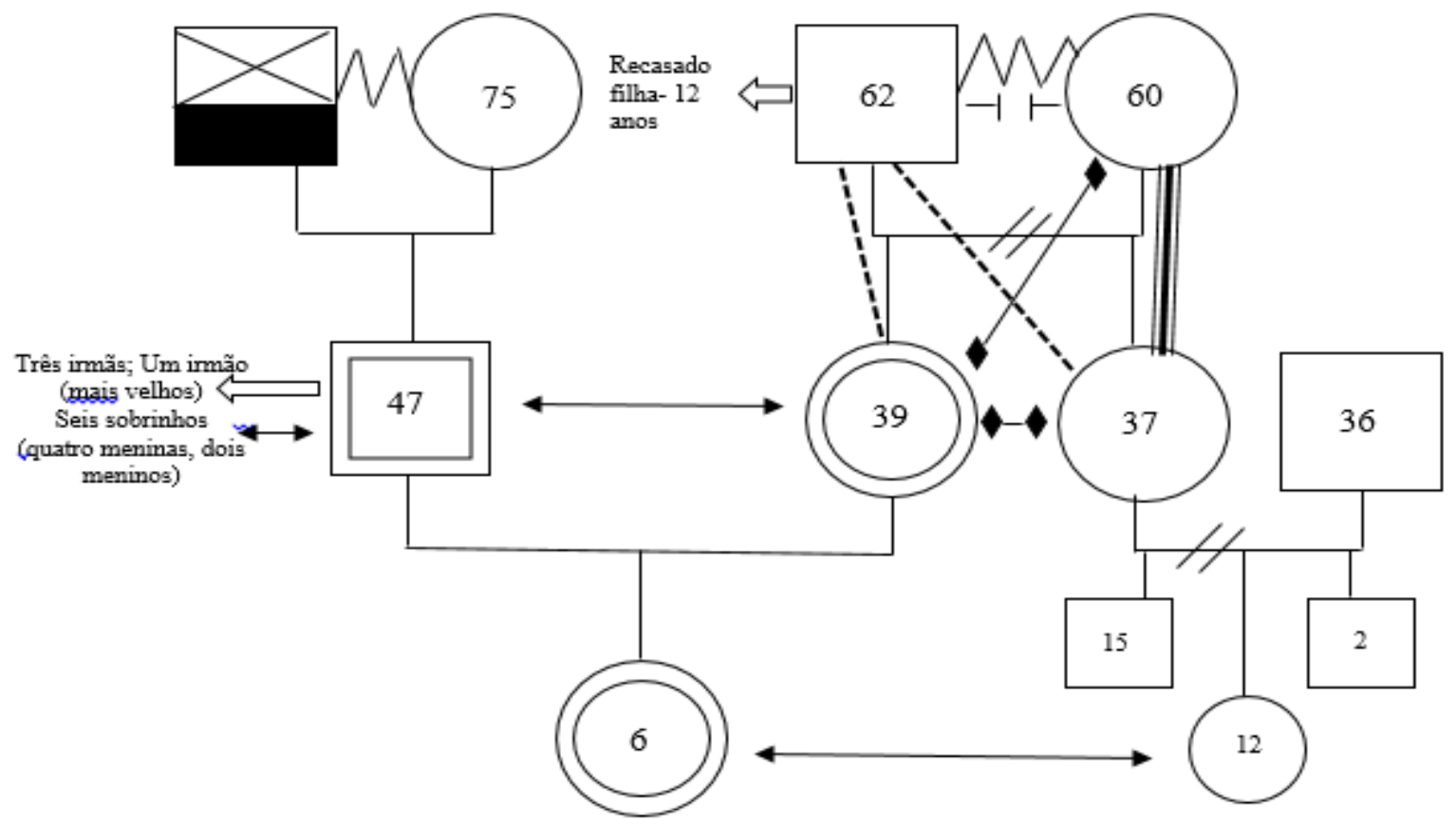

Figura 1. Genograma da Familia Campos 
Destaca-se que, após o contato aprofundado com todos os dados provenientes da coleta de dados, durante a análise verificou-se a dificuldade da pesquisadora de distinguir os dados provenientes exclusivamente da construção do genograma daqueles provenientes das entrevistas individuais. Deste modo, optou-se por apresentar a dinâmica das relações familiares a partir do detalhamento da trajetória pessoal de cada membro da família e da contextualização do encontro destes membros com a pesquisadora, o que será apresentado abaixo:

\section{$\underline{\text { Pedro }}$}

Pedro, branco, 47 anos, comerciante, natural e residente de um pequeno município do interior do estado de São Paulo, é o filho caçula de uma família constituída por pai (falecido), mãe e cinco filhos, sendo três mulheres e dois homens, seguindo esta ordem de nascimento. Em seu discurso, Pedro relata que possui um bom relacionamento com todos os membros de sua família, ainda que destaque a compreensão de que certo afastamento é natural, uma vez que, cada um de seus irmãos possui suas próprias famílias e estão envolvidos nos cuidados destas:

Eu me dou bem com todos eles, a gente se dá bem sabe [pausa] admiro muito a familia que eles construíram e as coisas que eles fazem pelos filhos, pego como exemplo. A gente tenta sempre tá junto, mas acho que é natural cada um cuida mais da sua família né, correria do dia-dia, é normal (Pedro, 47 anos).

Em relação aos seus pais, o participante relatou um vínculo muito forte com sua mãe e com seu pai (falecido). Atribuiu esta proximidade ao fato de ser o filho caçula e ter residido com ambos até os 38 anos. Percebeu-se que o vínculo com sua mãe está relacionado a noção de cuidado, o que envolve tanto o cuidado recebido ao longo de seu desenvolvimento quanto o cuidado que hoje Pedro dedica a ela, devido a sua idade, 75 anos, a viuvez e ao fato dele se considerar o filho mais próximo, fisicamente e afetivamente:

Eu fiquei mais tempo dentro da casa dos meus pais e talvez por isso que eu tenha casado mais tarde. Eu fiquei até 38 anos. Minha mãe é alguém que estava sempre ali, cuidando da gente [pausa]. Ela quem criou a gente né. Hoje consigo retribuir 
estas coisas sabe, ela já está velhinha, depois que meu pai faleceu eu acho que fiquei ainda mais próximo dela, cuido dela e procuro retribuir todo cuidado que ela teve comigo e com meus irmãos né (Pedro, 47 anos).

Pedro expressou um vínculo afetivo muito forte com seu Pai, relembrando momentos vivenciados com este e valorizando aspectos positivos deste na função de pai, ainda que em seu discurso ressalte a ausência do pai no cuidado dos filhos e também os transtornos causados na família devido a sua dependência química, em especial, na relação com sua mãe:

Meu pai praticamente não viu a gente crescer, então ele tinha aquele jeitão [pausa] a gente percebia o carinho dele, mas era seco né, trabalhava muito, era um construtor sabe, mas ele tinha os dois lados, tinha o jeito dele de ser carinhoso... Quando eu fiquei mais velho e fui construindo minhas coisas eu fazia questão dele participar de tudo, na hora que ia comprar carro, de tudo. Não posso te mentir, ele bebia muito, isso machucava muito minha mãe e a gente, mas apesar de tudo eu acho que ele foi um bom pai, ensinou muita coisa boa pra gente... era o jeito dele (Pedro, 47 anos).

Quanto a sua formação profissional, logo quando se formou no ensino médio Pedro iniciou a faculdade cursando Engenharia e depois Processamento de Dados. Acreditando incialmente que não havia se identificado com o primeiro curso, optou pela troca, no entanto, foi então que percebeu que, na verdade, não se identificava com uma rotina de estudos e apresentava um desejo de trabalhar e ganhar seu próprio dinheiro, o que se concretizou ao abrir, em sociedade com seu irmão, um bar, no qual trabalha até os dias de hoje:

$\mathrm{Na}$ verdade eu entrei em engenharia e depois troquei de faculdade, pra processamento de dados, só que eu não me encontrei nessa rotina de estudos, me encontrei foi no comércio mesmo sabe. Até quando eu fui largar da faculdade foi um problema com mãe, com irmãos e tal, que eles não queriam que eu largasse, mas eu me encontrei no comércio e sou muito feliz hoje (Pedro, 47 anos). 
No que diz respeito aos seus planos de casar-se e ter filhos, Pedro relatou que antes de conhecer Alice havia tidos alguns relacionamentos amorosos, no entanto, não pensava em casar e nem desejava ter filhos. Em seu discurso Pedro retomou o momento em que conheceu Alice, a decisão de casar-se, e o modo como o desejo dela em ter filhos proporcionou uma desconstrução de seu desejo de não os ter:

Então, eu tenho um bar aqui na frente, meu comércio é aqui na frente. Ela trabalhava em outra cidade, nisso ela veio e comprou esse consultório e logo que ela chegou eu já tive esse contato com ela. Fizemos amizade e a gente foi se conhecendo e então depois de três anos de namoro a gente foi morar junto um pouquinho. Engraçado é que eu não queria ter filho né e ela sonhava em ser mãe desde o começo. A gente sabia os desejos uns dos outros, mas a gente foi conversando e ela queria muito [pausa] sempre deixou claro pra mim que queria. Foi assim, uma negociação, acho que eu não queria porque tinha medo do mundo, mas conversamos e quando tomamos uma decisão decidimos nos casar no papel tudo certinho (Pedro, 47 anos).

Em relação a paternidade, Pedro definiu sua relação com Isabela como harmoniosa, no entanto, relatou o desejo de interagir mais com sua filha, no sentido de brincadeiras e conversas, se avaliando enquanto pai e refletindo sobre os motivos que estariam envolvidos no modo como ele tem exercicido a função paterna:

Então, a maioria das vezes eu chamo atenção. Aí é falta de paciência da minha parte. Ela tem atitudes de uma criança normal, esperta, inteligente, quer brincar, se divertir, que aproveitar o pai a mãe. Eu queria muito brincar e conversar mais. Eu sempre fui impaciente, ansioso, mas acho que as vezes é disposição sabe, não só por conta do trabalho, mas pela idade, de achar difícil entrar no mundo dela. Acho que é um processo né, eu me cobro e tento mudar a cada dia (Pedro, 47 anos).

\section{Alice}

Alice, branca, 39 anos, dentista, natural de uma cidade localizada interior do estado de São Paulo, é a filha mais velha de uma familia constituída por, segundo ela, dois núcleos familiares: sua mãe e sua irmã (37 anos); seu pai, sua madrasta e sua irmã 
mais nova (12 anos). Em seus relatos, a participante discorreu sobre o relacionamento conflituoso de seus pais, que culminou na separação do casal há, aproximadamente, 15 anos, sendo seguido pela união de seu pai com uma nova companheira com quem hoje ele tem uma filha de 12 anos.

Alice nomeou a relação com sua mãe e com sua irmã como vulnerável, no sentido de que considera que ambas são pessoas difíceis de lidar, o que não significa que não mantenham um relacionamento próximo. Alice avalia sua mãe como a responsável pelos cuidados dela e de sua irmã, e seu pai como alguém distante, o que envolve tanto o tempo em que viviam juntos quanto agora que seus pais estão separados:

Meus pais já não viviam bem a muito tempo. Eles não viviam bem, minha mãe é uma pessoa difícil, mas o que as pessoas não entendem é que o problema não é a separação dele com minha mãe, o problema foi a separação dele com a gente. Porque ele se separou dos filhos depois que se separou da minha mãe. Ele sempre foi um pai ausente, mas isso eu via como normal de uma família tradicional, não que eu concordasse (Alice, 39 anos).

Em relação a sua formação profissional, Alice relatou ser apaixonada pela sua profissão e pelos estudos, o que a fez morar em diversas cidades, tanto para se aprimorar profissionalmente quanto para buscar oportunidades de trabalho, dentre as quais, destaca o consultório na cidade que reside atualmente, onde conheceu Pedro.

A participante relatou ainda que a maternidade sempre foi um desejo e que acredita que o investimento em sua profissão fez com que, antes de conhecer Pedro, ela não tivesse se dedicado a relacionamentos afetivos que levassem a concretização deste desejo. Assim como Pedro, Alice relatou que ambos investiram no relacionamento sabendo que ele não desejava ter filhos, enquanto este era um desejo muito forte dela, o que, segundo ela, o planejamento da gravidez só foi possível depois de diversas conversas e negociações entre o casal:

Bom eu acho que ele vai até te falar, o Pedro não queria ter filhos né e aí a gente teve que conversar sobre isso antes, porque como eu te falei pra mim era uma certeza né, mas eu tive que expor pra ele muitas vezes meus motivos de querer ter um filho, assim como ele me falou o porque não queria. Foi como se fosse assim chegar em acordo, uma negociação mesmo (Alice, 39 anos). 
Alice, atribuiu ainda a esta negociação e também à sua idade o fato dela ter decidido não ter mais filhos. Para ela, negociar com Pedro um segundo filho seria exigir demais dele, uma vez que sabe o quanto este foi um processo de mudanças para ele. Quanto a idade, Alice relatou ainda que considera arriscado, em termos físicos, ter um filho próximo aos 40 anos.

No que diz respeito a sua relação com Isabela, Alice se define como uma mãe bastante participativa e envolvida nos cuidados da filha, relatando assim, o dia-dia com a filha e os principais desafios encontrados:

Acho que ser mãe é um desafio sabe. Não é que eu acho impossível conciliar a rotina do trabalho com a rotina de um filho. $\mathrm{O}$ que eu acho difícil é conciliar isso com qualidade. Chegar em casa cansada e ainda sim dar atenção, carinho, brincar. No dia-dia ela só tem nós dois [Alice e Pedro], não tem um irmão para brincar ou dividir a atenção. De modo geral eu acho que participo bastante viu. Eu brinco muito com ela, converso, programo atividades juntas. Acho que sou bem participativa (Alice, 39 anos).

$\underline{\text { Isabela }}$

Isabela, branca, 6 anos, natural de um município de pequeno porte do interior do estado de São Paulo, cursa a pré-escola e é filha única de Pedro e Alice. Em relação ao seu dia-dia, Isabela relatou que faz inglês e ballet e que gosta muito de brincar com seus pais, destacando que seu pai não brinca com ela o quanto ela gostaria que ele brincasse e que a entristece não poder participar de algumas atividades com ele:

De manhã eu vou brincar, de segunda eu brinco, de terça eu vou no inglês, de quarta eu brinco, de quinta inglês de novo e ballet na sexta.... ele [pai] brinca pouco. Ele gosta bastante de andar de bicicleta mas ele não deixa eu ir junto, aí eu fico triste (Isabela, 6 anos).

Isabela apresenta como integrantes de sua familia: Pedro, Alice e uma prima, com quem tem uma relação bastante próxima e por vezes chama de irmã, apesar de declarar 
que não gostaria de ter irmãos: "eu não [não quero irmãos] eles só ficam choramingando, unhé, unhé, unhé, e eu não ia dividi minhas coisas".

De modo geral, em seu discurso Isabela enfatiza o fato de sua mãe ser paciente e brincar bastante com ela, enquanto seu pai é revelado como alguém que chama muita atenção e não brinca o quanto ela gostaria: “... meu pai fica bravo quando eu não consigo fazer [tarefas escolares]. Minha mãe fala que ele não tem paciência e eu não gosto quando ele fica chamando minha atenção: 'Isabela não faz isso'.

\section{$\underline{\mathrm{O} \text { encontro entre a pesquisadora e a família Campos }}$}

O contato com a família Campos foi realizado incialmente via um membro de minha rede pessoal. Ao obter o telefone de Alice, eu entrei em contato para explicar os objetivos de minha pesquisa e convidar sua familia para participar. Acordamos, mediante sugestão de Alice, que trocaríamos mensagens para decidir a melhor data para sua familia. Após duas semanas trocando mensagens, Alice estabeleceu a data, horário e local -consultório de Alice, a ser realizado o encontro com sua família.

Hoje Alice mandou uma mensagem confirmando nosso encontro. Fiquei feliz com o aceite, mas estou me sentindo apreensiva, pois não conheço a cidade e fico pensando como vou fazer em relação a questões práticas, pois provavelmente passarei o dia com eles. Será que deixei claro que as entrevistas podem demorar? Desde de que comecei a trocar mensagens com ela fico imaginando com eles são [aparência física] e como vão me receber (notas do diário de campo).

No dia combinado, viajei até a cidade onde a Família reside e, quando cheguei ao consultório, as 9 horas da manhã, como combinado, a secretária de Alice pediu pra eu esperar, pois ela havia avisado que estava chegando. Minutos depois Alice chegou com Isabela, pedindo desculpas pelo atraso e perguntou se eu poderia começar a coleta com Isabela, pois ela estava ansiosa. Afirmou ainda que Pedro chegaria mais tarde.

Me senti muito bem recebida. Alice preparou uma sala em seu consultório, com mesa, cadeiras, ventilador, tudo bem aconchegante e reservado. Alice explicou a Isabela que qualquer coisa que eu precisasse ela deveria providenciar. Isabela, antes da entrevista quis me apresentar o consultório e me mostrar seu mural de 
desenhos. Isabela parecia ter percebido que inicialmente eu estava ansiosa e delicadamente mostrando-me seus desenhos foi me fazendo me sentir à vontade (notas do diário de campo).

Comecei então a coleta com Isabela, expliquei-a de forma acessível minha pesquisa e iniciei aplicando o DF. Em seguida, realizei algumas perguntas sobre o desenho e também sobre sua rotina, adaptando, para sua idade, o roteiro de entrevista.

Não imaginava que conseguiria fazer as perguntas do roteiro para Isabela. Devido a sua idade pensei que isto não seria possível e que, como previsto, aplicaria apenas o DF. Isso me fez repensar no meu método, no sentido de que a depender da criança, ainda que esta tivesse menos de 12 anos de idade, como planejado, conseguiria fazer também algumas perguntas do roteiro e deveria estar preparada para isso (notas do diário de campo).

Ao finalizar com Isabela, Alice me convidou para tomar um café, ali mesmo em seu consultório, para em seguida prosseguirmos com ela. Durante o café, Alice me contou sobre a cidade e sobre sua trajetória profissional até chegar na cidade atual. Em seguida, voltamos a sala reservada e iniciamos nossa conversa, em que reiterei os objetivos de minha pesquisa e apresentei o TCLE, aplicando então, os instrumentos na seguinte ordem: Formulários de Dados Sociodemográficos e Critério de Classificação Econômica Brasil e Roteiro de Entrevista Semiestruturado.

Após finalizar com Alice, ela observou que já estava na hora do almoço e então me convidou para irmos a um restaurante almoçar. Voltamos à sala de espera e então fui apresentada a Pedro que estava chegando. Acordamos então que eu conversaria com ele após o almoço.

No caminho para o restaurante fiquei um pouco desconfortável com o silêncio no carro. Neste momento comecei a imaginar se seria assim o almoço todo. O que eu posso falar? Melhor ficar calada? No entanto, Alice e Pedro começaram a contar sobre um show que haviam ido na semana anterior em Ribeirão Preto, e então, naturalmente fomos conversando sobre as cidades e os eventos. Isabela, parecendo mais uma vez perceber que eu estava desconfortável, começou a me contar sobre sua escola e seus amigos (notas do diário de campo). 
Ao retornarmos do almoço iniciei minha conversa com Pedro, em que reiterei os objetivos de minha pesquisa e apresentei o TCLE, aplicando então, os instrumentos na seguinte ordem: Formulários de Dados Sociodemográficos e Critério de Classificação Econômica Brasil e Roteiro de Entrevista Semiestruturado. Em seguida, Pedro ligou para Alice e Isabela avisando que havíamos finalizado e pedindo para que elas retornassem para o consultório para realizarmos, em conjunto, a construção do genograma da famîlia. Feito o genograma eu agradeci cada membro da família Campos e retornei a Ribeirão Preto-SP. A despedida foi breve, pois Pedro e Alice comentaram que retomariam as atividades de trabalho no final da tarde, uma vez que cancelaram os compromissos do período da manhã para me receber.

\subsubsection{Estudo de Caso 2: Família Sampaio}

Quem são os integrantes da família Sampaio? Uma breve apresentação e contextualização

Tabela 3

Caracterização da família Sampaio em termos de integrantes, estado civil, escolaridade ocupação/profissão, idade, religião e classificação socioeconômica.

\begin{tabular}{|c|c|c|c|c|c|c|c|c|}
\hline Família & \multicolumn{2}{|c|}{ Integrantes } & $\begin{array}{l}\text { Tipo de } \\
\text { União }\end{array}$ & Escolaridade & $\begin{array}{l}\text { Profissão/ } \\
\text { Ocupação }\end{array}$ & $\begin{array}{c}\text { Idade } \\
\text { (anos) }\end{array}$ & Religião & $\begin{array}{c}\text { Classificação } \\
\text { Socioeconômica }\end{array}$ \\
\hline \multirow{5}{*}{ Sampaio } & \multirow[t]{2}{*}{ Pais } & Joel & \multirow[b]{2}{*}{$\begin{array}{c}\text { Cas ados } \\
\text { (13 anos })\end{array}$} & $\begin{array}{c}\text { Ensino } \\
\text { Superior } \\
\text { Completo } \\
\end{array}$ & $\begin{array}{c}\text { Engenheiro } \\
\text { Civil }\end{array}$ & 61 & Católica & \multirow{5}{*}{$\begin{array}{c}\mathrm{A} \\
(\mathrm{R} \$ 9.000)\end{array}$} \\
\hline & & $\begin{array}{c}\text { E } \\
\text { Estela }\end{array}$ & & $\begin{array}{c}\text { E } \\
\text { Ensino Médio } \\
\text { Completo }\end{array}$ & $\begin{array}{c}\text { E } \\
\text { Gerente } \\
\text { Comercial }\end{array}$ & 32 & Católica & \\
\hline & \multirow{3}{*}{ Filhos } & André & - & $\begin{array}{c}\text { Ensino } \\
\text { fundamental } \\
\text { (cursando) }\end{array}$ & Estudante & 12 & Católica & \\
\hline & & Augusto & - & $\begin{array}{c}\text { Ensino } \\
\text { fundamental } \\
\text { (cursando) }\end{array}$ & Estudante & 9 & Católica & \\
\hline & & Ângelo & - & $\begin{array}{c}\text { Ensino } \\
\text { Infantil } \\
\text { (cursando) }\end{array}$ & Estudante & 4 & Católica & \\
\hline
\end{tabular}


A Familia Sampaio é constituída por Joel (pai), Estela (mãe) e os três filhos do casal: André, 12 anos; Augusto, 9 anos e Ângelo, 4 anos. Joel, 61 anos, engenheiro civil, atua em projetos particulares na área da construção civil. Estela, 32 anos, gerente comercial, trabalha em uma loja de materiais de construção. Quanto aos filhos do casal, os três estudam em uma escola particular do município no período da tarde.

Joel e Estela se conheceram há pouco mais de 14 anos, em uma loja de conveniências onde Estela trabalhava, e estão casados há 13 anos. A Família Sampaio reside em casa própria, na cidade natal de Joel e Estela, localizada no interior de São Paulo. Em relação a religião, a familia se autodenomina católica e destaca que frequenta a igreja ao menos uma vez na semana.

Como também é possível observar, a familia pertence ao nível socioeconômico A de acordo com o Critério de Classificação Econômica Brasil, o que os coloca entre os 2,9\% da população brasileira pertencente a esse nível econômico, o mais alto da escala desenvolvida pela ABEP (2015). Destaca-se que a renda mensal familiar encontrada foi, em média, de 9 mil reais mensais, sendo que destes, 7 mil referem-se à renda de Joel e 2 mil referem-se à renda de Estela.

A seguir será apresentado o Genograma da Familia Sampaio:

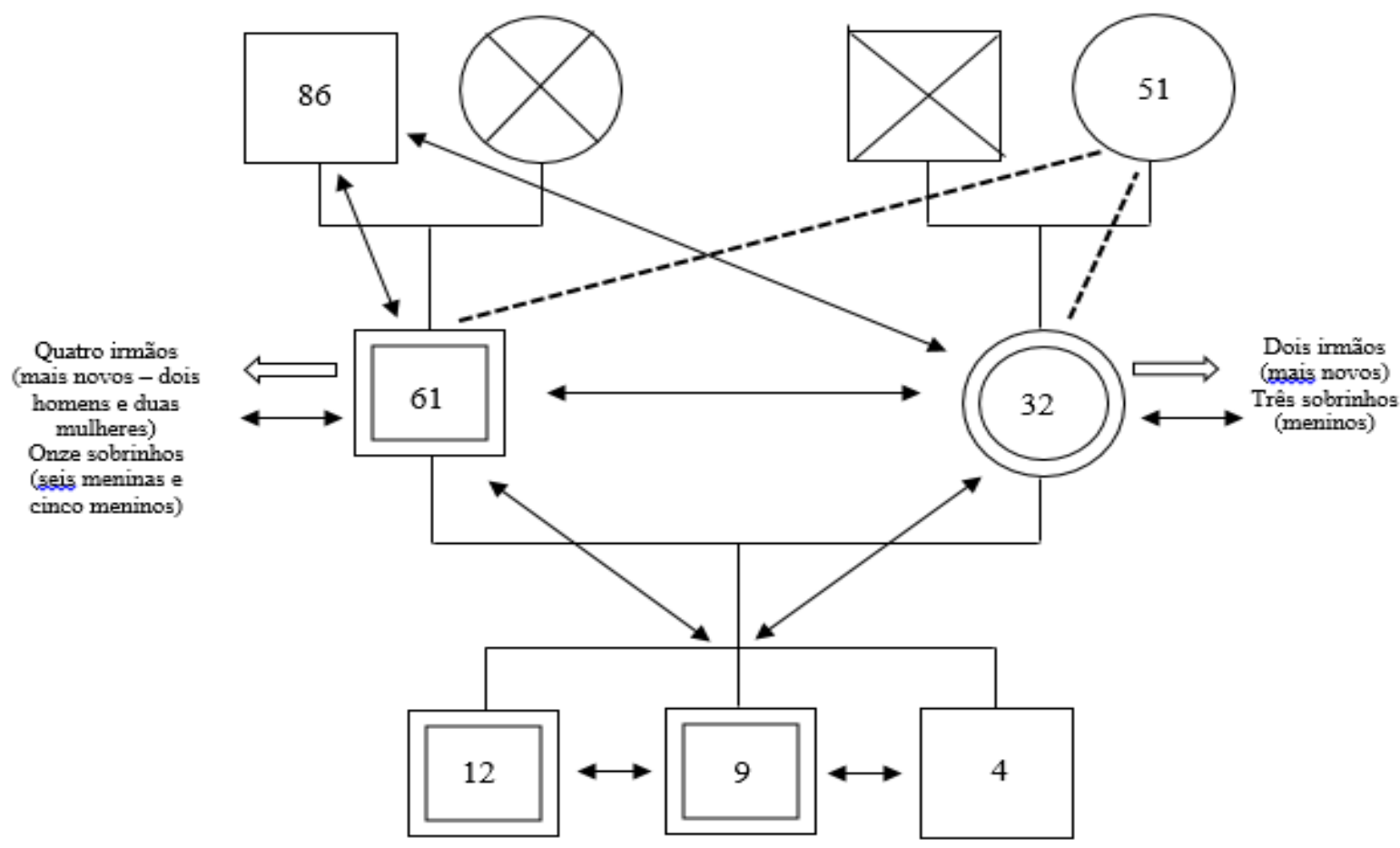

Figura 2. Genograma da Família Sampaio 
$\underline{\text { Joel }}$

Joel, branco, 61 anos, engenheiro civil, natural e residente de um pequeno município do interior do estado de São Paulo, é o filho primogênito de uma familia constituída por pai, mãe (falecida) e cinco filhos, sendo três homens e duas mulheres. No que tange aos seus irmãos, Joel relata que sempre possuiu um relacionamento amigável e afetivo com todos, no entanto, destaca que este relacionamento parece ter melhorado ainda mais após a chegada de seus filhos, principalmente na questão de proximidade física e no desejo de estar junto a eles:

Meus irmãos casaram bem mais cedo né, eles tinham a familia deles e você acaba se isolando, não tem mais como participar da vida deles. Então tudo o que eles iam fazer eles iam com a família, como eu não tinha, era solteiro, acabava ficando meio deslocado, me sentia afastado. Hoje não, hoje levo meus filhos pra eles verem, eles vem na minha casa. Digamos assim que tenho histórias em comum para contar (Joel, 61 anos).

Em relação aos seus pais, Joel relatou um vínculo muito forte tanto com sua mãe (falecida) e com seu pai. Ao falar de sua mãe, Joel a define como cuidadora, carinhosa e sábia. O pai é relatado como alguém bastante rígido com os filhos, mas que ao longo da vida se tornou seu grande amigo e companheiro. Joel revela que o fato de ter se casado na meia-idade, ainda que em sua percepção as vezes apresente desvantagens, the proporcionou momentos ímpares com seus pais, principalmente por ter morado com eles até o dia em que se casou:

Eu me sentia o amigo dele sabe! Quando eu tinha quase uns 40 anos, eu achava que não ia me casar e ter filhos, que não dava tempo mais, mas não via graça ir para as baladas, em sair. Foi então que me aproximei ainda mais do meu pai. Ele se tornou meu amigo e companheiro. Íamos para bares juntos, assistíamos TV juntos.... Claro que eu podia morar sozinho e sair de lá, mas eu não sentia que aquilo era imaturidade não, eu queria curtir eles (Joel, 61 anos).

No que diz respeito a sua relação com Estela, Joel relata que acreditava que não iria se casar e ter filhos e que conhecê-la foi uma surpresa em todos os sentidos. Ele 
destaca os desafios do relacionamento, como, por exemplo, o preconceito sofrido em relação a diferença de idade de ambos, principalmente por parte da mãe de Estela, mas também relata a admiração que tem pela sua esposa, suas qualidades e o quanto a vida a dois fez com que as dificuldades se tornassem menores do que as alegrias:

Nós não brigamos quase nunca sabe. Claro que nos desentendemos, mas nunca brigas feias. Eu admiro ela e o principal é a paz que vivemos. Eu não imaginava que daria tempo de ter filhos, ainda mais de três (risos). Nós vivemos bem e isso me faz querer voltar para casa todos os dias.... Claro que ficamos triste com o fato da mãe dela não aceitar muito bem nossa relação. Mas sabe de uma coisa? Eu entendo a mãe dela, a Estela é a única filha mulher, ela deve ter sonhado que ela se cassasse com alguém mais novo. Talvez ela tenha medo da Estela ficar sozinha, devido a minha idade. Entendo mesmo sabe. Não vou mentir pra você, muitas vezes até eu achei que eu estava sendo egoísta. Mas hoje olho pra nossa vida e sinto que ela é feliz, que somos felizes. Talvez seja isso que as pessoas que estão de fora não consigam ver não é mesmo? (Joel, 61 anos).

A respeito da paternidade, Joel revelou que se sente realizado com seus filhos e que se esforça a cada dia para ser um pai melhor e mais presente na vida destes. Em seu discurso, destaca a importância que atribui aos momentos que passa junto aos seus filhos e o quanto acredita que isso torna a relação satisfatória e prazerosa:

Eu estou em casa toda hora, então tomamos café da manhã juntos. Fazemos tudo juntos. Eu procuro, acho importantes esses momentos, você almoçar; jantar junto. Isso traz união entre a família e eu acredito que um pai precisa ser assim sabe, presente na vida dos filhos, desde as pequenas coisas até as grandes (Joel, 61 anos).

Ao falar sobre o quanto tenta a cada dia ser um pai melhor, Joel destaca que tem conseguido se fazer bastante presente nas vidas dos filhos, no entanto, relata que em termos afetivos, ainda que tente ser mais carinhoso, percebe que é um pai por vezes rígido, o que impede, em sua percepção, momentos de expressão de afeto com seus filhos. 
Sabe eu tento não ser, mas as vezes me acho um pai seco e rígido demais. Eu luto contra isso viu, mas não é fácil. Eu tento a cada dia mudar isso, mas quando vejo aconteceu da forma que eu não queria. Não sei se foi minha criação. Você deve saber disso né? (Joel, 61 anos).

\section{$\underline{\text { Estela }}$}

Estela, branca, 32 anos, gerente comercial, natural de uma cidade localizada interior do estado de São Paulo, é a filha mais velha de uma família constituída por pai (falecido), mãe e três filhos, sendo uma mulher e dois homens. Em seu discurso, a participante relatou que possui um relacionamento harmonioso com seus irmãos e seus sobrinhos, destacando que apesar de morarem em cidades diferentes e isso reduzir a possibilidade de contato físico, não considera que a distância afete o relacionamento e a proximidade afetiva.

No que diz respeito ao relacionamento com sua mãe, Estela o define como distante, relatando assim diversos episódios que, segundo ela, contribuíram para este distanciamento afetivo e físico ao longo dos anos:

Por ser a filha mais velha sinto que minha mãe sempre cobrou muito de mim sabe. $\mathrm{Eu}$ era aquela que tinha que cuidar dos meus irmãos, que tinha que trabalhar, namorar, casar e ter filhos. Mas tudo isso tinha que ser do jeito dela. Aí sempre tivemos conflitos por conta destas cobranças. Agora o que foi o pior, foi quando conheci o Joel. Ela não aceitou e não aceita até hoje. Todo mundo me fala pra eu me colocar no lugar dela e tentar entender. Claro que eu sei que ele é mais velho que ela, que ela queria me ver casar de véu e grinalda, que ela acha que vou criar meus filhos sozinha. Entendo tudo isso. Mas essa é minha escolha e eu sou feliz. Não aceito ela desrespeitar minha família e o que eu construí. Ela está abrindo mão de participar da minha vida sem ao menos tentar entender o que sinto (Estela, 32 anos).

Ainda a respeito do relacionamento com sua mãe, Estela afirma que há algum tempo o definiria como conflituoso, mas que atualmente o considera distante, uma vez que, optou por se afastar da mãe para evitar conflitos explícitos, tendo assim, raros encontro e conversas com essa: 
É claro que dói, dói muito. Mas minha familia está aqui. O que ela quer que eu faço? Volte no tempo. Não dá. Não dá também porque eu sou feliz. Aprendi respeitar o que ela pensa e acho que ela precisa respeitar o que eu construí. Enquanto isso, a distância foi a única forma que encontrei para isso não doer ainda mais (Estela, 32 anos).

No que tange ao seu casamento, Estela o define como harmonioso e baseado na segurança e confiança. A participante define Joel como um homem maduro e muito responsável em relação a paternidade, dando destaque para o momento em que lhe contou sobre gravidez:

Eu brinco que o Joel me tornou inconsequente sabe (risos), mas acho que a maturidade dele fez com que tudo ficasse natural. Não planejamos o André, mas quando contei para o Joel que estava grávida, eu estava assustada e ele me disse assim: 'Mas nós sabíamos que havia esta possibilidade, nós não estávamos nos prevenindo'. Não é que ele seja tranquilo, é que acho que ele é tão maduro que nunca passou pela cabeça dele que aquilo era responsabilidade só minha, como eu vejo que acontece como muitos casais que estão juntos há poucos meses e isso acontece.... Nos outros relacionamentos que tive, não me sentia segura nem pra falar da possibilidade de engravidar (Estela, 32 anos).

Em seu discurso, Estela destaca que além da sua mãe, já ouviu diversas pessoas comentando sobre a diferença de idade entre ela e Joel. A este respeito, a participante destaca que entende o fato de algumas pessoas demonstrarem espanto por tal diferença e consegue lidar bem com isso. No entanto, ela relata que existe uma grande diferença entre espanto e desrespeito, destacando que, o segundo a magoa bastante:

Olha, se você me falar: 'Nossa Estela, mas é muita diferença né, você não pensa nisso?' Eu não vou me magoar com você, eu vou responder o que penso, mas que existem outras coisas no meu relacionamento que tornam esta diferença insignificante. Agora, o que mais me magoa é as pessoas que não tentam escutar o que eu penso, o que eu vivo e saem logo me julgando, julgando meu marido (Estela, 32 anos). 
Ainda a respeito do seu relacionamento, para além da maturidade de Joel e do quanto ela acredita que sua idade contribui pra que ela se sinta mais segura, Estela destaca uma rotina na qual ela considera comum em termos de alguns desentendimentos, discordâncias e desafios em conciliar a vida conjugal com a parentalidade:

Vivemos uma vida de casal que eu considero normal. Nos desentendemos como todos os casais, não concordamos em algumas coisas.... Acredito que um dos principais desafios é conciliar a vida de casados com a vida de pais viu, até mesmo a vida no trabalho. Acho que isto é o mais difícil, conciliar a rotina com os filhos e momentos a dois, mas acho que estamos indo bem (Estela, 32 anos).

Em relação aos filhos, Estela se define com uma boa mãe, caracterizando assim o relacionamento com os mesmos como harmonioso. Em seu discurso, ela apresenta o desejo de ter mais tempo para ficar com eles, tempo este que, por vezes ela parece definir como sinônimo de tranquilidade:

Tranquilidade para viver esses momentos. Apesar de vivermos, as vezes é sempre correndo, a correria do dia-dia mesmo. Às vezes sinto falta de ter mais tempo para ficar com eles, mas tem sempre uma coisa interrompendo.

\section{$\underline{\text { André e Augusto }}$}

André, 12 anos, e Augusto, 9 anos, cursam o ensino fundamental na mesma escola e possuem uma rotina bem similar. Ambos estudam no período da tarde e duas vezes na semana fazem inglês no período da manhã. Quando estão em casa, costumam jogar videogame juntos ou ficar em seus respectivos quartos fazendo lição de casa e mexendo no celular.

Em relação as atividades em familia, ambos destacam que costumam sair para jantar e visitar outros familiares. André relata um desejo de realizar mais atividades com seus pais, no entanto, não soube expressar quais seriam estas atividades:

É normal eu me sentir meio mal? Eu estou sentido como se eu quisesse fazer mais coisas com eles, mas eu não sei que tipo de coisa eu faria com eles, porque a maioria das vezes eles estão trabalhando e nos estudando (André, 12 anos). 
Ainda a respeito das atividades, Augusto relata a participação dos pais na sua rotina, destacando as atividades que cada um desempenha no dia-dia e atribuindo ao pai a maior participação nas atividades diárias:

Meu pai leva e busca a gente na escola. Minha mãe não pode fazer isso porque no trabalho dela ela não pode sair. Meu pai também busca pão e toma café da manhã com a gente, né André? Tem vezes que a gente ajuda ele digitar umas coisas no computador também. A noite ele também põe a gente pra dormir. Minha mãe faz a comida né (Augusto, 9 anos).

No que tange as relações familiares, André e Augusto relatam que às vezes eles se desentendem devido à organização das coisas que eles deixam espalhadas pela casa e também por conta do videogame. Ambos relatam se incomodar com os choros e birras do irmão menor e com o fato de, algumas vezes, seus pais solicitarem que ajudem a cuidar dele.

André e Augusto definem a mãe como sendo carinhosa, atenciosa, porém bastante ocupada. O pai, por sua vez, é definido por ambos como alguém bastante participativo, no entanto, ao relatar os momentos de interação com o pai, enquanto Augusto dá destaque ao café da manhã que eles realizam juntos todos os dias e os momentos antes de dormir, André destaca os momentos em que o pai fica bravo e costuma chamar atenção ou até mesmo bater quando eles fazem algo que o desagrada.

\section{$\underline{\mathrm{O} \text { encontro entre a pesquisadora e a família Sampaio }}$}

A família Sampaio tem como membro Joel, um dos pais que já havia participado de minha pesquisa de iniciação científica. Deste modo, retomei meus arquivos e tentei contato telefônico com Joel, no entanto, não obtive sucesso, pois aparentemente o número que eu tinha não estava mais sendo utilizado. Foi então que enviei um e-mail e após seis dias recebi a resposta deste, informando-me o número de sua esposa e pedindo para que eu entrasse em contato com ela.

Ao entrar em contato com Estela, assim que me apresentei ela logo disse que Joel já the havia contado que provavelmente eu ligaria. Durante toda a conversa telefônica ela se mostrou muito solícita e me informou que o melhor dia da semana para eu realizar as 
entrevistas seria aos sábados, pois todos estariam em casa. Terminamos a conversa com o combinado de que ela me retornaria dizendo a melhor data para a família. Foi então que, após uma semana, Estela me ligou dizendo que eu poderia ir até a casa da família no sábado da semana seguinte, pedindo para eu ligar para ela quando chegasse na cidade.

No dia anterior à viagem, confirmei com Estela minha ida e o horário aproximado de chegada, por volta das 9 e 30 horas. Quando cheguei a cidade, liguei para Estela avisando que logo estaria na casa deles. Durante a ligação, ela me questionou onde eu estava e, ao ser informada de que eu estava na rodoviária e pegaria um táxi, Estela disse que fazia questão de me buscar, descrevendo as características de seu carro para que pudesse reconhecê-la.

Fiquei um pouco constrangida com o fato de Estela se dispor a me buscar na rodoviária, no entanto, ela foi tão solícita e se ofereceu tão prontamente que não consegui recusar. Poucos minutos depois ela chegou e disse: "Mayara é você?" Então eu entrei no carro e ela logo emendou a conversa: "Como é bom ver a pessoa né. A tecnologia é ótima, mas adoro conhecer as pessoas pessoalmente. Os meninos estão ansiosos para conhecer você” (notas do diário de campo).

Neste momento pensei o mesmo, como é bom ver alguém que já havia imaginado há pouco mais de três anos, quando entrevistei Joel e ele relatava sobre sua esposa. Não, ela não era do jeito que eu imaginei. Não na aparência física, mas muito simpática e alegre, como nos telefonemas (notas do diário de campo).

Ao chegar na casa da Família Sampaio, Joel e seus filhos estavam nos esperando na sala e, ao me ver, André logo disse: 'Ufa, ainda bem que ela chegou, eu estou morrendo de fome". Foi então que Estela me convidou a ir à cozinha e, ao entrar, me deparei com uma mesa de café da manhã preparada com cuidado. Fui convidada a sentarme com a família.

Nos primeiros segundos eu fiquei um pouco sem saber o que fazer ou dizer, mas logo André, de modo bastante engraçado, continuou a fala da sala, dizendo que Ester havia proibido eles tocarem nos alimentos até que eu chegasse e que ele estava "verde de fome". Todos nós riamos das falas de André e do fato de Estela parecer envergonhada com o que ele dizia. Foi um momento de muita 
descontração e fantástico pra mim, pois eu pude ver e participar de um momento de interação da família (notas do diário de campo).

Após o café, Estela sugeriu que eu começasse a coleta com Joel, alegando que no dia anterior ele já havia dito que gostaria de ser o primeiro. Desta forma, iniciei a coleta de dados, (re)explicando inicialmente os objetivos de minha pesquisa, apresentando o TCLE, e, em seguida, aplicando os instrumentos na seguinte ordem: Formulários de Dados Sociodemográficos e Critério de Classificação Econômica Brasil e Roteiro de Entrevista Semiestruturado.

Ao finalizar com Joel, o mesmo sugeriu que prosseguisse a coleta com André e Augusto, pois, segundo ele, Estela já estava envolvida nos preparativos do almoço. Destaca-se que dos três filhos do casal, dois, André e Augusto, se enquadravam nos critérios de inclusão da pesquisa. Durante a conversa no telefone Estela já havia me adiantado que Augusto era muito tímido e não sabia se ele aceitaria conversar comigo. Assim, diante da timidez de Augusto, Joel sugeriu que eu fizesse a entrevista com os dois irmãos juntos e assim foi feito.

Inicialmente fiquei com receio de fazer a coleta com ambos, André e Augusto, juntos. Questionei-me se isso poderia causar algum prejuízo para minha pesquisa; se André não iria inibir ainda mais Augusto, sobressaindo-se. No entanto, ao observar a timidez de Augusto e o fato de seus comentários acontecerem sempre após alguma fala de André, como se este o encorajasse, tomei a decisão de acatar a sugestão de Joel, com base na consideração da importância de ouvir os dois e de perceber que isso só seria possível se eu o fizesse conjuntamente (notas do diário de campo).

Iniciei a coleta explicando a André e Augusto, de modo acessível, os objetivos da minha pesquisa e, então, ato contínuo, prossegui com as perguntas do roteiro de entrevista. A medida que André ia respondendo, ele estimulava o irmão a falar também e, poucos minutos depois, a entrevista fluiu naturalmente, sendo que um completava o que o outro dizia ou respondia aquilo que percebia. Em seguida, apliquei o DF. Optei aqui, por aplicar o DF nos dois, ao invés de apenas em Augusto, pois considerei que seria mais adequado. 
Augusto inicialmente se recusou a fazer o desenho e quando o fez, logo rabiscou e rasgou. Mesmo com algumas tentativas, apenas André aceitou a aplicação do DF e conseguiu finalizar o mesmo, uma vez que Augusto alegava que estava feio e não conseguiria fazer.

No momento em que Augusto rabiscou o desenho e rasgou eu fiquei bastante decepcionada e até mesmo frustrada. No entanto, ao tentar conversar com ele do porquê dele não querer realizar o desenho, recordei-me de sua timidez, relatada diversas vezes por Estela e Joel. Mesmo diante de sua timidez, ele já havia respondido algumas perguntas e arriscado a iniciar o desenho. Não seria muita invasão insistir para que ele prosseguisse no DF? Não se tratava de uma simples recusa ou birra, mas sim dele mostrando para mim aquilo que seus pais já haviam me alertado. Foi então que optei por não insistir que ele prosseguisse com o desenho (notas do diário de campo).

Ao finalizar a entrevista com os filhos do casal, por volta da 12:30 horas, fui convidada para almoçar.

Ao entrar na cozinha vi que a refeição já estava à mesa e havia seis pratos colocados. Neste momento tive a certeza que a familia havia organizado todo o seu dia para me receber. $\mathrm{O}$ almoço, assim como o café, foi muito agradável. Todos pareciam empenhados em me deixar confortável. André, de forma muito bem humorada, disse: "Mayara, você promete que vem mais vezes? Assim minha mãe faz essas comidas boas de novo". Todos nós rimos da fala de André. Joel também brincou com Estela, "Fala verdade vai, você cozinha todos os dias, mas este capricho" (notas do diário de campo).

Em seguida, dei continuidade à coleta de dados com Estela, reiterando, assim como com Joel, os objetivos de minha pesquisa, apresentando o TCLE e, aplicando então, o Roteiro de Entrevista Semiestruturado. Ao finalizar a entrevista, foi o momento da construção do genograma da familia, que contou com a colaboração de Joel e Estela e também dos filhos do casal, que ficaram no mesmo ambiente.

Destaca-se que a aplicação dos instrumentos com Joel e Estela foi realizada no escritório da casa, enquanto que, André e Augusto, optaram por fazer a entrevista no 
quarto do primeiro. Finalizada a coleta, me despeço da familia e, Estela, novamente, faz questão de me levar à rodoviária, certificando-se do próximo ônibus disponível. Nesse momento, André nos acompanha.

\subsubsection{Estudo de Caso 3: Família Azevedo}

Quem são os integrantes da família Azevedo? Uma breve apresentação e contextualização

Tabela 4

Caracterização da família Azevedo em termos de integrantes, estado civil, escolaridade ocupação/profissão, idade, religião e classificação socioeconômica

\begin{tabular}{|c|c|c|c|c|c|c|c|c|}
\hline Família & \multicolumn{2}{|c|}{ Integrantes } & $\begin{array}{l}\text { Tipo de } \\
\text { União }\end{array}$ & Escolaridade & $\begin{array}{l}\text { Profissão/ } \\
\text { Ocupação }\end{array}$ & $\begin{array}{l}\text { Idade } \\
\text { (anos) }\end{array}$ & Religião & $\begin{array}{c}\text { Classificação } \\
\text { Socioeconômica }\end{array}$ \\
\hline \multirow{3}{*}{ Azevedo } & \multirow[b]{2}{*}{ Pais } & Paulo & \multirow[b]{2}{*}{$\begin{array}{c}\text { Casados } \\
(24 \text { anos })\end{array}$} & $\begin{array}{l}\text { Ensino } \\
\text { Superior } \\
\text { Completo } \\
\text { com pós- } \\
\text { graduação }\end{array}$ & $\begin{array}{c}\text { Engenheiro } \\
\text { Agrônomo/ } \\
\text { Professor } \\
\text { Universitário }\end{array}$ & 53 & Católica & \multirow{3}{*}{$\begin{array}{c}\mathrm{A} \\
(\mathrm{R} \$ 20.000)\end{array}$} \\
\hline & & $\begin{array}{c}\text { E } \\
\text { Pâmela }\end{array}$ & & $\begin{array}{c}\text { E } \\
\text { Ensino } \\
\text { Superior } \\
\text { Completo } \\
\text { com pós- } \\
\text { graduação }\end{array}$ & $\begin{array}{c}\text { Engenheira } \\
\text { Agrônoma/ } \\
\text { Professora } \\
\text { Universitária }\end{array}$ & 46 & Católica & \\
\hline & Filha & Vitória & - & $\begin{array}{c}\text { Ensino } \\
\text { Fundamental } \\
\text { (cursando) }\end{array}$ & Estudante & 12 & Católica & \\
\hline
\end{tabular}

A Familia Azevedo é constituída por Paulo (pai), Pâmela (mãe) e Vitória (filha do casal). Paulo, 53 anos, engenheiro agrônomo, trabalha como professor universitário em uma universidade pública há 18 anos. Pâmela, 46 anos, também engenheira agrônoma, trabalha como professora universitária, na mesma universidade pública que Paulo, há 11 anos. Vitória, 12 anos, é estudante do ensino fundamental em uma escola particular. 
Paulo e Pâmela se conheceram na universidade, onde Paulo estava finalizando a pós-graduação e Pâmela um curso de graduação. Após dois anos de namoro, ambos se casaram. Já completam pouco mais de 24 anos de casados. Atualmente, a familia Azevedo reside em uma casa própria em uma cidade no interior de São Paulo, onde Paulo e Pâmela lecionam. Em relação a religião, eles se autodenominam católicos e destacam que frequentam a igreja ao menos uma vez na semana.

Como também é possível observar a famîlia pertence ao nível socioeconômico A de acordo com o Critério de Classificação Econômica Brasil, o que os coloca entre os 2,9\% da população brasileira pertencente a esse nível econômico, o mais alto da escala desenvolvida pela ABEP (2015). Destaca-se que a renda mensal familiar é de 20 mil reais mensais, sendo que destes, 10 mil referem-se à renda de Paulo e 10 mil referem-se à renda de Pâmela.

A seguir será apresentado o Genograma da Familia Azevedo:

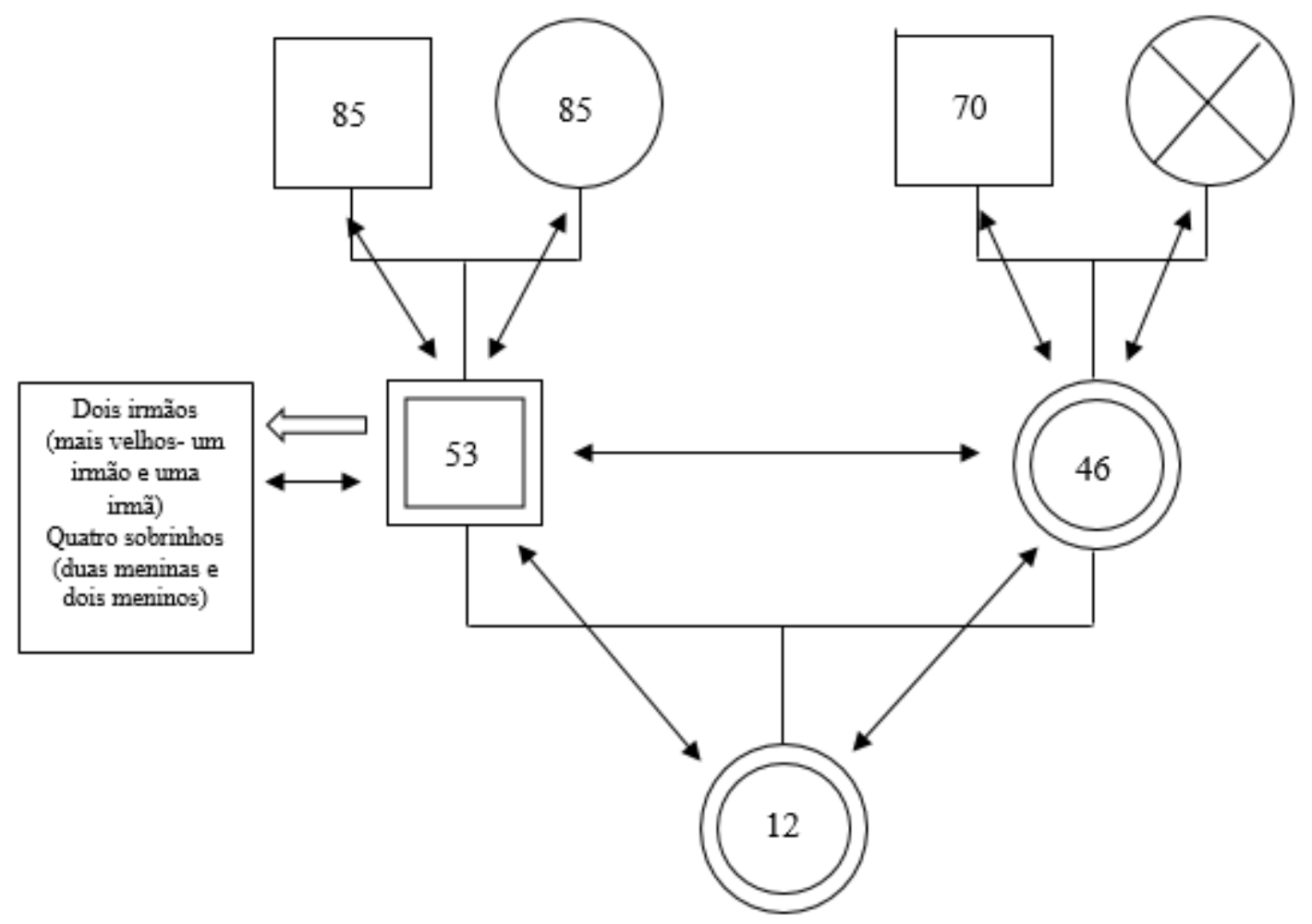

Figura 3. Genograma da Família Azevedo 
$\underline{\text { Paulo }}$

Paulo, branco, 53 anos, engenheiro agrônomo, trabalha como professor universitário em uma universidade pública há 18 anos, é o filho caçula de uma família constituída por pai, mãe e três filhos, sendo dois homens e uma mulher. Em seu discurso, Paulo destacou o nascimento de Vitória como marco de mudanças em suas relações familiares:

Eu acho que foi depois do nascimento dela que ficamos mais chegados. Antes a gente quase não se via. Depois que ela nasceu, meus pais, a minha mãe, meus irmãos, começaram a vir mais em casa, meu pai mesmo adora vir em casa. Antes, eles não vinham, até porque a gente vivia trabalhando e mesmo se alguém viesse, a gente não ia estar aqui, porque a gente viajava muito. Hoje, somos bem próximos (Paulo, 53 anos).

No que diz respeito a seus pais, Paulo retomou vivências da infância para explicar o modo como cada um deles se relacionava com os filhos, definindo assim, de modo geral, seu pai como "sisudo" e sua mãe como amiga e carinhosa:

Não tinha uma relação amistosa: pai era pai, filho era filho, sabe? Meu pai ele era um pai bastante novo né, então ele jogava bola, ele brincava de carrinho, ele era uma criança, só que ele era um cara sisudo, ele não era um cara que abraçava e beijava.... Minha mãe não, minha mãe era amiga da gente, dava carinho, conversava com a gente, ensinava a gente, falava, e colocava na cabeça da gente coisas que ela queria que a gente fizesse, estudar, por exemplo (Paulo, 53 anos).

Quanto a vivência da parentalidade, Paulo relatou que ele e sua esposa não pretendiam ter filhos, mas que, apesar de não ter sido planejado, o nascimento de Vitória foi uma surpresa maravilhosa na vida do casal:

Não foi um processo, foi um acidente, muito bom e maravilhosos por sinal. A gente não tinha planejado ter filho. A nossa ideia não era ter filho, só que devido ao histórico de câncer de mama na famîlia, o médico dela orientou ela parar de tomar pílula, alegando que por conta da idade e do tempo que ela tomava, ela teria 
dificuldade para engravidar. Parou de tomar a pilula, um mês depois estava grávida (risos). No começo a gente assustou, mas depois, foi a melhor coisa que aconteceu na nossa vida (Paulo, 53 anos).

Em relação a paternidade, Paulo se define como um pai carinhoso e participativo, no entanto, em seu discurso, verificou-se que esta participação está mais relacionada aos momentos de lazer do que ao cuidado da filha em si, uma vez que, Paulo relatou acerca de uma divisão de cuidados entre ele e a esposa:

Hoje pela adolescência dela está bastante complicada. Hoje se a gente se aproxima, logo ouve um "sai pra lá, pai" e tal, não sei o que e tal. Mas é normal, né, adolescência dela, quer ficar mais no quarto, fazer as coisa delas. Mas eu acho que sempre participei muito. Acho que mais nas atividades de lazer. A Pâmela acaba que sempre cuidou mais né. Banho, troca, pentear o cabelo, levar na escola, no médico. Acho que por ela ser menina e acho que por ser comum a mãe cuidar mais.

Ainda que a concepção de participação de Paulo esteja relacionada aos momentos de lazer da filha, verificou-se que ao se avaliar enquanto pai, ele parece tentar se distanciar do modelo recebido do próprio genitor e, ainda que não se envolva nos cuidados da filha, reflete bastante sobre o demonstração de afeto em relação a ela "Eu acho que sou bem carinhoso, eu tento ser diferente do meu pai nisso sabe, acho que isso eu consigo sabe, abraçar, beijar.

\section{Pâmela}

Pâmela, branca, 46 anos, engenheira agrônoma, trabalha como professora em uma universidade pública há 11 anos, é filha única de uma família composta por ela, seu pai e sua mãe (falecida há 20 anos). Em seu discurso a participante relata o quanto o falecimento de sua mãe, quando ela ainda era jovem, contribuiu em sua decisão inicial de não ter filhos:

É engraçado né, eu podia te dizer que quando minha mãe faleceu, tudo que eu mais queria era ter irmãos, pessoas pra eu dividir meu sofrimento e que isso me 
fez desejar ter uma família enorme. Mas não foi assim, sabe o que ficou na minha cabeça? Que eu não queria ter filhos e correr o risco de deixar eles, como aconteceu comigo. Foi por isso que eu acho que antes não queria ter filhos (Pâmela, 46 anos).

Ainda a este respeito, Pâmela relatou que com a chegada de Vitória, o medo deixa-la sozinha, caso algo the aconteça, ainda se faz presente. Neste aspecto, a participante enfatizou suas reflexões acerca da familia que construiu e de seus desejos em relação a esta:

É maravilhoso ser mãe, mas ainda sinto medo de deixar ela sozinha. Na verdade a perda da minha mãe inicialmente me fez desejar não ter filhos, mas depois, com a chegada da Vitória, fico pensando que acabei construindo uma família pequena igual a minha e que talvez na verdade eu desejasse sim ter filhos, mais que um inclusive, pois ela não estaria sozinha como eu fiquei caso nós faltássemos. Meio confuso né? Mas acho que você entende (Pâmela, 46 anos).

No que tange ao relacionamento com seus pais, Pâmela não só destacou momentos da infância para caracterizar cada um deles, como também enfatizou o modo como a relação com seu pai mudou após o falecimento de sua mãe:

Acho que como quase todas as pessoas da minha geração, eu tive uma mãe que era responsável pelos meus cuidados. Uma mãe carinhosa, atenciosa, que cuidava de mim em tempo integral, me levava na escola.... E um pai mais bravo sabe, que trabalhava fora para colocar comida em casa, chegava cansado e não tinha tempo, não tinha jeito pra brincar comigo.... Mas depois que minha mãe faleceu, eu já era uma mulher, ficou só eu e ele, ela se foi, os tempos mudaram também né. Hoje ele é um avô babão e um pai super carinhoso e próximo de mim (Pâmela, 46 anos).

Ao falar sobre seu pai, Pâmela também refletiu sobre o modo como seu esposo exerce a paternidade, apontando aspectos positivos e aspectos que deseja que ele mude: 'Eu acho que esta parte do carinho, do afeto, ele já é bem diferente que nossos pais, mais brinco com ele, que ainda falta algumas coisas, pincipalmente nos cuidados, muita coisa ainda sobra só pra mim viu.” 
$\underline{\text { Vitória }}$

Vitória, 12 anos, filha única do casal, é estudante do ensino fundamental em uma escola particular. Em relação ao seu dia-dia, a participante relatou que além das atividades relacionadas à escola, faz inglês, natação, e aos finais de semana costuma ir ao cinema com amigas ou se reunir em casa com elas. Quanto as atividades em familia, Vitória destacou passeios de final de semana na casa de familiares, almoços e jantares em restaurantes.

No que tange ao relacionamento afetivo e as atividades realizadas com seus pais, Vitória definiu sua mãe como sendo carinhosa e paciente, e seu pai como carinhoso, porém impaciente. Destacou ainda que, sua mãe é quem participa mais de suas atividades diárias, enquanto seu pai está mais presente nos momentos de lazer:

Minha mãe me leva e busca na escola, na natação, no inglês, me leva no médico, compra roupas. Ela faz quase tudo eu acho, meu pai dá mais atenção de final de semana, ai gente sai pra comer, ir no cinema, essas coisas né.... Os dois são carinhosos, mas ela tem mais paciência comigo do que ele, ele é sem paciência, nervoso eu acho (Vitória, 12 anos).

Ainda em relação ao modo como seu pai exerce a paternidade, Vitória relatou o desejo de que ele participasse mais de suas atividades "Além da paciência que eu queria que ele tivesse (risos) eu queria que ele ficasse mais em casa, me levasse na natação, estas coisas."

\section{$\underline{\mathrm{O} \text { encontro entre a pesquisadora e a família Azevedo }}$}

O contato com família Azevedo foi realizado incialmente via um membro de minha rede pessoal. Ao obter o telefone de Pâmela, eu entrei em contato para explicar os objetivos de minha pesquisa e convidar sua família para participar. Dois dias após este primeiro contato, Pâmela me informou do aceite da família, no entanto, relatou a dificuldade de conciliar uma data em que todos pudessem estar disponíveis, sugerindo assim, que a coleta fosse realizada via Skype, pois, desta forma, poderia ser realizada de acordo com a disponibilidade de cada membro da família. 
Durante a escrita e desenvolvimento do meu projeto eu não havia pensado na possibilidade de realizar a coleta de dados via Skype, ainda que eu soubesse que atualmente era um meio bastante utilizado. Havia planejado ir até as familias, independente da distância. Acho que além da dificuldade de conciliar datas, uma vez que eu me ofereci para ir em um final de semana, Pâmela parece estar receosa em me receber, o que eu considero natural, pois eles não me conhecem. Depois de refletir, optei por respeitar sua decisão e tentar realizar a coleta de acordo com sua sugestão (notas do diário de campo).

A coleta de dados, deste modo, foi realizada em quatro dias diferentes, de acordo com a disponibilidade de cada um dos membros da família. Foi acordado com Pâmela que ela me confirmaria a data e horário que cada um dos membros da família realizaria a chamada para mim, e que os TCLEs (enviados previamente por e-mail) seriam enviados via correio.

Comecei então a coleta de dados, realizando a aplicação dos instrumentos primeiramente com Pâmela, em que reiterei os objetivos e apliquei os instrumentos na seguinte ordem: Formulários de Dados Sociodemográficos e Critério de Classificação Econômica Brasil e Roteiro de Entrevista Semiestruturado. O segundo membro a ser entrevistado foi Paulo, em que segui a mesma ordem de aplicação de Pâmela. Em um terceiro momento, realizei a coleta com Vitória, em que expliquei-a de forma acessível minha pesquisa e realizei as perguntas do roteiro de entrevista.

Apesar de todo a minha insegurança inicial, acredito que consegui realizar a coleta de modo satisfatório. É claro que foi uma experiência bem diferente da tida com as outras três famílias. No entanto, foi um "encontro" único assim como os demais e, de uma riqueza de dados e informações, que a medida em que eu os ouvia, esquecia totalmente da tela do computador e da distância que me separava da família Azevedo (notas do diário de campo).

Percebi que a família foi muito cautelosa em organizar a data e o momento da coleta. Durante as chamadas de vídeo, não houve nenhuma interrupção na coleta. Cada membro da familia realizou a chamada de um cômodo da casa, o que aparentemente pareceu ser o local que cada um considerou ser mais confortável (notas do diário de campo). 
Após os três momentos realizados com cada membro da família, foi combinado o dia e horário em que Pâmela e Paulo me retornariam para construirmos o genograma. Após o término da coleta, acordamos sobre o envio dos TCLEs, finalizando assim nosso contato.

\subsubsection{Estudo de Caso 4: Família Pires}

Quem são os integrantes da família Pires? Uma breve apresentação e contextualização

Tabela 5

Caracterização da família Pires em termos de integrantes, estado civil, escolaridade ocupação/profissão, idade, religião e classificação socioeconômica

\begin{tabular}{|c|c|c|c|c|c|c|c|c|}
\hline Família & \multicolumn{2}{|c|}{ Integrantes } & $\begin{array}{l}\text { Tipo de } \\
\text { União }\end{array}$ & Escolaridade & $\begin{array}{l}\text { Profissão/ } \\
\text { Ocupacãa }\end{array}$ & $\begin{array}{r}\text { Idade } \\
\text { (anos) }\end{array}$ & Religião & $\begin{array}{c}\text { Classificaçãa } \\
\text { Socioeconômica }\end{array}$ \\
\hline \multirow{3}{*}{ Pires } & \multirow{2}{*}{ Pais } & Antônio & \multirow[b]{2}{*}{$\begin{array}{l}\text { União } \\
\text { Estável } \\
\quad(20 \\
\text { anos })\end{array}$} & $\begin{array}{l}\text { Ensino Médio } \\
\text { Completo }\end{array}$ & $\begin{array}{l}\text { Motorista } \\
\text { de Ônibus }\end{array}$ & 61 & Evangélica & \multirow{3}{*}{$\begin{array}{c}\mathrm{C} 1 \\
(\mathrm{R} \$ 2.800)\end{array}$} \\
\hline & & $\begin{array}{c}\text { E } \\
\text { Cristina }\end{array}$ & & $\begin{array}{c}\text { E } \\
\text { Ensino Médio } \\
\text { Completo }\end{array}$ & $\begin{array}{c}\text { E } \\
\text { Costureira }\end{array}$ & 55 & Evangélica & \\
\hline & Filha & $\begin{array}{l}\text { Ana } \\
\text { Julia }\end{array}$ & - & $\begin{array}{l}\text { Ensino Médio } \\
\text { (Cursando) }\end{array}$ & Estudante & 16 & Evangélica & \\
\hline
\end{tabular}

A Familia Pires é constituída por Antônio (pai), Cristina (mãe) e Ana Júlia (fillha do casal). Antônio, 61 anos, trabalha como motorista de ônibus em uma linha urbana. Cristina, 55 anos, trabalha como costureira em sua casa. Ana Julia, 16 anos, é estudante do ensino médio em uma escola pública e também faz alguns trabalhos de modelo de 
roupas para lojas locais. A familia Pires reside em casa própria, herdada por Cristina em sua cidade natal, localizada no interior de São Paulo.

Antônio e Cristina, se conheceram há pouco mais de 22 anos, quando Antônio mudou-se para a cidade natal de Cristina em busca de trabalho, e vivem em regime de união estável há 20 anos. Em relação a religião, a familia se autodenomina evangélica e destaca que frequenta o culto ao menos uma vez na semana.

Como também é possível observar a familia pertence ao nível socioeconômico $\mathrm{C} 1$ de acordo com o Critério de Classificação Econômica Brasil, o que os coloca entre os 22,2\% da população brasileira pertencente a esse nível econômico (ABEP, 2015). Destaca-se que a renda mensal familiar citada é de 2.800 reais mensais, que refere-se a renda de Antônio. A renda de Cristina não é contabilizada pela familia, pois ambos declaram que além de ser uma quantia muito variável, Cristina ficou algum tempo sem trabalhar devido ao tratamento de câncer que teve início há cinco anos aproximadamente.

A seguir será apresentado o Genograma da Familia Pires:

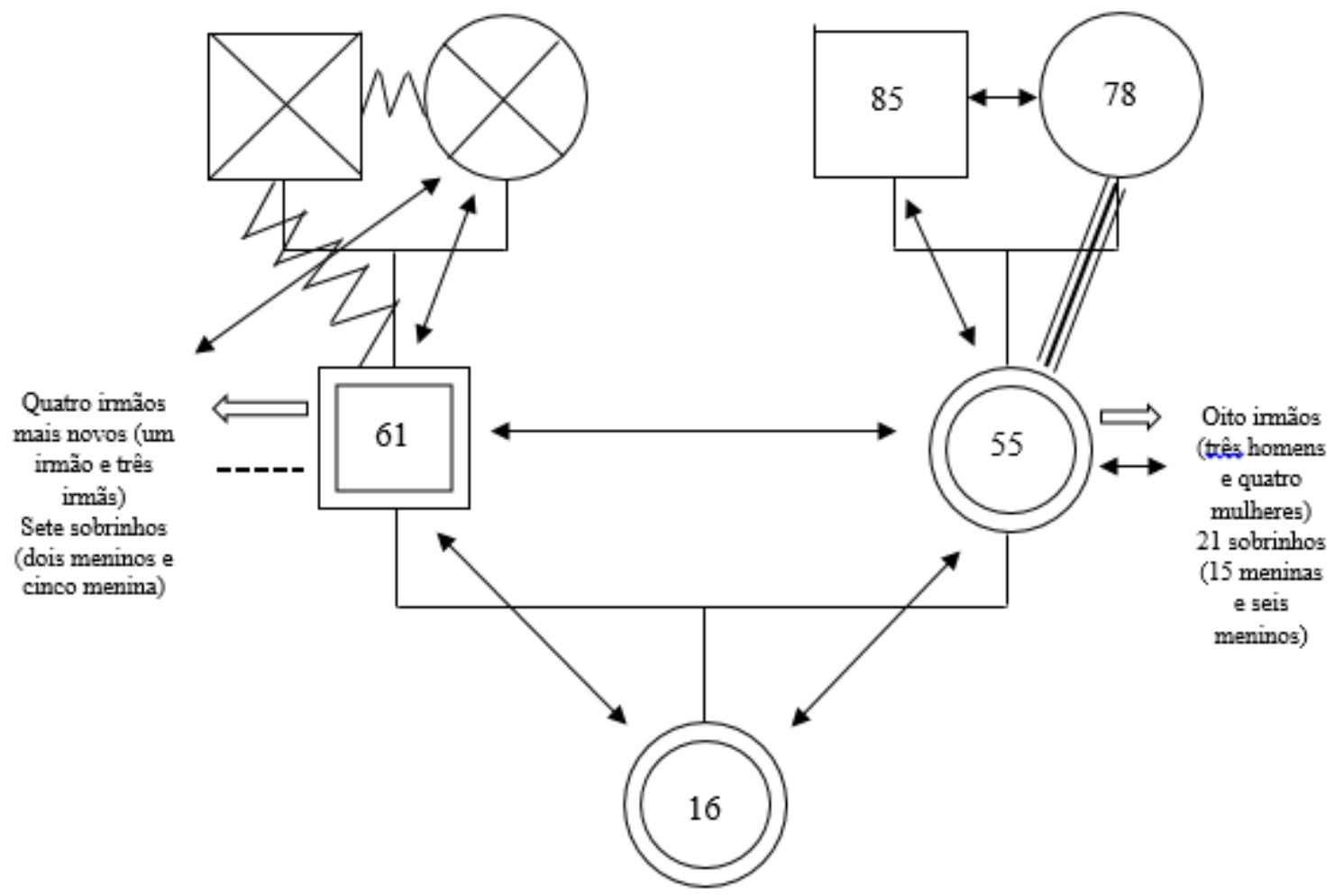

Figura 4. Genograma da Família Pires 
Antônio

Antônio, pardo, 61 anos, natural de uma pequena cidade do interior de Minas Gerais, é o filho mais velho de uma familia composta por pai (falecido), mãe (falecida) e cinco filhos, sendo dois homens e três mulheres. Em seu discurso, Antônio destaca que possui um relacionamento distante com seus irmãos e descreve vários fatores que considera que contribuíram pra isso:

Tivemos uma vida muito sofrida. Desde pequeno eu e eles já trabalhamos. Não tínhamos tempo pra conversar e também meu pai não deixava a gente brincar não. $\mathrm{Na}$ roça não tinha tempo pra isso, criança era igual adulto, trabalhava sabe. Depois cada um foi seguindo seu rumo. Cada um mudou atrás de trabalho ou porque casou. Depois que meus pais morreram aí que a gente não se viu mais quase (Antônio, 61 anos).

Ainda a este respeito, ele alega que sabe que atualmente com a tecnologia nenhuma distância impede que as pessoas se comuniquem e se encontrem, no entanto, revela que trata-se de um distanciamento natural, relacionado ao modo que eles foram criados "Não sei te explicar, mas a gente não foi criado assim não, apegado um com outro, parece que a gente não consegue falar que o irmão faz falta e que sente saudade. É o nosso jeito, entendeu?"

Quanto ao relacionamento com seu pai até o momento de seu falecimento, Antônio o definiu como conflituoso, caracterizando seu genitor como uma pessoa agressiva, rígida e exigente, relembrando as brigas dele com sua mãe e o modo como ele tratava os filhos:

Foi uma infância muito triste.... Meu pai sempre foi agressivo, batia na minha mãe, na gente. Não tinha essa de esposa e filho não, ele mandava e pronto sabe. Acho que ele também foi criado daquele jeito. Não tinha carinho, conversa, nada disso. A gente foi crescendo e não via a hora de ir embora. Eu não queria deixar minha mãe, mas ela falava que não tinha casado pra separar e que já estava acostumada. Não tenho lembrança boa dele não (Antônio, 61 anos). 
Em relação a mãe, Antônio relata que em meio a uma vida de brigas e medos, devido ao seu pai, ela sempre manteve seu jeito dócil e carinhoso, na tentativa de assegurar aos filhos que tudo ficaria bem. Destaca que independente do que estivesse acontecendo ela tentava acalmá-los e protege-los:

Minha mãe estava sempre ali, com aquele jeito dócil e carinhoso. Quantas vezes eu me perguntei como ela aguentava aquilo. Hoje vejo que naquela época as mulheres aceitavam muita coisa por conta dos filhos e porque foram criadas pra não separar. Ele estava sempre cuidando da casa e tentando acalmar a gente. Era só meu pai virar as costas que ela dava carinho, abraçava.... (Antônio, 61 anos).

Antônio destaca que, mesmo após sair de casa para trabalhar fora, sempre manteve um bom relacionamento com sua mãe e a visitava quando possível. Quando do falecimento de seu pai, ele chegou a morar novamente com ela, mas logo ela também faleceu e foi então que ele se mudou para uma pequena cidade do interior de São Paulo em busca de emprego e conheceu Cristina.

No que tange ao seu relacionamento com Cristina, Antônio o define como repleto da tranquilidade que ele sempre buscou. Destaca que sempre desejou casar e ter filhos, mas que as mudanças em busca de uma vida mais tranquila financeiramente foram adiando este plano:

Eu queria sim ter filhos sabe, mas financeiramente não dava e eu sempre estava indo de um lugar para o outro buscando emprego. A gente é parecido, ela nunca tinha casado antes, queria ter filhos, mas não tinha acontecido também. Aí namoramos, começamos a viver juntos, ela demorou para engravidar por conta da idade eu acho, mas aí veio a Ana. Nossa vida é simples, mas é tranquila. Tenho a tranquilidade que nunca tive, que minha mãe nunca teve (Antônio, 61 anos).

A respeito da paternidade e da relação com sua filha, Antônio destaca que busca ser um pai melhor a cada dia e possui uma relação muito harmoniosa com sua filha:

A gente se dá muito bem. A mãe dela até fala que eu sou o favorito (risos). Ela é uma menina linda. Agora nessa tal de adolescência você já viu né, mas eu tento 
ser pai e amigo ao mesmo tempo. Apoio ela quando acho que está certo e explico o que não acho certo. A gente conversa bastante.

Em seu discurso sobre a relação pai-filha, Antônio revela ainda sua tentativa, ao ser pai, de romper totalmente com o modelo recebido do seu genitor. Segundo ele, relembrar o pai que teve é doloroso, mas o ajuda a ser um pai melhor e a construir essa relação harmoniosa com sua filha.

\section{$\underline{\text { Cristina }}$}

Cristina, branca, 55 anos, trabalha como costureira em sua casa, é a segunda filha de uma família composta por pai, mãe e nove filhos, sendo cinco mulheres e três homens. A participante relata que possui um bom relacionamento com todos seus irmãos, destacando que, embora cada um esteja envolvido com sua familia, eles têm o hábito de se encontrarem nas datas festivas e também de se comunicar frequentemente pelo telefone.

A participante define a relação com seu pai como harmoniosa, o caracterizando como um homem sério, bravo, porém acolhedor "Quando a gente era pequeno, ele sempre foi sério e bravo sabe. Ainda é hoje. Mas não tenho o que reclamar, ele está sempre ali, para puxar orelha mas também para acolher."

Destaca ainda que, enquanto ao pai coube a função de ensinar o que é certo e errado, corrigindo e exigindo que os filhos seguissem suas ordens, à sua mãe coube o papel de cuidadora da casa e dos filhos. A respeito de sua relação com a sua mãe, Cristina a define como um relacionamento muito estreito, no qual ela atribui ao fato de ter sido a filha que morou mais tempo com seus pais a responsabilidade por ter tornado sua mãe dependente emocionalmente dela:

Minha mãe sentiu muito quando eu saí de casa. Acho que ela queria que eu tivesse minha família, mas também acho que na cabeça dela eu nunca sairia dali. Às vezes brinco que não sei se a mãe sou eu ou ela, porque ela depende muito de mim. 
$\underline{\text { Ana Julia }}$

Ana Julia, branca, 16 anos, é estudante do ensino médio em uma escola pública e também faz alguns trabalhos de modelo de roupas para lojas locais. Em relação ao seu dia-dia, Ana Julia relatou que além das atividades relacionadas à escola, ela costuma auxiliar seus pais nas tarefas domésticas e aos finais de semana sair com seus amigos. Destacou ainda seu trabalho como modelo de algumas lojas locais, relatando que, a renda proveniente do mesmo é investida em um curso de inglês e também na compra de itens pessoais, como roupas, sapatos, entre outros:

É normal, eu faço as tarefas escolares, ajudo os meus pais em casa e também saio com meus amigos de final de semana. Tem também as fotos que eu faço sabe, hoje eu consigo pagar meu inglês e também comprar minhas roupas, sapatos, arrumar meu cabelo, essas coisas sabe. Meu pai brinca que se eu souber cuidar eu faço muito com pouco, então eu vou comprando (Ana Júlia, 16 anos).

Em relação as atividades em família, em seu discurso, Ana Júlia destacou momento em que ela e seus pais estão juntos, caracterizando assim um funcionamento familiar marcado pela união e pela ajuda mútua:

Eu sou filha única né, então nossa familia é pequena e a gente tenta fazer tudo junto. Minha mãe gosta que a gente almoce juntos. Meu pai gosta de assistir jornal à noite, então todo mundo assiste junto. Eu gosto muito de ver filmes, aí eles assistem comigo. As coisas de casa também, a gente organiza juntos. Um vai ajudando o outro né.... Sempre foi assim, mas depois que minha mãe ficou doente, a gente se uniu ainda mais (Ana Júlia, 16 anos).

No que tange ao relacionamento afetivo com seus pais, Ana Júlia definiu ambos como sendo muito carinhosos e atenciosos. No entanto, destacou sua mãe como sendo mais rígida e brava, e seu pai como sendo mais paciente:

Os dois são muito carinhosos comigo, só que minha mãe é mais brava e rígida sabe, já meu pai é mais amigo, tem mais paciência. Ele conversa mais. Sei lá, ele expressa mais os sentimentos sabe.... Minha mãe fala que ele é meu preferidinho 
(risos), mas não é isso, amo os dois né, mas como dizem, eu sou mais apegada com ele (Ana Júlia, 16 anos).

Ainda que tenha destacado características específicas de seus pais, no que diz respeito ao cuidado recebido ao longo dos anos, Ana Júlia destacou uma não diferenciação de atividades realizadas apenas pela mãe ou pelo pai "eu não vejo uma divisão não... Acho que sempre foi assim, quem estava em casa era quem dava banho, fazia a comida, cuidava de mim. Hoje é assim e eu não me lembro de ter sido diferente"

\section{$\underline{\mathrm{O} \text { encontro entre a pesquisadora e a família Pires }}$}

A família Pires tem como membro Antônio, um dos pais que também já havia participado de minha pesquisa de iniciação cientifica. Deste modo, retomei meus arquivos e realizei contato telefônico com Antônio, explicando os objetivos da minha pesquisa e convidando sua família para participar.

Logo quando comecei a falar ao telefone, Antônio se recordou de mim e foi muito solícito, aceitando o convite de prontidão. Nesta mesma ligação, ele perguntou (quase que já respondendo por elas) à sua esposa e filha se elas aceitariam participar e já negociamos uma data para eu ir à casa da família (notas do diário de campo).

Diante do aceite, no dia combinado, viajei até a cidade onde a família reside, chegando por volta das 13 horas. Antes de iniciar a coleta de dados, Antônio me apresentou sua esposa e sua filha e ficamos por algum tempo (aproximadamente 30 minutos) na sala conversando.

Durante este momento que ficamos conversando, Antônio perguntou um pouco sobre mim (o término da faculdade, minhas atividades do momento) e também me contou as mudanças principais que acontecerem na sua familia nos últimos anos. Neste momento, ele retomou sobre tratamento câncer de sua esposa e sua recente "alta". Contou também sobre como sua filha já tinha se tornado uma moça e estava até "se achando" modelo e tirando algumas fotos. Foi um momento de bastante descontração. Eu me senti muito acolhida e à vontade na casa da família. 
Naquele momento fui costurando no meu pensamento aquilo que ouvira há quatro anos com as novas informações. Tecendo assim, à minha maneira, parte da história da família Pires.

Após essa conversa, de acordo com a ordem estabelecida pela família, iniciei a coleta, primeiramente com Ana Júlia, a filha do casal, em que expliquei-a de forma acessível minha pesquisa e realizei as perguntas do roteiro de entrevista. Em seguida, foi o momento de entrevistar Antônio e, após finalizar a entrevista com o mesmo, a família me convidou para tomar um café da tarde, antes de prosseguir a coleta com Cristina:

Quando Antônio me dirigiu até a cozinha, Ana Júlia e Cristina já estavam lá. Enquanto Cristina tirava do forno um bolo que havia acabado de assar, Ana Júlia organizava à mesa e, Antônio, logo que entrou, já foi se oferecendo para "passar" o café. Questionei o que eu podia fazer e a família pediu apenas para eu me sentar e esperar. Cristina me questionou se eu gostava de bolo de cenoura; Ana Júlia perguntou se eu tomava leite, e Antônio disse que faria um café novo para mim. Foi um momento muito agradável, em que eu pude ver a interação da família e participar de um momento que mesmo parecendo corriqueiro à primeira vista, em minha percepção, revela muito da intimidade da família (notas do diário de campo).

Após o café, realizei a entrevista com Cristina. Destaca-se que a que aplicação dos instrumentos, tanto com Antônio quanto com Cristina, seguiu a seguinte ordem: Formulários de Dados Sociodemográficos e Critério de Classificação Econômica Brasil e Roteiro de Entrevista Semiestruturado, aplicados individualmente, e genograma, construído com a participação de toda a família, após a entrevista com Cristina.

\subsection{Eixos temáticos}

6.2.1 Construindo uma família: Adaptações da conjugalidade às novas experiências de ser pai

Ao falar da parentalidade, os casais, para além de citar as mudanças práticas incitadas por esta vivência em termos de relacionamento conjugal, abordaram o modo 
como as expectativas em relação ao desempenho do papel paterno e materno contribuem para que eles (re)construam diariamente suas relações, refletindo, principalmente acerca de que pais gostariam que seus filhos tivessem como modelo.

Dentre as principais mudanças incitadas pela parentalidade, a necessidade de reestruturação da rotina, de modo a conseguir atender as demandas dos filhos, seguida, consequentemente, pela redução do tempo tanto para o cuidado pessoal quanto para os momentos a dois, foi destacada pelos casais das quatro famílias participantes:

Não dá pra falar que não muda né. É como se gente tivesse acomodado com o diaa-dia e de repente tudo muda. Não é uma mudança ruim. O que eu tô te falando é que você precisa tá preparado pra conciliar o trabalho com o que ela [filha] .... Agora eu e a Alice acho que perdemos um pouco a liberdade que tínhamos né e tivemos que aprender a encontrar espaço para nossos momentos de casal, o que não é facil (Pedro, 47 anos - Familia Campos).

Olha, a gente trabalha muito, então o dia-a-dia é um pouco corrido sabe. Temos os momentos a dois e temos os momentos com ela [risos], mas com ela é claro. Se a gente for pensar, tivemos que reorganizar nossa vida, somos mais pais do que marido e mulher com certeza, mas falo mais de menos tempo do que afeto e tudo mais (Alice, 39 anos - Família Campos).

Muda, né, porque acaba tanto ela, como eu, direcionado a atenção para o filho. Antes, como era eu e ela, todo tempo era pra estar junto ou cada um cuidando das suas coisas. Hoje não.... (Joel, 61 anos - Familia Sampaio)

A gente acaba ficando mais sobrecarregado, não tendo mais tempo um para o outro. Está sempre muito cansado. Acaba tendo menos tempo mesmo, junto e também pra se cuidar. Menos tranquilidade (Estela, 32 anos - Família Sampaio)

Essa necessidade de se reorganizar enquanto casal após a chegada do filho, relatada pelos casais, já foi observada em diversos estudos na literatura, dentre os quais pode-se destacar o estudo de Gonçalves et al. (2013), realizado com 38 pais primíparos, dos quais seis participantes explicitaram que a chegada do filho havia diminuído a liberdade e o tempo para a relação conjugal, já que as atenções se voltavam para o filho. 
Quanto à rotina, doze destes 38 pais especificaram a adaptação em horários das atividades em casa e no trabalho, além da diminuição da frequência de atividades de lazer como passeios, viagens e festas.

Ainda que tais alterações, na rotina e na vida conjugal, tivessem sido relatadas, por vezes, como um aspecto complicador na relação do casal, destaca-se que os participantes acrescentaram às suas falas que os momentos em familia e as interações com os filhos compensavam toda e qualquer alteração na rotina:

Muda. Muda tudo, né? Mas assim, algumas coisas para pior, outras coisas para melhor, mas no geral, eu acho que foi para melhor, eu acho que foi bacana, foi uma consolidação de uma vida familiar mesmo né. A gente diminuiu de passear, porque a gente era maluco, a gente pegava o carro, antes da Sarah, a gente ia pra tudo quanto é lugar que tinha e ficava só nos dois. Agora, temos uma família, algo diferente, mas que compensa qualquer coisa. (Paulo, 53 anos - Família Azevedo).

Sabe aquela coisa que não dá ora ter tudo? Então, um filho é assim. Muda sua relação, mas não significa que é pra pior entendeu, é diferente. Não dá pra comparar em termos de melhor ou pior. Nada paga ter ela, então o resto a gente ajeita né (Pedro, 47 anos - Família Campos).

Muda a questão do marido e da mulher, porque tem ela né. Mas agora também temos coisas que só o nascimento dela trouxe. Então são coisas diferentes. No começo não é fácil, mas depois você se acostuma e percebe que não tem melhor coisa que um filho (Antônio, 61 anos - Família Pires)

Além de apontar as mudanças na rotina, Pedro e Alice (Família Campos) e Antônio e Cristina (Familia Pires) revelaram que suas expectativas em relação a paternidade e a maternidade, mas especificamente ao modo de exercer essas funções, fizeram com que o desejo de viver em harmonia ficasse ainda mais forte em ambos. A este respeito, foi possível verificar que ambos começaram a refletir sobre o ambiente que gostariam que suas filhas crescessem, tanto em termos do olhar que estas teriam para o relacionamento destes, quanto dos pais que desejariam que elas tivessem: 
Aí veio a minha filha e mudou. Eu passei a ver ela assim [pausa] ela continuou sendo minha namorada, amiga, tenho uma baita consideração por ela, me sinto muito atraído por ela e aí passei a ver ela também como mãe da minha filha né. Nós passamos a ser mais parceiros depois que veio a Isabela. Acho que ela [Isabela] precisa sentir isso. Sentir um ambiente que ela possa contar com os dois, sem brigas. Me machucava muito ver a relação dos meus pais. Não sei mais achamos que é importante para o futuro dela (Pedro, 47 anos - Família Campos).

Então eu vi muitos conflitos da minha mãe e do meu pai dentro de casa assim e eu não quero isso pra minha filha. Eu acho que todo mundo tem defeito, tem qualidade e as relações todas tem problemas, seja de trabalho, de amigo, de filha, de mãe. Eu acho que perfeito nada vai ser. Nós nunca brigamos muitos, sempre nos respeitamos, mas hoje sinto que isso ficou ainda melhor sabe, conversamos muito sobre o que não queremos que ela passe. Isso é muito importante (Alice, 39 anos - Família Campos).

Acho que eu já falei que a relação muda né. O que eu acho que é precisa ser pra melhor. A gente tenta ser um exemplo de casal e de pais pra ela. Acho importante ela ter um bom exemplo, viver tranquila e querer isso pra ela (Cristina, 55 anos Familia Pires)

$\mathrm{Eu}$ quero que ela tenha orgulho de dizer que a gente não briga, que tem pais bons e que fazem tudo por ela. Não quero que ela viva um inferno. A gente cuida dela e não ela cuida da gente. Ela precisa ter uma cabeça tranquila pra crescer bem né (Antônio, 61 anos - Familia Pires)

Estudos como o de com Freitas et al. (2007), destacam que o curso da gravidez e o nascimento do filho podem contribuir para que alguns casais desejem conviver harmoniosamente. No entanto, destaca-se ainda que, ao pensar no ambiente que gostariam que suas filhas crescessem, nota-se que Pedro, Alice (Familia Campos) e Antônio (Familia Pires) parecem olhar para a relação conjugal de seus próprios pais e, a partir de então, reavaliar esta vivência em termos daquilo que consideram bom ou não para o desenvolvimento de sua filha, desvelando assim, seus próprios sofrimentos enquanto filhos que presenciaram o relacionamento conflituoso de seus pais e uma busca por não 
repetir tal vivência. Deste modo, a partir de suas vivências com seus próprios pais, buscam definir aquilo que seria uma boa família, tornando a conjugalidade um espaço para dotar a paternidade de novos sentidos.

A este respeito pode-se refletir ainda, assim como destaca, Kaës (1998), o quanto as representações entre as gerações têm a função de organizar a escolha de objeto dos parceiros, o que se relaciona ao tipo de família que se deseja fundar e a educação mais alinhada ao ideal familiar:

Eu sempre falo pra ela, eu sempre desejei ter ao meu lado uma mulher independente. Casei com a inteligência dela também sabia. Eu sei que estamos juntos porque vivemos bem e não porque ela depende de mim ou eu dependo dela. É essa família que eu quero. Uma família que vive bem (Pedro, 47 anos).

Acho que a famîlia é algo muito importante sabe. Eu mudei muito o que eu pensava depois de tudo que passei com meu pai. Não depende só do jeito que a gente trata ela [Isabela] depende do como ela vê a gente, de como estamos tentando construir nossa relação. Não é que não vamos errar, não é isso, mas acho que estamos tentando que ele não seja um pai como o meu e como o dele (Alice, 39 anos).

Para Féres-Carneiro, Ziviani e Magalhães (2007), desde o momento da concepção, o sujeito está marcado pelos ideais dos pais e pelos mitos familiares que se inscrevem e estruturam o desenvolvimento dos filhos desde as primeiras vinculações. A família tem assim um papel fundamental enquanto intermediária no processo de transmissão de valores e significados, enfatizando as possibilidades de transformação inerentes ao ato de transmitir, permitindo a construção da subjetivação. Desse modo, a conjugalidade dos filhos não só reedita o romance familiar dos pais e mães, como também propicia a elaboração das vivências infantis. O encontro com o parceiro gera a oportunidade de metabolização e de desenvolvimento dos cônjuges, entrelaçando passado e presente, dentro de um projeto que pressupõe uma perspectiva de futuro a dois.

Benghozi (2005) destaca em sua obra a possibilidade de transformação dos vínculos afetivos a partir do trabalho psíquico de remalhagem e desmalhagem. $\mathrm{O}$ continente grupal familiar seria uma malhagem de vínculos de filiação e de afiliação que poderiam se transformar e se reconfigurar constantemente, gerando novos arranjos e 
novos entrelaçamentos. A partir dessas ideias, pode-se considerar que a conjugalidade seja uma forma de remalhagem recíproca dos continentes familiares das familias de origem de cada cônjuge. Desse modo, a familia não corresponderia apenas às heranças transmitidas ao nascer, mas também aos processos de transformação da malha inicial, em que o continente grupal está sempre aberto a novas configurações, podendo se aliar a outros continentes grupais familiares.

No que diz respeito especificamente ao exercício paterno, observou-se, nos relatos dos casais, a importância da parceria destes na construção do modo como o homem exerce seu papel enquanto pai. Aqui destaca-se, não somente a compreensão dos participantes acerca de como cada um deve desempenhar seus papeis sociais, mas também o importante papel que a mulher desempenha, no sentido de contribuir para que o exercício paterno dos participantes seja marcado pela participação na vida dos filhos:

Eu delego viu (risos). Eu acho que ele precisa participar tanto quanto eu e se eu pegar tudo pra mim eu não vou ajudar ele em nada. Ele quer ser um bom pai ele fala, então eu ajudo nisso (Alice, 39 anos- Família Campos).

Mulher tem essa mania de pegar tudo pra ela né!? Mesmo que ele não faça eu reclamo, peço pra ele fazer, estimulo ela pedir pra ele fazer. Finjo que nem estou ali (risos). Já foi a época que só a mãe cuidava (Pâmela, 46 anos - Famîlia Azevedo)

Tenho uma amiga que fala assim: 'Nossa, mas ele faz tudo é. Ele faz direito? Duvido'. Eu acho assim, para com isso de que só a mãe sabe fazer. Isso é historinha. Ele faz do jeito dele e eu do meu. Os dois são pais né. O erro das mulheres é que elas querem que o home participe, reclamam, choram as pitangas, mas não deixam eles fazerem (Estela, 32 anos - Familia Sampaio).

Eu fui criada em uma época que só a mãe cuidava né. Ele não, ele sempre quis fazer. Eu deixo. Acho que ele é pai e tem os mesmos direitos né. Ele se esforça e eu valorizo tudo que ele faz (Cristina, 55 anos - Família Pires).

Como já sabido, ainda se observa a vinculação da maternidade a uma aura idealizada, diferenciada em relação à paternidade (Cúnico \& Arpini, 2013), em que são 
comuns discursos sobre a existência de um instinto materno, o qual tornaria a mulher naturalmente predisposta para os cuidados infantis. Deste modo, observa-se que, ao abrir mão do "monopólio da maternidade" (Borsa \& Nunes, 2011), as participantes desta pesquisa estão contribuindo para romper a crença de que apenas elas seriam aptas para os cuidados dos filhos, impedindo assim, que os próprios pais acreditem nesta dita maior importância materna e isso afete na interação e relação destes com seus filhos e filhas.

Compreende-se aqui também que este auxilio das esposas em relação ao exercício da função paterna, possibilita, novamente, espaço para a remalhagem dos vínculos estabelecidos nas primeiras relações, proporcionando que eles reflitam sobre o modo de paternidade e maternidade que receberam e construam seu modo de ser pai, pautado nos aspectos positivos da parceria do casal.

\subsubsection{Que pai eи sou e que pai eи quero ser?}

Esta categoria envolve os discursos dos membros das familias a respeito de como os pais exercem a paternidade e também as expectativas e desejos de cada integrante em relação ao exercício deste papel. Ao buscar se definir enquanto pai, Pedro (família Campos), Joel (família Sampaio) e Paulo (familia Azevedo), fizeram menção a uma autoavaliação a respeito do pai que são e do pai que eles desejam ser, ou seja, de suas próprias expectativas:

Olha, eu tento ser um pai presente sabe. Não tem assim uma divisão de tarefas, mas acaba que a Alice faz mais coisas com ela. Sai mais, brinca mais com ela. A gente conversa [ele e a filha], ela me agrada, eu pego na escola, ajudo na tarefa, mas [pausa] na verdade eu acho que menos do que eu gostaria, me sinto mais autoritário eu acho. Me pego querendo ensinar mais regras do que carinho. Acho ruim isso porque ninguém quer ficar do lado de alguém que só chama atenção. Não sei se você me entende? Acho que é difícil entender também né. Não é que não sou carinhoso, mas acho que eu gostaria de fazer mais vezes essas coisas (Pedro, 47 anos - Família Campos).

O que eu posso fazer eu faço. Todos falam que eu sou participativo e eu também me vejo assim. A única coisa é que as vezes eu sou rígido, assim dando... as vezes 
a gente até dei uns tapinhas nele. Então, eu sou rígido, acho que sou até muito e isso é uma coisa que eu não queria ser (Joel, 61 anos - Família Sampaio).

Eu queria participar mais da vida dela. Às vezes minha esposa fala que eu estou mais presente nos momentos de lazer e que no dia-a-dia eu participo pouco. Sou atencioso, carinhoso, abraço, falo que amo, mas acho que queria participar mais, tipo no médico, na escola, essas coisas (Paulo, 53 anos - Familia Azevedo)

Assim como observado nos três pais, Alice (familia Campos) e Pâmela (famîlia Azevedo) ao definir seus maridos enquanto pais dividem suas falas em duas perspectivas, o modo como eles exercem a paternidade e seus desejos em relação a alguns aspectos deste exercício:

Deixa eu pensar como eu defino ele como pai? Eu defino ele como pai, no sentido de que ele gosta muito dela, participa da vida dela, só que ele é um pai impaciente sabe. Sempre falo pra ele que ele precisa tentar brincar mais, acompanhar mais atividades dela. Sempre fizemos as coisas juntos, não é que ele não faça, é que eu acho que ela precisa de mais (Alice, 39 anos - Família Campos).

Olha, ele é super carinhoso e atencioso, bem diferente do pai que eu tive em termos de abraçar, beijar, essas coisas, mas falo pra ele que acaba que a mãe aqui acaba fazendo bem mais coisas com ela. Não estou reclamando, a verdade é que ela reclama, faz falta sabe (Pâmela, 46 anos - Família Azevedo).

De modo semelhantes ao de seus pais, Vitória (Familia Azevedo), Isabela (Família Campos) e André (Família Sampaio), em seus discursos, relataram o desejo de uma maior participação dos pais em suas atividades:

$\mathrm{Eu}$ queria que ele brincasse mais comigo. Ele grita as vezes também. Ele fala que tá cansado e minha mãe brinca mais, fica mais comigo (Isabela, 6 anos - Familia Campos). 
Ele até que faz as coisas comigo. Às vezes ele não tem muita paciência. Ele também não abraça e beija igual minha mãe. É meio grosso as vezes (Vitória, 12 anos - Família Azevedo)

Ele faz muita coisa com a gente, mas não gosto quando ele bate. Eu sei que as vezes a gente até que merece, mas ele às vezes é muito bravo. Minha mãe não bate não, mas ele de vez em quando grita sabe (André, 12 anos - Familia Sampaio

É possível observar, nos relatos acima, que as expectativas, tanto dos pais quanto das mães e dos filhos, em relação ao papel paterno envolvem aspectos relacionados à uma maior participação e expressão de afeto dos pais nas atividades de seus filhos. Tais expectativas apresentadas pelos casais parecem se referir a uma tentativa de afastamento de um modo tradicional de paternidade, caracterizado, dentre outros aspectos, pela ausência da participação do pai nos cuidados diários dos filhos e também pela ausência de expressão de afeto (Balancho, 2004; Gomes \& Resende 2004; Vieira \& Souza, 2010). No caso de Pedro (Família Campos) e Joel (Familia Sampaio), em seus relatos, ainda que eles percebam a necessidade de serem pais mais participativos no cotidiano da filha, os mesmos parecem não compreender os motivos que por vezes lhe fazem assumir um papel de autoridade:

Eu não acho que sou ruim. Eu faço de tudo, mas aí quando vejo já foi, já bati, já gritei. Coisas desse tipo. Parece que é mais forte que eu, sabe? Sempre falo pra mim mesmo que não vai ser mais assim, e aí, pronto, escapa (Joel, 61 anosFamilia Sampaio).

Então, ninguém gosta de alguém que só chama atenção, né. Acho que eu sou carinhoso com ela, ela sabe disso. Mas essa impaciência e essa mania de chamar atenção o tempo todo, de um jeito até grosso sabe, isso eu não consigo controlar (Pedro, 47 anos - Família Campos)

A este respeito, é importante refletir sobre o modo que paternidade tem sido concebida na contemporaneidade e também sobre alguns aspectos associados à masculinidade. Os estudos acerca da paternidade, chamam atenção para a inexistência de uma concepção linear de paternidade, assim, tal concepção envolve rupturas e 
continuidades com o modelo tradicional, o que faz com que, assim como observado no relato dos casais da Família Campos, Familia Sampaio e Familia Azevedo, características das duas formas de vivenciar a paternidade, tradicional e contemporânea, estejam presentes de maneira concomitante, tanto no mesmo tempo e no mesmo lugar por homens diferentes como em diferentes momentos e lugares pelo mesmo homem (Dantas, et al., 2004; Hegg, 2004; Gomes \& Resende, 2004; Thurler, 2006; Freitas et al., 2007; Perucchi \& Beirão, 2007; Thurler, 2006; Vieira \& Souza, 2010; Oliveira \& Silva, 2011).

Como já mencionado, ressalta-se ainda que, embora as transformações sociais repercutam na concepção de paternidade, subsistem ainda no imaginário social marcas da estrutura tradicional, uma vez que, a masculinidade sempre esteve social e historicamente associada à não demonstração de afeto, sensibilidade e cuidado. Assim, deve-se considerar ainda que, em meio a esta ressignificação de experiência e busca por uma maior aproximação afetiva dos filhos, existe a preocupação se essa nova postura pode ou não interferir na manutenção da masculinidade (Staudt \& Wagner, 2008), o que torna a disposição em reconhecer os sentimentos e confrontar certas determinações do papel de gênero masculino uma difícil tarefa.

Ao olhar para o modo que exercem a paternidade e expressarem seus desejos de uma maior participação na vida de seus filhos, Pedro (Família Campos) e Joel (Família Sampaio), relataram algumas lembranças de seus pais e da relação destes com os filhos, questionando-se, por vezes, se seriam parecidos com os mesmos, desvelando assim, o modelo recebido de paternagem como um possível impedimento de expressão de afeto e carinho pelas filhas:

Eu tento muito me aproximar mais dela sabe [pausa]. Não sei se tem a vê, mas eu acho que herdei um pouco o jeito do meu pai. Eu digo assim, por exemplo, meu pai trabalhou muito fora, ele era construtor e ia pra outros estados. Meu pai praticamente não viu a gente crescer, então ele tinha aquele jeitão ... a gente percebia o carinho dele, mas era seco né, não era de ficar bajulando né e eu também acho que eu sou um pouco assim [pausa] mesmo não querendo ser. Tá dando pra entender o que eu tô querendo dizer? Não tô te falando que ele ruim, ele ensinou muita coisa boa pra gente. Tornou a gente pessoas do bem, com valores, caráter, mas ele tinha aquele jeitão sabe, meio seco (Pedro, 47 anos - Familia Campos). 
Quando vejo já chamei atenção de uma forma que não acho legal ou bati. Sou muito rígido e sei disso. Tento desde meu primeiro filho não ser assim, a Estela me alerta, mas parece que algo mais forte, sei lá, minha geração, o pai que tive, você deve saber me explicar isso (Joel, 61 anos - Família Sampaio)

Alice (Família Campos), ao definir Pedro enquanto pai, também apresentou reflexões a respeito do quanto acredita que o modelo recebido do próprio genitor e a divisão de tarefas, em que à mulher atribui-se os cuidados dos filhos e ao homem a provisão financeira, podem contribuir no modo como cada pessoa exerce a paternidade e a maternidade:

Olha eu acho que entra uma criação aí, viu. Assim minha sogra fazia tudo, ele [Pedro] foi criado em um modelo em que a mulher fazia todo o cuidado dos filhos e o homem não. Meu sogro era aquele que trabalhava e colocava o dinheiro na casa. A gente tenta mudar isso sabe. Espero que a geração da Isabela mude ainda mais (Alice, 39 anos - Família Campos).

O modo como a relação vivida com o próprio pai contribui na compreensão do homem de sua masculinidade e de como ela o assume no exercício da paternidade tem sido discutida por diversos autores. De acordo com Freitas et al. (2007), ao tornar-se pai o homem buscará referências em seu próprio pai e ao encontrar, na maioria das vezes, o modelo de pai distante e pouco envolvido afetivamente, o filho incorpora esse modelo e reproduz, portanto, a relação pai-mãe-filho, tal como determinada socialmente e experimentada na sua vivência. Em contraposição, Gomes e Resende (2004), lembram que "o ser pai" atualiza no homem conflitos em relação ao seu próprio pai, de maneira que, ao sentirem seus pais como distantes, por exemplo, desejem se tornar pais diferentes. Gabriel e Dias (2011), por sua vez, destacam que o homem, ao se constituir como pai, (re)avalia a relação vivida com o próprio pai, mas não deixa de questionar essas concepções dadas a priori, tomando para si tanto o modelo tido de paternagem como o modelo de como um bom pai deve ser, no seu próprio imaginário e concebendo uma nova e singular maneira de ser pai.

Assim, a partir do relato de Pedro (Família Campos), Joel (Familia Sampaio) e Paulo (Familia Azevedo) é possível perceber o quanto eles tem tentado não repetir/reproduzir totalmente o modelo recebido, questionando-o de maneira a valorizar 
aspectos que considerados positivos, como ensinamento de valores, como humildade e honestidade, buscando exercer uma paternidade pautada no modo como acreditam que um bom pai deve ser, ou seja, mesclando aspectos considerados positivos da vivência com seus pais com aspectos que sentia falta nesta relação, como por exemplo, a expressão de afeto e a participação na vida de sua filha:

Bem diferente do que é hoje. Não tinha uma relação amistosa: pai era pai, filho era filho, sabe? Meu pai ele era um pai bastante novo né, então as vezes ele jogava bola, isso era bom, só que ele era um carro sisudo, ele não era um cara que abraçava, beijava. Ele ficava pouco em casa também, não participava muito (Paulo, 53 anos - Família Azevedo).

Meu pai muito trabalhador, toda vida apoiou a gente em tudo. Era rígido nas coisas, mas eu acho que ensinou o caminho certo para a gente. E a gente tentou aproveitar o melhor disso (Joel, 61 anos - Família Sampaio)

Meu pai tinha um jeito dele sabe, não era muito presente, trabalhava muito, era um construtor sabe, mas ele tinha os dois lados, tinha o jeito dele de ser carinhoso e eu que eu herdei muito dele sabe. Ele não era carinhoso de beijar e abraçar sabe, por exemplo, quem ensinou ele a beijar e abraçar fui eu, sabe? (Pedro, 47 anos Familia Campos)

Antônio (Familia Pires) ao se definir enquanto pai também também refere a importância do modelo recebido na construção de uma paternidade marcada pelo afeto e participação, no entanto, de modo diferente dos três, este refere-se a uma busca constante de se afastar totalmente da vivência tida com seu pai, refutando tal modelo:

Ele não me deixou nada de bom. Nenhuma lembrança boa. Falar que teve coisa boa. Não sei, acho que até esqueci, se teve foi uma gota que se perdeu no mar de sofrimento. Então me acho completamente diferente dele e não aceitaria ser igual em nada nada (Antônio, 61 anos - Família Pires). 
No caso de Pedro, Paulo e Joel, faz-se importante pensar ainda quanto a relação e a concepção de paternidade das mães tem contribuído para que eles (re)avaliem a relação tida com seus próprios pais e construam seu modo de ser e querer ser pai:

Acho assim que a gente tem uma tendência a repetir alguns erros e eu tento ajudar ele nisso sabe. Eu gosto que o Pedro participe em tudo sabe porque isso faz falta no futuro, então eu delego as coisas pra ele sabe. Acho que as vezes as mulheres pegam tudo pra elas e eles vão deixando né. Então eu aprendi a delegar, falo pra ele trocar, ajudar na tarefa, sair sozinhos e tal. E ele faz (Alice, 39 anos - Família Campos).

Eu falo pra ele sabe. Olha Paulo, precisa participar mais, não existe isso de que a mãe é a melhor pra cuidar não. Eu acho que preciso estimular sabe, as vezes até mando ele fazer mesmo, pra ver se assim ele percebe que dá conta tanto quanto eu (Pâmela, 46 anos - Família Azevedo).

O lugar ocupado pela mãe na transição e exercício da parentalidade como um aspecto que influencia o exercício da paternidade tem sido ressaltado na literatura. A este respeito, como já destacado, historicamente, o afeto e o cuidado foi tratado como um atributo materno (Cúnico \& Arpini, 2013), em que vinculou-se a maternidade a uma aura idealizada e a paternidade relacionada a responsabilidades sociais de provisão, o que pode trazer prejuízos no campo da subjetividade (Freitas et al., 2007). Assim, destaca-se, nas falas de Alice (Famillia Campos) e Pâmela (Familia Sampaio), a compreensão em relação à importância de que elas atuem como facilitadoras na relação de seus esposos e filhos, buscando, desse modo, romper com um modelo baseado em um divisão de tarefas, em que elas assumiriam o papel de cuidadoras e eles o sustento financeiro da casa, o que contribui não só com sua desvinculação delas com o papel de cuidadora de maior importância como também auxilia os pais a expressarem seus afetos pelas filhas.

Pode-se destacar ainda que, a compreensão de Alice (Família Campos) parece refletir, assim como observado em Pedro, uma busca de romper com os aspectos negativos do modelo recebido de paternidade e maternidade, possibilitando assim que sua filha vivencie, na relação com ela e Pedro, o modelo que ela acredita ser um bom pai e uma boa mãe: 
Meu pai sempre foi uma pessoa distante sabe. Minha mãe era quem cuidava da gente, tanto é que ela só foi trabalhar depois da separação. Eu não quero isso pra Isabela, eu não quero que ela tenha as lembranças que eu tenho do meu pai. Hoje acho que com a Sofia ele é melhor, talvez pela idade também né. Ele foi um pai jovem sabia? (Alice, 39 anos).

A esse respeito, na perspectiva da psicanálise dos vínculos sociais de Benghozi (2010) compreende-se que os vínculos estabelecidos entre pais e filhos no início da vida podem ser remalhados ou desmalhados em função dos vínculos estabelecidos na vida adulta. Desse modo, como é possível observar nas falas elucidadas dos membros das

quatro familias, as vivências dos homens com seus próprios pais e, no caso da Família Campos, Família Azevedo e Família Sampaio, a relação deles com suas esposas parecem revelar-se como elementos para a reconfiguração de seus vínculos iniciais assimilados como falhas, devido ao sofrimento psíquico da relação com seus pais na infância. Assim, tem-se um espaço de ressignificação do impedimento sentido em relação a expressão de afeto e maior participação na vida dos filhos, devido a relação com seus pais.

\subsubsection{Potencialidades e dificuldades da paternidade na meia-idade}

Ao falar sobre a vivência da paternidade na meia-idade, alguns participantes, principalmente pais e mães, citaram características que eles descrevem como pertencentes a esta fase do ciclo vital e que, em suas percepções, permeiam o exercício da paternidade, dotando-o de potencialidades e desafios/dificuldades. A maturidade emocional foi destacada por todos os pais e mães da pesquisa como uma característica consolidada, na percepção destes, ao longo da meia-idade, sendo considerada uma potencialidade do exercício paterno nesta fase:

Talvez lá atrás eu não tivesse maturidade e acho que me cobraria por isso. Não sei se dizer isso é importante, mas eu acho que com o passar do tempo a gente quer muito a estabilidade e a gente amadurece em muitas coisas né.... Por exemplo, hoje eu sou feliz com minha familia... e eu acho que sou feliz porque hoje a familia é o que mais faz sentido pra mim, as coisas de antes não fazem sentido mais, eu amadureci e acho que isso é uma vantagem (Pedro, 47 anos - Familia Campos). 
Os pais mais velhos acho que tem mais maturidade sabe. Os jovens acho que talvez sejam imaturos pra assumir tamanha responsabilidade. Não que não possa fazer, não é isso, mas acho que ele é mais maduro (Alice, 39 anos - Família Campos).

$\mathrm{Eu}$ acho que eu tenho muito mais conhecimento do que uma pessoa de 18, então ela vai fazer mais cagadas com um filho. Desculpa o jeito de falar mais é isso que eu penso. Uma pessoa de 40 anos é tranquila, mais sossegada, tem mais tempo pra pensar, tratar, cuidar. Uma pessoa de 18 anos, ela ainda está querendo dominar o mundo, querendo sair, agitar e tal, então ele não quer criança, neném. (Paulo, 53 anos - Familia Azevedo).

Talvez maturidade e responsabilidade sabe. Bom eu acho que muito do que sou como mãe é devido a minha maturidade e acho que ele também. Infelizmente sinto que de maneira geral os pais já não são tão apegados aos filhos e acho que a idade dele ajuda para que esta questão seja melhor (Pâmela, 46 anos - Família Azevedo).

Eu acho que sim, porque você está mais maduro, você sabe mais o que quer. Então acho que isso ajudou bastante.... Você estar mais hábil para lidar com as coisas e não estar tão afoito a sair, aventuras. Então o fato de você não ter essa, né, que quando você é muito jovem você quer mais é badalação, festa, não sei o que. Quando você está mais velho, isso diminui. Seus objetivos são outros. E uma coisa que foi boa é isso, você se volta para a família (Joel, 61 anos - Família Sampaio)

A maturidade acho que é o meu forte (risos). A gente precisa se valorizar né, então acho que ser pai na minha idade é melhor neste sentido, porque sou mais maduro e acho que isso ajuda nas minhas decisões (Antônio, 61 anos - Família Pires).

A estabilidade financeira foi destacada, por três casais (Familia Campos, Família Azevedo e Familia Sampaio), como uma condição adquirida ao longo do tempo, representando assim uma potencialidade do tornar-se pais na meia-idade: 
Acho que eu tenho uma relação diferente com o dinheiro, nessa idade [mais jovem] eu acho que eu não teria, eu era um sonhador, eu achava que como todo moleque ter coisas assim era o mais importante. Talvez eu não teria a vida tão definida e estabilizada como hoje. Isso é uma coisa que me incomoda. Eu não ia querer que ela passasse por problema financeiro, por exemplo, a gente faz tudo que pode pra ela, inglês, ballet. Acho que é isso que eu vou deixar pra ela. Formação sabe. (Pedro, 47 anos - Familia Campos).

Acho que a estabilidade financeira também ajuda, acho que hoje em dia a gente tá vivendo um mundo cada vez mais competitivo, cada vez mais maluco e acho que se você estiver um pouco mais estabilizado você consegue oferecer coisas para o seu filho que talvez se você tenha um filho com 20 anos você não consiga (Alice, 39 anos - Familia Campos).

$\mathrm{Eu}$ não teria o dinheiro que eu tive, eu não teria a experiência que eu tive, eu não teria o emprego que eu tinha, eu não teria a estrutura que eu tive, ou seja, meu filho teria uma vida de cão (Paulo, 53 anos - Família Azevedo).

Tem uma vida estruturada, um plano de vida. Uma estabilidade, não quer mais sair, ir pra boate. A questão financeira. Primeiro que dando as aulas a gente vê. Pais mais jovens eu acho imaturos. Eu indicaria ser pais mais velhos, mas claro que exceções (Pâmela, 46 anos - Familia Azevedo)

A questão de dinheiro também. Eu sei que tem famílias que se sustentam com um salário mínimo, mas acho que o passar do tempo foi um dos responsáveis por eu ter uma estabilidade financeira que ajuda na criação dos meus filhos. Claro que tem outros fatores, mas a idade está relacionada eu acho (Joel, 61 anos- Familia Sampaio)

É possível observar que ao falar da maturidade e da estabilidade financeira os participantes apresentaram em seus discursos a percepção de que alguns aspectos e características vão se transformando ao longo do ciclo vital, tomando, como exemplo, como se sentiam quando mais jovens e o que acreditam que um pai mais jovem vivencia em relação à questão financeira e a (i)maturidade. A meia-idade, ou vida adulta 
intermediária, é caracterizada por ser uma fase em que geralmente as pessoas já se encontram profissionalmente estáveis e tendem a limitar ativamente os seus contatos sociais, aumentando a proximidade emocional e atribuindo maior importância às relações significativas (Kovács, 2010). Essa afirmação corrobora pelos achados do presente estudo, na medida em que os participantes percebem a estabilidade financeira, a maturidade e o desejo de se dedicar à família como aspectos potencializadores da vivência da paternidade na meia-idade.

Ainda que a percepção dos participantes aponte para uma possível interpretação de que homens jovens seriam imaturos para desempenhar o papel paterno, destaca-se que os discursos de ambos pareciam querer revelar que a vivência da paternidade em diferentes fases do ciclo vital envolveria facilidades e dificuldades, não nomeando assim as vivências enquanto momentos estritamente positivas ou negativas, a depender da idade. A este respeito, Levandowski e Piccinini (2002) ressaltam que enquanto alguns estudos evidenciam que a interação do pai adolescente com o bebê ficaria prejudicada pelas limitações desenvolvimentais do próprio pai, outros estudos demonstram que os adolescentes são capazes de superar essas adversidades. Estudos realizados por Trindade e Menandro (2002) e Sampaio, Villela e Oliveira (2014) revelaram que dentre os aspectos apontados pelos jovens de maior impacto após a paternidade está à perda de liberdade, sentimentos de inadequação ao papel paterno, por se considerarem imaturos e inexperientes, e dificuldades em relação a questão financeira.

Assim ao passo que, os participantes consideram que a maturidade e a estabilidade financeira adquiridas ao longo da vida podem ser considerados facilitadores da paternidade na meia-idade, ambos também apresentaram aspectos significados no dia-adia como dificuldades de tal vivência, atribuindo-os à idade. Dentre estes aspectos, membros das quatro famílias participantes destacaram a indisposição física, como uma dificuldade/desafio do exercício paterno nesta fase do ciclo vital:

Digamos que eu tô velho sabe [risos]. Tipo eu estaria mais pra avó do que pra pai. Me sinto pai, mas acho que daria mais pra avô [pausa].... Então na hora que a Isabela quer brincar, isso aquilo, eu acho que eu não tenho paciência. $\mathrm{Na}$ verdade, sempre fui impaciente sabe, acho que é mais disposição mesmo. Parece que não [risos], mas acho que a idade tá batendo, viu. Não é aquela coisa de não aguentar a fazer as coisas, é um cansaço que não sentia antes, uma indisposição, acho que mental até, e ela [pausa] é elétrica né. (Pedro, 47 anos - Família Campos). 
Então, eu acho que tem diferença pros dois lados de ser pais mais velho, para o bom e para o ruim. Eu acho que os pais mais jovens têm mais disposição e paciência pra brincar mesmo e isso que acho que o Pedro não tem [risos]. É claro que em mim eu já percebo que é difícil aguentar o pique dela, mas pra ele eu percebo que isso está sendo difícil, o cansaço mesmo, a indisposição física (Alice, 39 anos - Familia Campos).

Nossa, a disposição física eu acho. Estes dias o André me falou que o pai de alguém jogava bola com ele. Eu pensei, aí filho isso o pai tá velho. Tenho amigos também que já estão aproveitando a vida sem os filhos em casa porque eles estão na faculdade e eu estou perdendo o fôlego correndo atrás do meu (risos) que sobe na janela (Joel, 61 anos - Família Sampaio).

Nossa, não aguento assistir filme com ela e ela brinca que é porque sou velhinho (risos). Quando ela era criança eu as vezes pensava que estava mais pra avó do que pra pai porque não tinha pique para aquilo (Antônio, 61 anos - Família Pires).

Ao relatar a indisposição física como uma característica pertencente à meia-idade, significada como um desafio/dificuldade no exercício paterno, os participantes apresentaram comparações com pais mais jovens, alegando que, neste aspecto, estes teriam uma vantagem, não atribuindo apenas um sentido negativo a esta vivência e, portanto, dotando as vivências paternas em diferentes fases do ciclo vital com potencialidades e desafios:

Não sei, parece engraçado, não parece? Acho que é o que eu falei, tem a maturidade, experiência de vida, e a estabilidade financeira que não teria quando jovem, mas pelo contrário, a indisposição não se encaixa com uma filha que quer brincar toda hora (Alice, 39 anos - Família Campos).

Bom, por outro lado, seria uma relação assim, com mais disposição eu acho que da minha parte, acho que eu ia ter mais pique né. Eu pratico esportes, procuro uma disposição física, mas acho que até mental mesmo que eu quero dizer (Paulo, 53 anos - Família Azevedo). 
Ele brinca que eu não aguento fazer mais coisas por conta da idade. Acho que isso é uma vantagem de pais mais jovens, a disposição. Os meninos questionam o porquê no jogo ele é sempre juiz. Ele não fala, pisca e diz que é porque se ele jogar ele ganha (risos) mas não aguenta correr muito mais não (Estela, 32 anos Familia Sampaio)

Eu queria jogar bola com meu pai, mas eu acho que ele tá meio velho pra isso. Ele cansa rápido. Eu participo de um time de futebol e lá alguns pais treinam com os filhos. O meu pai tem problema no coração também. Acho que ele não joga por isso. É normal se eu me sentir mal com isso? (André, 12 anos - Familia Sampaio)

A redução da energia física, cansaço, fadiga e diminuição da força e falta de condicionamento físico são vistas como perdas que se iniciam na meia-idade (Antunes \& Silva, 2013). Desse modo, em seus discursos os participantes referem-se a percepções de mudanças corporais reais, que parecem vir à tona na relação com os filhos e nas demandas apresentadas por esta, o que também foi observado no estudo de Colleti e Scorsolini-Comin (2015).

A esse respeito, pode-se refletir ainda que, os estudos acerca dos casais de meiaidade, com ênfase na parentalidade, identificam essa fase como um momento de saída dos filhos de casa e de entrada de novos membros (noras e/ou genros e netos) no sistema familiar, focando assim na necessidade de o casal reestruturar sua relação conjugal após a saída dos filhos (Jorge, 2005; Ribeiro, 2005), movimento inverso, como já destacado, ao vivenciado pelos homens que se tornaram pais na meia-idade.

Para além das demandas de suas filhas, a percepção das alterações físicas parece ter levado Pedro (47 anos - Família Campos) e Paulo (53 anos - Família Azevedo) a buscarem praticar atividades físicas que, mesmo sendo apresentadas como prazerosas, parecem ser tentativas de não se deixar abater por tais alterações, desafiando-as, revelando uma possível ambiguidade:

Meu ponto de equilibrio de dois anos para cá, quando a idade começou a bater e vieram as dores no joelho, decorrentes também da época que joguei futebol, tem sido o esporte. Eu ando 45 quilômetros por dia de bicicleta, toda manhã. Durante o esporte eu penso muitas coisas. Eu me sinto renovado sabe. O ciclismo me faz 
bem e eu não parei mais até hoje. Eu não entendia o que as pessoas queriam dizer, mas você adquire um equilibrio muito grande em todos os sentidos da vida. É incrível, um simples andar de bicicleta. Lá eu penso na minha vida, nos meus problemas, e consigo encontrar soluções (Pedro, 47 anos - Família Campos).

Hoje eu busco a saúde e aumentar minha capacidade física e cognitiva. O que é ser velho? O que é ser um pai velho? Posso ter 60 anos e sair aí com minha moto, caminhar quilômetros por dia. Isso é que eu busco, então minha vida recentemente, depois que eu percebi que estava envelhecendo, é comer bem e caminhar, pra melhorar minha capacidade física e cognitiva né (Paulo, 53 anos Familia Azevedo)

Como já destacado, a meia-idade, também denominada por Erik Erikson com maturidade, caracteriza-se por um momento que envolve um processo de mudança de um período mais produtivo para outro de elaboração das experiências vividas, podendo provocar sentimentos de ambivalência, uma vez que a pessoa sente sua vitalidade ao mesmo tempo em que percebe alterações físicas e psíquicas do processo de envelhecimento (Trindade, 2002). Assim, tanto Pedro (47 anos - Família Campos) quanto Paulo (53 anos - Familia Azevedo) parecem ter encontrado nas atividades físicas a possibilidade de melhorar a disposição física e, no caso de Paulo, a capacidade cognitiva, mas também um modo de reafirmar a vitalidade diante das alterações físicas sentidas e do envelhecimento.

Destaca-se aqui, a ambivalência desta fase do ciclo vital, ao perceber que, mesmo apresentando potencialidades da meia-idade, ambos, Pedro (47 anos - Família Campos) e Paulo (53 anos - Familia Azevedo), no que diz respeito aos aspectos corporais, parecem realizar atividades físicas intensas na busca de retardar o envelhecimento do corpo, o que parece uma dificuldade em lidar com este.

Reflete-se aqui também, de que indisposição física ambos estão falando quando referem-se à interação com seus filhos, uma vez que, estes se apresentam como homens capazes de andar/caminhar quilômetros por dia. Deste modo, Pedro (47 anos - Familia Campos) e Paulo (53 anos - Família Azevedo) parecem realizar uma distinção daquilo que seria disposição para interagir com os filhos e disposição para as atividades físicas, em que, para a primeira estes se consideram cansados, enquanto que, para a segunda, estes se consideram aptos. As atividades físicas intensas seriam um modo de negar para si 
o envelhecimento? A indisposição física para interagir com os filhos está relacionada apenas com a idade, como eles atribuem, ou diz respeito a uma dificuldade de interação pai-filha? A interação com os filhos se faz presente no modo como estes homens exercem a paternidade?

Ainda a respeito da interação diária com os filhos, Pedro e Alice (Familia Campos) e Joel e Estela (Familia Sampaio) relataram que um pai mais jovem teria mais facilidade na interação pai e filho no âmbito de brincadeiras e atividades:

Enquanto relação eu acredito que seria bem mais legal, acho que eu seria mais mulecão e conseguiria entrar mais no mundo dela nas brincadeiras, porém [pausa] não sei, talvez eu seria imaturo. Aí eu acho que pode ser problema da idade também. Eu acho que isso me [pausa] não, não acho que prejudica, quer dizer, eu acho que eu tinha que entrar mais no mundo dela pra brincar e eu acho que eu não consigo [pausa], eu acho que é um pouco culpa minha, que sou sem paciência, e um pouco por conta da idade, parece que eu tô muito longe dela, assim, em relação à idade e às brincadeiras (Pedro, 47 anos - Família Campos).

Acho que ele teria mais disposição. Às vezes, acho que ele não entende muito as brincadeiras dela, que não consegue voltar para o mundo de uma criança. Eu acho que seria bom nesse sentido de brincar de disposição, mas acho que seria ruim na imaturidade, na questão financeira (Alice, 39 anos - Família Campos).

Mas tenho que te falar também né, parece que ser pai mais jovem é horrível e que eu falo tanto isso. Mas o que dá inveja deles é a disposição né. Já pensou meus filhos me vendo jogando bola? Acho que um pai mais jovem além da disposição, consegue entender e entrar mais no mundo deles (Joel, 61 anos - Família Sampaio).

Foi possível observar nestes relatos que além da indisposição física, os participantes apresentam a diferença de idade entre pai e filho como um aspecto que dificulta a "entrada" no "mundo" dos filhos. Ainda que não associe diretamente a indisposição do pai à sua idade, é possível perceber nas falas de Isabela (6 anos - Família Campos) o desejo de que o pai brincasse mais com ela: 
Tem [atividades que gostaria que o pai fizesse]. Ele brinca pouco. Ele gosta bastante de andar de bicicleta, mas eu não ando. Às vezes, ele pula corda e joga futebol. Brinco sozinha e com a minha mãe. Tenho um quarto cheio de brinquedo sabia!? Ganho de aniversário e dia das crianças (Isabela, 6 anos - Familia Campos).

André (12 anos - Família Sampaio) e Vitória (12 anos - Família Azevedo), diferente de Isabela (6 anos - Família Campos), associam, em suas falas, a não participação de seus pais em algumas atividades à idade destes, destacando tanto a indisposição física quanto a dificuldade deles em compreender as brincadeiras atuais:

Já te falei sobre o futebol? Acho que ele não joga porque não aguenta correr, sei lá. Tem outras coisas também que ele não faz. Eu e meu irmão, a gente joga videogame e ele fala que na época dele não tinha essas coisas. Aí ele não sabe, não joga (André, 12 anos - Família Sampaio)

Ele implica comigo, fala que eu não brinco e que só fico em celular. Minha mãe fala que é porque quando eles eram pequenos não tinha isso né. Acho que é por isso que ele implica tanto, ele não tinha isso, quando ele tinha minha idade tinha outras coisas e ele não entende. Aí ele fala que só fico no quarto, eu fico (risos), mas ele não entende nada do que eu gosto (Vitória, 12 anos - Família Azevedo)

Destaca-se ainda que, em contraposição à estas dificuldades, os casais buscam em suas falas valorizar a maturidade e estabilidade financeira, dotando, novamente, a paternidade na meia-idade e, de modo implícito, a paternidade nas diferentes fases do ciclo vital, de sentidos múltiplos que envolve potencialidades e dificuldades. Essa valorização dos aspectos considerados positivos na vivência paterna na meia-idade também foi observada no estudo de Colleti e Scorsolini-Comin (2015), cujos pais entrevistados elucidaram em suas falas estratégias para compensar, por exemplo, a falta de disposição física.

Explorando ainda a questão financeira, a proximidade da aposentadoria revelouse, para Pedro (47 anos - Família Campos) como uma preocupação, sendo significada como algo que ameaçaria sua estabilidade financeira e, consequentemente, o futuro de sua filha: 
Porque assim, pra mim que sou autônomo, é claro que a estabilidade (financeira) veio conforme a idade, mas se eu for parar pra pensar, na hora que eu deveria estar pensando em aposentar ou diminuir o ritmo de trabalho, vai ser a hora em que minha filha, se tudo correr bem, vai tá indo pra faculdade e tudo mais. Vai ser a hora que vai precisar de mais dinheiro (pausa). Vai ser a hora que eu não vou poder parar de trabalhar. Que não vou poder me deixar vencer pelo cansaço. E aí!? [emociona-se]. Aí acho que a idade vai pesar (Pedro, 47 anos - Família Campos).

Em estudo realizado por Silva e Silva (2014) com 14 pais, cuja faixa etária variou entre 15 e 61 anos, sendo cinco com idade ente 46 a 61 anos, as autoras verificaram que a iminência da aposentadoria representou uma ameaça à estabilidade da família, em especial, à satisfação das necessidades dos filhos, o que é consistente com os achados do presente estudo. A esse respeito, pode-se refletir ainda que, de modo implícito, a preocupação de Pedro (47 anos - Família Campos) pode revelar também um receio de envelhecer e ficar improdutivo, inválido ou impotente, o que, segundo Trindade (2002), pode revelar-se fortemente nessa fase, estando relacionado ao modo como a constituição subjetiva do homem ocorreu e ainda ocorre - vinculada à produção, à capacidade de controle do corpo e das pessoas e aos valores enaltecidos em nossa cultura de sobrevalorização da juventude, aliada à desvalorização do envelhecimento.

Considerando a questão financeira, ainda que Pedro e Alice (Família Campos) sejam responsáveis pelo sustento da casa, o discurso de Pedro, em relação a aposentadoria, remete a uma concepção da paternidade em que o homem continua sendo o responsável pelo sustento da casa e pela provisão do sustento do filho, o que reafirma, conforme destacado por Gomes e Resende (2004), que embora as transformações sociais repercutam na concepção de paternidade, subsistem ainda no imaginário social marcas da estrutura tradicional. Nesse sentido, assim como apontado na literatura, a vivência de paternidade ora se ancoraria no modelo de pai tradicional, ora aponta a perspectiva de um novo modelo de ser pai: o "novo pai", que visita o pai tradicional, mas afasta-se dele, dotando a paternidade de sentido mais amplo, (Freitas, Coelho, \& Silva, 2007).

Já para Joel (61 anos - Família Sampaio), a proximidade da aposentadoria foi retratada como uma possibilidade de dispor de mais tempo para cuidar dos filhos: 
Você já pensou que estou quase pra me aposentar? Louco né, um velhão com um filho pequeno. Mas um velho que vai ter todo tempo do mundo pra eles. Não vejo a hora de me aposentar. Tenho muitos planos. Vai ser bom, a Estela ainda tem muito chão, mas eu vou aproveitar pra ficar mais com eles [filhos]. Fazer mais do que eu faço. Pai em tempo integral. Já pensou, vou ficar de cabelos mais brancos ainda (risos), vai ser muito divertido (Joel, 61 anos- Familia Sampaio).

Ainda a respeito dos desafios/dificuldades, o medo de não poder acompanhar o desenvolvimento dos filhos foi destacado por Pedro (47 anos - Família Campos), Joel (61 anos - Família Sampaio) e Antônio (61 anos - Família Pires) como uma desvantagem de ter se tornado pai na meia-idade, sendo significado como um pensamento que por vezes vem à tona e os assombra:

Eu não vou te mentir não, tem uma coisa que não falo muito, mas as vezes eu penso em uma coisa que me dá medo [pausa]. Eu queria ver a Isabela chegar na minha idade sabe. Na verdade, queria ver meus netos também, sabe, eu gostaria, mas não sei se vai dar tempo. Será que dá tempo? Bom, acho que a Isabela, se ela seguir o que eu falo, ela vai depois de tá formada e independente, ela vai procurar um namorado firme, com uns 25 anos, aí eu vou tá com [pausa], com quantos anos? Acho que vai... Bom, se eu continuar do jeito que eu levo minha vida, praticando esportes... [risos] (Pedro, 47 anos - Família Campos)

Olha, preciso viver mais uns bons anos. Não tenho medo da morte não, mas tenho medo em deixar eles. Não vou ver netos eu acho né. Isso já me conformei. Agora, olha para o mais novo, aí bate um medo. Eu preciso preparar eles e a Estela pra isso. Sei que muita gente vai me falar que pra morrer basta estar vivo e não tem idade, mas [pausa] tem a ordem natural das coisas também né (Joel, 61 anos Familia Sampaio).

Ela é filha única, então, se a gente morrer, ela fica meio sozinha. Sei que vou morrer, viu, mas acho que penso mais nisso pela minha idade, pela idade em que fui pai, não, não, acho que mais por ter tido pais novinhos (Antônio, 61 anos Familia Pires) 
No que tange aos filhos, ainda que não tenha surgido nenhuma fala que tratasse especificamente do medo da morte dos pais, Vitória (12 anos - Família Azevedo), Ana Júlia, (16 anos - Famîlia Pires), André (12 anos - Família Sampaio), ao falarem sobre como eles imaginam que seus pais estariam daqui a 10 anos, relataram o desejo de que eles estejam vivos:

Não sei, trabalhando ainda, provavelmente. Com saúde. E vivo. Talvez com mais dificuldade para fazer algumas coisas, tipo, um pouco de dificuldade para andar, ou qualquer coisa assim (André, 12 anos - Família Sampaio)

Vivo, né! Com o cabelo mais branco eu acho (risos) (Vitória, 12 anos - Família Azevedo)

Às vezes ele fala assim, eu quando eu morrer, você não faz isso, hein. Então, se eu pudesse desejar algo pra ele, acho que é que ele viva uns 120 anos. Será que tem alguém que já viveu isso? Acho que ouvi dizer que tem (Ana Júlia, 16 anos Familia Pires).

Em relação às falas dos pais, para além de uma compreensão ensinada pela biologia, em que na sequência natural dos fatos os mais velhos morrem primeiro (Alarcão, Carvalho, \& Pelloso, 2008; Bittencourt, Quintana, \& Velho, 2011), destacam-se as contribuições de Kovács (2010), em que se considera que o adulto pode passar por crises, como a chamada "crise da meia-idade", caracterizada por um período em que vai se conscientizando de que é inevitável morrer, à medida que reconhece novas limitações físicas e vivencia importantes mudanças nos principais papéis desempenhados até então.

Assim, para os três pais, a conscientização de sua finitude parece ser significada como algo ainda mais doloroso, ao entrelaçar-se com suas reflexões acerca da sua idade e do horizonte de desenvolvimento de sua filha. Nesse sentido, destaca-se, no caso de Pedro, que em nenhum momento de sua fala ele nomeou essa "coisa" de morte, o que parece reafirmar sua dificuldade de lidar com a finitude. Nesse ponto, volta-se a refletir sobre o ciclismo como uma possível tentativa de desafiar as alterações físicas e psíquicas do processo de envelhecimento.

De modo geral, pode-se destacar, a partir dos relatos, que as características e mudanças ocorridas ao longo da vida e nesta fase do ciclo vital em especial, sejam elas 
tomadas como potencialidade ou dificuldades/barreiras, parecem vir à tona não só com suas percepções do próprio corpo e de seus sentimentos, mas também no exercício da função paterna e nas demandas apresentadas pelos filhos (Colleti \& Scorsolini-Comin, 2015). 


\section{CONSIDERAÇÕES FINAIS}

O presente estudo teve como objetivo geral compreender a experiência da paternidade na meia-idade a partir da perspectiva de pais, mães e filhos envolvidos no contexto de famílias intactas, buscando conhecer as principais motivações ou explicações para essa vivência e as possíveis potencialidades e dificuldades da paternidade nessa fase do ciclo vital, a partir dos relatos dos próprios pais, suas esposas e filhos.

No que tange especificamente a vivência paterna na meia-idade, acredita-se que, com este trabalho, seja possível destacar algumas de suas especificidades, dentre as quais destaca-se a maturidade e a estabilidade financeira como uma potencialidade desta vivência, enquanto que a indisposição física e o receio em não presenciar o desenvolvimento dos filhos revelaram-se como um desafio/dificuldade do tornar-se pai na meia-idade. Deste modo, foi possível observar que algumas percepções e mudanças reais em relação à essa fase do ciclo vital foram dotadas de novos sentidos ao atrelar-se com as demandas da paternidade, não á nas perspectivas dos pais, quanto na das mães e filhos.

Destaca-se ainda que, além destas especificidades, a compreensão da paternidade na meia-idade envolve a consideração de vários aspectos que se articulam e se entrelaçam. A inexistência de uma concepção linear de paternidade, decorrentes das mudanças sociais ocorridas nas últimas décadas, bem como a referência que os pais têm de seu próprio genitor revelaram-se nos discursos dos integrantes das famílias como aspectos que contribuem no exercício do papel paterno e nas expectativas em relação ao mesmo. Assim, observou-se que ao (re)avaliar o desempenho de seu próprio pai, os pais do presente estudo tem buscado, com auxilio de suas esposas e filhos, romper com os aspectos negativos dessa experiência e exercer uma paternidade participativa, baseada na proximidade afetiva, o que na perspectiva psicanalítica de Benghozi (2010) possibilita a remalhagem dos Vínculos.

As adaptação da conjugalidade às novas experiências do ser pai e a importância do papel das mães na construção do exercício paterno desejado também apresentou-se como possibilidade de remalhagem dos vínculos estabelecidos em suas nas primeiras relações, revelando assim, o exercício de um papel paterno pautado na parceria do casal e nos aspectos positivos desse relacionamento amoroso, uma vez que, juntos, o casal tem buscado construir um relacionamento harmonioso para criação dos seus filhos.

Compreende-se a limitação do estudo em termos de números de participantes apresentados. Destaca-se ainda as dificuldades encontradas no recrutamento de famílias 
que se enquadrassem a todos os critérios de seleção preestabelecidos. No entanto, considerando a grande importância de se investigar os diversos envolvidos na transição para a parentalidade e a escassez de estudos que tratem a vivência paterna na meia-idade, espera-se que este estudo possa despertar o interesse por novas investigações acerca da temática a partir do relato dos seus próprios protagonistas, possibilitando assim espaços de debates que possam corroborar, enriquecer e ampliar os resultados apresentados neste estudo. 


\section{REFERÊNCIAS}

Alves-Mazzotti, A. J. (2006). Usos e abusos dos estudos de caso. Cadernos de Pesquisa, 36(129), 637-651.

Antunes, P. C., \& Silva, A. M. (2013). Elementos sobre a concepção da meia-idade no processo de envelhecimento humano. Revista Kairós Gerontologia, 16(5), 123-140.

Arroyo, M.G. (2004). Significados culturais dos tempos da vida. In: quebradas: trajetórias e tempos de alunos e mestres. Petrópolis (RJ): Vozes.

Imagens

Balancho, L. S. F. (2004). Ser pai: Transformações intergeracionais na paternidade. Análise Psicológica, 2(22), 377-386.

Bandeira, M., Goetz, E. R., Vieira, M. L., \& Pontes, F. A. R. (2005). O cuidado parental e o papel do pai no contexto familiar. In F. A. R. Pontes, W. L. B. Magalhães, R. C. S. Brito, \& W. L. B. Martin (Orgs.), Temas Pertinentes à Construção da Psicologia Contemporânea (191-230). Belém-Pará: UFPA

Bartholomew, K., Henderson, A.J.Z. \& Márcia, J.E. (2000). Coding semistructured interviews in social psychology research. Em H.T. Reis \& C.M. Judd (orgs.), Handbook of research methods in social and personality psychology (pp.286-312). UK: Cambridge University Press.

Becker, H. S. (1994). Métodos de pesquisa em ciências sociais (2a ed). São Paulo: HUCITEC.

Belo, J., \& Macedo, M. (1996). Ascensão e queda do poder do Pai: O novo pai emergente. In Actas do $1 .^{\circ}$ Colóquio de Psicologia Social Clínica (pp. 89-99). Lisboa: ISPA.

Benghozi, P. (2005). Resiliência familiar e conjugal numa perspectiva psicanalítica dos laços. Psicologia Clínica, 17(2), 101-109.

Benghozi, P. (2010). Malhagem, filiação e afiliação - Psicanálise dos vínculos: Casal família, grupo, instituição e campo social. (E. D. Galery, Trad.). São Paulo: Vetor.

Berttran, D. E., Gomes, I. C. (2013). A vincularidade enquanto malha e seu esgarçamento ante o luto. Pensando Famílias, 17(1), 77-88.

Bogdan, R. C., \& Biklen, S. K. (1997). Investigação qualitativa em educação: Uma introdução à teoria e aos métodos. Portugal: Porto Editora.

Bornholdt, E. A., Wagner, A., \& Staudt, A. C. P. (2007). A vivência da gravidez do primeiro filho à luz da perspectiva paterna. Psicologia Clínica, 19(1), 75-92.

Borsa, J. C., \& Nunes, M. L. T. (2011). Aspectos psicossociais da parentalidade: O papel de homens e mulheres na família nuclear. Psicologia Argumento, 29(64), 31-39. 
Carter, B., \& McGoldrick, M. (2001). As mudanças no ciclo de vida familiar: Uma estrutura para a terapia familiar ( $2^{\mathrm{a} E d}$.). Porto Alegre: Artmed.

Cecîlio, M. S., \& Scorsolini-Comin, F. (2013). Relações entre conjugalidade e parentalidades adotiva e biológica. Psico (Porto Alegre), 44(2), 245-256.

Chizzotti A. (2006). Pesquisa qualitativa em ciências humanas e sociais. Petrópolis: Vozes.

Colleti, M., \& Scorsolini-Comin, F. (2015). Pais de primeira viagem: A experiência da paternidade na meia-idade. Psico (Porto Alegre), 46(3), 374-385.

Costa, N. R. A., \& Rossetti-Ferreira, M. C. (2009a). Acolhimento familiar: Uma alternativa de proteção para crianças e adolescentes. Psicologia: Reflexão e Crítica, 22(1), 111-118.

Costa, N. R. A., \& Rossetti-Ferreira, M. C. (2009b). Become mother and father in late adoption: A case study. Child and Family Social Work, 14, 58-67.

Crepaldi, M. A., Andreani, G., Hammes, P. S., Ristof, C. D., \& Abreu, S. R. (2006). A participação do pai nos cuidados da criança, segundo a concepção de mães. Psicologia em Estudo, 11(3), 579-587.

Cruz, O. (2005). Parentalidade. Coimbra, Portugal: Quarteto.

Cúnico, S. D., \& Arpini, D. M. (2013). A família em mudanças: Desafios para a paternidade contemporânea. Pensando Família, 17(1), 28-40.

Dantas, C., Jablonski, B., \& Féres-Carneiro, T. (2004). Paternidade: Considerações sobre a relação pais filhos após separação conjugal. Paidéia, 14(29), 347-357.

Denzin, N. K., \& Lincoln, Y. S. (1994). Handbook of qualitative research. Thousand Oaks: SAGE.

Duarte, L. F. D. (2009). Família, moralidade e religião: Tensões contrastivas contemporâneas em busca de um modelo. In G. Velho, \& L. F. D. Duarte (Orgs.), Gerações, família e sexualidade (pp. 17-45). Rio de Janeiro: 7Letras.

Eiguer, A. (1985). Um divã para a família (L. M. V. Fisher, Trad.). Porto Alegre: Artes Médicas.

Eiguer, A. (1995). O parentesco fantasmático: Transferência e contratransferência em terapia familial psicanalític. (M. A. Chiarella, Trad.). São Paulo: Casa do Psicólogo.

Eiguer, A. (1998). A parte maldita da herança. In A. Eiguer (Org.), A transmissão do psiquismo entre gerações (pp. 21-84). São Paulo: Unimarco.

Erikson, E. H. (1976a). As oito idades do homem. Rio de Janeiro: Zahar.

Erikson, E. H. (1976b). Identidade: juventude e crise. Rio de Janeiro: Zahar. 
Féres-Carneiro, T., Magalhães, A. S., \& Ziviani, C. (2006). Conyugalidad de los padres y proyectos de vida de los hijos frente al matrimonio. Revista Cultura y Educación, 18(1), 95-108.

Ferreira, M. E. M. (2008). A meia-idade e a alta modernidade. Construção Psicopedagógica, 16(13), 77-91

Flick, U. (2002). Entrevista episódica. Em M.W., Bauer \& G. Gaskell. (orgs.), Pesquisa qualitativa com texto, imagem e som. Um manual prático (pp. 114-126). Petrópolis: Vozes.

Fontana, A., \& Frey, J. H. (2005). The interview: From neutral stance to political involvement In. N. K. Denzin \& Y. S. Lincoln (Edit.), The handbook of qualitative research ( $3^{\mathrm{a}}$ ed.), (p.695-728). Thousand Oaks: SAGE.

Fraser, M. T. D., Gondin, S. M. G. (2004). Da fala do outro ao texto negociado: discussões sobre a entrevista na pesquisa qualitativa. Paidéia, 14(28), 139-152.

Freitas, W. M. F., et al. (2009). Paternidade: Homem no papel social de provedor. Revista de Saúde Pública, 43(1), 85-90.

Freitas, W. M. F, Coelho, E. A. C., \& Silva, A. T. M. C. (2007). Sentir-se pai: A vivência masculina sob o olhar de gênero. Cadernos de Saúde Pública, 23(1), 137-45.

Gabriel, M. R., \& Dias, A. C. (2011). Percepções sobre a paternidade: descrevendo a si mesmo e o próprio pai como pai. Estudos de Psicologia, 16(3), 253-261.

Gil, A. C. (1991) Como elaborar projetos de pesquisa. São Paulo: Atlas.

Gomes, A. J. S., \& Resende, V. R. (2004). O pai presente: O desvelar da paternidade em uma família contemporânea. Psicologia: Teoria e Pesquisa, 20(20), 119-125.

Gomes, I. C., \& Zanetti, S. A. S. (2009). Transmissão psíquica transgeracional e construção de subjetividade : relato de psicoterapia psicanalítica vincular. Psicologia USP, 20(1), 93-108.

Gottman, J., \& DeClaire, J. (1997). Los mejores padres: Como desarrollar la inteligencia emocional de sus hiros. Argentina: Javier Vergara Editor.

Hennigen, I. (2010). Especialistas advertem: O pai é importante para o desenvolvimento infantil. Fractal: Revista de Psicologia, 22(1), 169-184.

Houzel, D. (2004). As implicações da parentalidade. In L. Solis-Pontom, L. (Org.), Ser pai, ser mãe. Parentalidade: Um desafio para o terceiro milênio (pp. 47-51). São Paulo: Casa do Psicólogo.

Hurstel. F. (1999). As novas fronteiras da paternidade. Campinas: Papirus.

Jablonski, B. (2010). A divisão de tarefas domésticas entre homens e mulheres no cotidiano do casamento. Psicologia Ciência e Profissão, 30(2), 262-275. 
Jager, M. E., \& Bottoli, C. (2011). Paternidade: Vivência do primeiro filho e mudanças familiares. Psicologia: Teoria e prática, 13(1), 141-153.

Jorge, M.M. (2005). Perdas e ganhos no envelhecimento da mulher. Psicologia em Revista, 11(17), 47-61.

Jovchelovitch, S \& Bauer, M.W. (2002). Entrevista narrativa. Em M.W. Bauer \& G. Gaskell (orgs.), Pesquisa qualitativa com texto, imagem, e som. Um manual prático (pp.90-113). Petrópolis: Vozes.

Julien, P. (2000). Abandonarás teu pai e tua mãe. Rio de Janeiro: Cia. De Freud.

Kaës, R. (1993). Le groupe et le sujet du groupe: Eléments pour une théorie psychanalytique du groupe. Paris: Dunod.

Kaës, R. (1998). Os dispositivos psicanalíticos e as incidências da geração. In A. Eiguer (Org.), A transmissão do psiquismo entre gerações (pp. 5-19). São Paulo: Unimarco.

Kaës, R. (2001). Transmissão da vida psíquica entre gerações. São Paulo: Casa do Psicólogo.

Kaës, R. (2005). Os espaços psíquicos comuns e partilhados: Transmissão e negatividade (I. Machado, \& P. C. G. Castanho, Trads.). São Paulo: Casa do Psicólogo.

Kovács, M. J. (2010). Morte e desenvolvimento humano (5a ed.). São Paulo: Casa do Psicólogo.

Lamb, M. E. (Org.). (1997). The role of the father in child development. New York: John Wiley \& Sons.

Lamb, M. E. (2000). Fathering. In Encyclopedia of Psychology (Vol. 3, pp. 338-341). Oxford: American Psychological Association.

Lamb, M. E., Pleck, J. H., Charnov, E. L., \& Levine, J. A. (1987). A biosocial perspective on paternal behavior and involvement. In J. B. Lancaster, J. Altaman, A. Rossi, \& R. L. Sherrod (Eds.). Parenting across the lifespan: Biosocial perspectives (pp. 11-42). New York: Academic.

Leão, M. A. B. G., \& Gíglio, J. S. (2002). Psicodinâmica da mulher trabalhadora de meiaidade em fase de pré-aposentadoria. Psico-USF, 7(2), 185-194.

Levandowski, D. C. (2001). Paternidade na adolescência: Breve revisão da literatura internacional. Estudos de Psicologia (Natal), 6(2),195-209.

Levandowski, D. C. \& Piccinini, C. A. (2004). Paternidade na adolescência: Aspectos teóricos e empíricos. Revista Brasileira de Crescimento e Desenvolvimento Humano, 14(1), 51-67.

Lewis, C., \& Dessen, M. A. (1999). O pai no contexto familiar. Psicologia: Teoria e Pesquisa, 15(1), 9-16. 
Lins de Barros, M. M. (2009). Três gerações femininas em famílias de camadas médias. In $\mathrm{G}$.

Lisboa, A. V., \& Féres-Carneiro, T. (2005). Quando o adoecimento assombra o grupo familiar. Pulsional: Revista de Psicanálise, 18(184), 40-48.

Magalhães, A. S., \& Féres-Carneiro, T. (2004). Transmissão psíquico-geracional na contemporaneidade. Psicologia em Revista, 10(16), 243-255.

Marchetti-Mercer, M. C., \& Cleaver, G. (2000). Genograms and family sculpting: An aid to cross-cultural understanding in the training of psychology students in South Africa. The Counseling Psychologist, 28(1), 61-80.

Meincke, S. M. K. \& Carraro T. E. (2009). Vivência da paternidade na adolescência: sentimentos expressos pela familia do pai adolescente. Texto Contexto Enfermagem, 18(1), 83-91.

Minayo, M. C. S. (1994). Pesquisa social: Teoria, método e criatividade. Rio de Janeiro: Vozes.

Monteiro, L., Verissimo, M., Santos, A. J., \& Vaughn, B. E. (2008). Envolvimento paterno e organização dos comportamentos de base segura das crianças em familias portuguesas. Análise Psicológica, 26(3), 395-409.

Moraes, M. L. Q. (2001). A estrutura contemporânea da familia. In M. C. M. Comparato \& D. S. F. Monteiro (Orgs.), A criança na contemporaneidade e a psicanálise Volume Família e sociedade: Diálogos interdisciplinares (pp. 17-25). São Paulo: Casa do Psicólogo.

Muzio, A. P. (1998). Paternidade (ser pai)... Pra que serve? In: Silveira, P. (Org). Exercício da paternidade (pp. 165-174). Porto Alegre: Artes Médicas.

Nogueira., H. F., \& Ribeiro, M. A. (2013). Os "Pais-avôs": A Dinâmoca familiar de homens que se tornaram pais na meia-idade. In A. Garcia \& R. Díaz-Loving (Orgs.). Relações familiares: Estudos latino-americanos. Vitória: UFES.

Oliveira, A. G., \& Silva. R. R. (2011). Pai contemporâneo: Diálogos entre pesquisadores brasileiros no período de 1998 a 2008. Psicologia Argumento, 29(66), 353-360.

Oliveira, M. K. (2004). Ciclos de vida: algumas questões sobre a psicologia do adulto. Educação e Pesquisa, 30(2), 211-229.

Organização Mundial da Saúde (2005). Envelhecimento ativo: uma política de saúde. Brasîlia: Organização Pan-Americana da Saúde.

Ortega, A. C. (1981). O Desenho da Familia como técnica objetiva de investigação psicológica. Arquivo Brasileiro de Psicologia, 33(3), 73-81. 
Perucchi, J., \& Beirão, A. M. (2007). Novos arranjos familiares: Paternidade, parentalidade e relações de gênero sob o olhar de mulheres chefes de família. Psicologia Clínica, 19(2), 57-69.

Pimenta, M., Veríssimo, M., Monteiro, L., \& Costa, I. P. (2010). O envolvimento paterno de crianças a frequentar o jardim-de-infância. Análise Psicológica, 28(4), 565-580.

Pleck, J. H., \& Pleck, E. H. (1997). Fatherhood ideals in the United States: Historical dimensions. In M. E. Lamb (Org.), The role of the father in child development (pp. 3348). New York: John Wiley \& Sons.

Ribeiro, M. T. M. L. S. R. (2005). Casais de meia-idade: Estudos com casais portugueses numa perspectiva sistêmica. Psicologia, 19(1-2), 57-85.

Romanelli, G. (2003). Paternidade em familias de camadas médias. Estudos e Pesquisas em Psicologia, 2(2), 79-96.

Rossetti-Ferreira, M. C., \& Costa, N. R. A. (2012). Construcción de vínculos afectivos en contextos adversos de desarrollo: Importancia y polemicas. Scripta Nova (Barcelona), 26(325), 98-13.

Roudinesco, E. (2003). A família em desordem. Rio de Janeiro: Jorge Zahar.

Shwalb, D. W., \& Shwalb, B. J. (2014). Fatherhood in Brazil, Bangladesh, Russia, Japan, and Australia. Online Readings in Psychology and Culture, 6(3). Recuperado de http://dx.doi.org/10.9707/2307-0919.1125

Silva, B. T., \& Silva, M. R. S. (2014). Necessidades e preocupações dos pais em diferentes etapas do ciclo vital. Revista Brasileira de Enfermagem 67(5), 957-964.

Souza, C. L. C., Benetti, S. P. C. (2009). Paternidade contemporânea: levantamento da produção acadêmica no período de 2000 a 2007. Paidéia, 19(42), 97-106.

Sousa, A. M. (2010). Síndrome de Alienação Parental: um novo tema nos juízos de família. São Paulo: Cortez.

Stake, R. E. (2005). Qualitative case studies. In. N. K. Denzin \& Y. S. Lincoln (Edit.) The handbook of qualitative research ( $3^{\mathrm{a}}$ Ed.), (p.443-466). Thousand Oaks: SAGE.

Staudt, A.C.P., \& Wagner, A. (2008). Paternidade em tempos de mudança. Psicologia: Teoria e Prática, 10(1), 174-185.

Tarnowski, K. S., Próspero, E. N. S., \& Elsen, I. (2005). A participação paterna no processo de humanização do nascimento: Uma questão a ser repensada. Texto \& Contexto Enfermagem, 14(spe), 102-108.

Thurler, A. L. (2006). Outros horizontes para a paternidade brasileira no século XXI? Sociedade e Estado, 21(3), 681-707. 
Trindade, E. (2002). Hermenêutica do existir do homem de meia-idade - Paternidade, sexualidade e projetos de vida: Um olhar à luz de Heidegger. Tese de Doutorado não-publicada, Faculdade de Filosofia, Ciências e Letras de Ribeirão Preto, Universidade de São Paulo, Ribeirão Preto, SP.

Turato, E. R. (2000). Introdução à Metodologia da Pesquisa Clínico-Qualitativa: Definição e Principais Características. Revista Portuguesa de Psicossomática, 2(1), 93-108.

Turato, E. R. (2005). Métodos qualitativos e quantitativos na área da saúde: Definições, diferenças e seus objetos de pesquisa. Revista de Saúde Pública, 39(3), 507-514.

Velho, G. (2009). Sujeito, subjetividade e projeto. In G. Velho, \& L. F. D. Duarte (Orgs.), Gerações, família e sexualidade (pp. 9-16). Rio de Janeiro: 7Letras.

Ventura, M. M. (2007). O estudo de caso como modalidade de pesquisa. Revista da SOCERJ, 20(5), 383-386

Vieira, E. N., \& Souza, L. (2010). Guarda paterna e representações sociais de paternidade e maternidade. Análise Psicológica, 4(28), 581-596.

Vieira, G. T. \& Nascimento, A. R. A. (2014). Aspectos psicossociais da construção da identidade paterna. Psicologia: Teoria e Prática, 16(1), 57-68.

Zambrano, E. (2006). Parentalidades "impensáveis": Pais/mães homossexuais, travestis e transexuais. Horizonte Antropológico, 26(12), 123-147.

Zanetti, S. A. S., \& Gomes, I. C. (2012). Efeitos da herança psíquica na opção pela não construção do vínculo amoroso. Estudos Interdisciplinares em Psicologia, 3(1), 57-74.

Zornig, S. M. A. (2010). Tornar-se pai, tornar-se mãe: O processo de construção da parentalidade. Tempo Psicanalítico, 42(2), 453-470.

Yin, R. K. (2001). Estudo de caso: Planejamento e métodos. Porto Alegre: Bookman.

Wagner, A., \& Bandeira, D. R. (1996). O desenho da família: Um estudo sobre adolescentes de família originais e reconstituídas, Trabalho apresentado no VI Simpósio de Pesquisa e Intercâmbio Cientifico da ANPEPP.

Wendt, N. C., \& Crepaldi, M. A. (2008). A utilização do genograma como instrumento de coleta de dados na pesquisa qualitativa. Psicologia: Reflexão e Crítica, 21(2), 302-310. 
ANEXO 1 - Legendas dos Genogramas, segundo Wendt e Crepaldi (2008)

(Baseado em em McGoldrick \& Gerson, 1995; Minuchin, 1982)

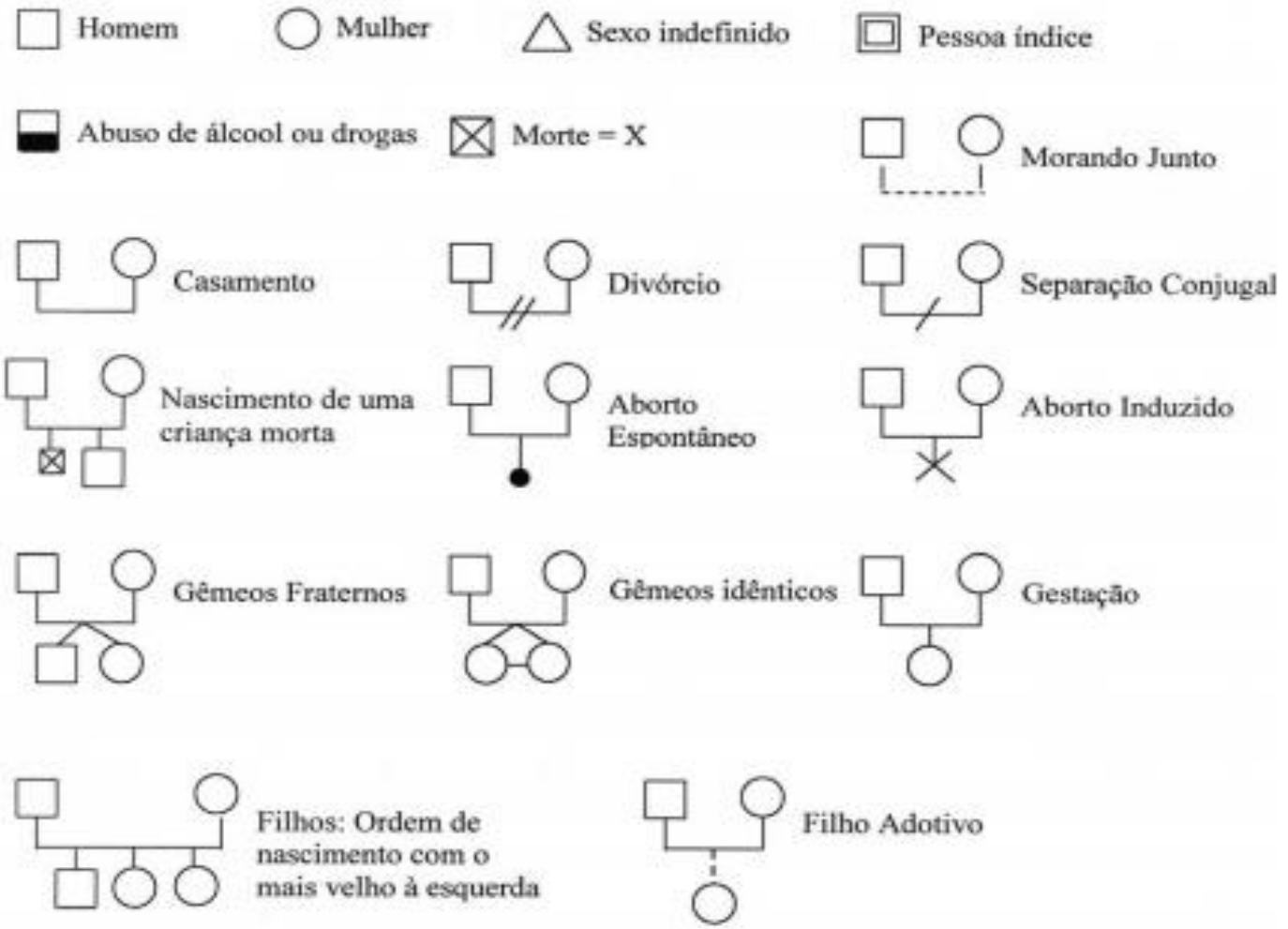

Relacionamentos:

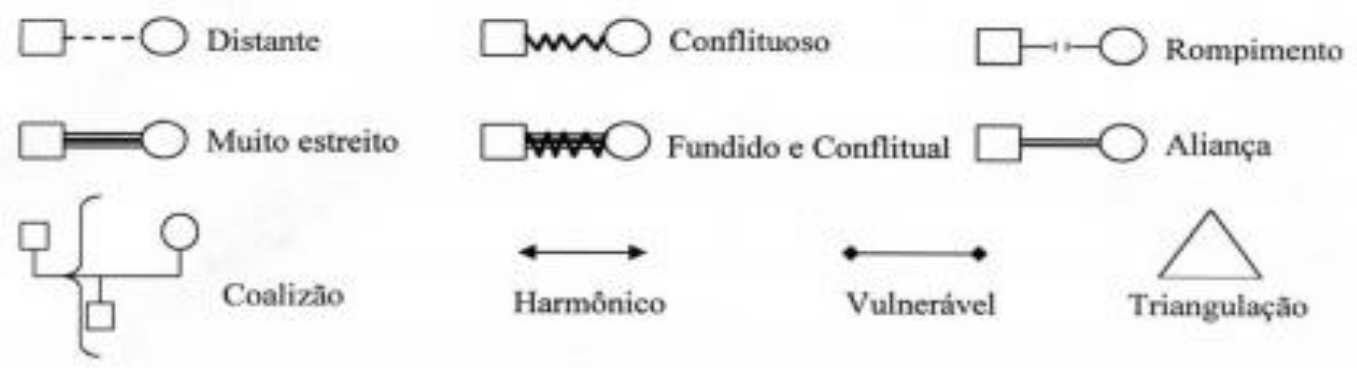


ANEXO 2 - Aprovação da Pesquisa junto ao Comitê de Ética

Universidade de Săo Paulo

Facuidade de Filosofia, Ciéncias e Letras de Ribeiráo Preto Comitê de Ética em Pesquisa

OECETPIFFCLRP-USPIOT0-dgfs

Compus de Riberato Preso

Rbeiras Preto, 31 de julho de 2015

Prezada Pesquisadora.

Comunicames a V. Sa. que o projeto de pesquisa intitulado - A experiência da paternidade na meia-idade na perspectiva de pais, māes e de seusisuas filhos(as) foi rearnalisado pelo Comite de Etica em Pesquisa da FFCLRP-USP, em sua $145^{\circ}$ Reuniao Ordinaria, realzada em 30.07.2015, e enquadrado na categoria: APROVADO /CNAE n. 43882215.4 .0000 .5407$)$

Solicitamos que eventuais modificapoes ou emendas ao projeto de pesquiss sejam apresentadas ao CEP. de sorma sucinta, idertificando a parte do projeto a sar modificada e suas justificativas, e que, ao término do estudo, um relatório final seja entregue, via Plataforma Brasil.

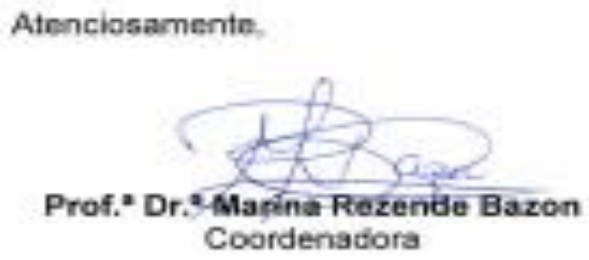

\section{A Senhora}

Mayara Colleti

Programa de Pbs - Graduaça em Psicologia da FFCLRPISP 


\section{APÊNDICE A- Formulário de Dados Sociodemográficos - uso exclusivo do LEPPS@}

Nome: Idade:

Sexo: ( ) Masculino ( ) Feminino Data de nascimento: I_-_-_

Endereço:

Bairro:

CEP:

Contato:

Telefone: Celular:

E-mail: Situação conju gal:

Tempo de namoro: anos Tempo de casamento/união estável: anos Escolaridade (cursou até que série completa):

Naturalidade: Procedência (cidade onde reside): Profissão/ocupa ção atual:

Ativa ( ) Afastada ( ) Aposentada ( )

Horas de trabalho por dia Tempo integral ( ) Tempo parcial ( )

Há quanto tempo trabalha neste emprego?

$2^{\mathrm{a}}$ a $6^{\mathrm{a}}$ feira ( ) $2^{\mathrm{a}}$ a sábado ( ) $2^{\mathrm{a}}$ a domingo ( ) trabalha por escala ( )

Renda mensal pessoal: $\mathrm{R} \$$

Renda familiar (soma dos rendimentos de todos os que contribuem no orçamento doméstico) $\mathrm{R} \$$ :

Outros que contribuem: Não ( ) Sim ( ) Quem?

Valor R\$: Número de pessoas que contribuem para o sustento da casa:

Religião: Praticante: ( ) sim ( ) não Frequência semanal:

Faz parte de algum grupo? De que tipo? Com que frequência?

\section{Composição familiar:}

Tipo de família: () nuclear ( ) extensiva ( ) extensiva recasada ( ) recasada

( ) monoparental

Filhos: () sim ( ) não Quantos:

Quem mora na casa? (sexo, idade, profissão de cada membro familiar, colocar os filhos de acordo com a ordem de nascimento).

\begin{tabular}{|l|l|l|l|l|l|}
\hline Nome & Parentesco & Sexo & Idade & Profissão & Rendimentos(R\$) \\
\hline & & & & & \\
\hline & & & & & \\
\hline
\end{tabular}

Tipo de moradia atual: casa () apartamento ( ) outra ( )

Situação da moradia: própria () alugada ( ) financiada ( ) cedida ( ) outra ( ) 
(Associação Brasileira de Empresas de Pesquisa - ABEP) - 2015

Agora vou fazer algumas perguntas sobre itens do domicilio para efeito de classificação econômica. Todos os itens de eletroeletrônicos que vou citar devem estar funcionando, incluindo os que estão guardados. Caso não estejam funcionando, considere apenas se tiver intenção de consertar ou repor nos próximos seis meses. INSTRUÇÃO: Todos os itens devem ser perguntados pelo entrevistador e respondidos pelo entrevistado. Vamos começar? No domicílio tem (LEIA CADA ITEM)

\begin{tabular}{|c|c|c|c|c|c|}
\hline ITENS DE CONFORTO & $\begin{array}{l}\text { NARO } \\
\text { POSSUI }\end{array}$ & 1 & 2 & 3 & $4+$ \\
\hline \multicolumn{6}{|l|}{$\begin{array}{l}\text { Quantidade de automóveis de passeio exclusivamente para } \\
\text { uso particular }\end{array}$} \\
\hline \multicolumn{6}{|l|}{$\begin{array}{l}\text { Quantidade de empregados mensalistas, considerando apenas } \\
\text { os que trabalham pelo menos cinco dias por semana }\end{array}$} \\
\hline \multicolumn{6}{|l|}{ Quantidade de máquinas de lavar roupa, excluindo tanquinho } \\
\hline \multicolumn{6}{|l|}{ Quantidade de banheiros } \\
\hline \multicolumn{6}{|l|}{$\begin{array}{l}\text { DVD, incluindo qualquer dispositivo que leia DVD e desconsiderando } \\
\text { DVD de automóvel }\end{array}$} \\
\hline \multicolumn{6}{|l|}{ Quantidade de geladeiras } \\
\hline \multicolumn{6}{|l|}{ Quantidade de freezers independentes ou parte da geladeira duplex } \\
\hline \multicolumn{6}{|l|}{$\begin{array}{l}\text { Quantidade de microcomputadores, considerando computadores } \\
\text { de mesa, laptops, notebooks e netbooks e desconsiderando tablets, } \\
\text { palms ou smartphones }\end{array}$} \\
\hline \multicolumn{6}{|l|}{ Quantidade de lavadora de louças } \\
\hline \multicolumn{6}{|l|}{ Quantidade de fornos de micro-ondas } \\
\hline \multicolumn{6}{|l|}{$\begin{array}{l}\text { Quantidade de motocicletas, desconsiderando as } \\
\text { usadas exclusivamente para uso profissional }\end{array}$} \\
\hline $\begin{array}{l}\text { Quantidade de máquinas secadoras de roupas, considerando lava } \\
\text { e seca }\end{array}$ & & & & & \\
\hline
\end{tabular}

A água utilizada neste domicilio é proveniente de?

\begin{tabular}{|c|l|}
\hline A água utillizada neste domicilio é proveniente de? \\
\hline 1 & Rede geral de distribuiçăo \\
\hline 2 & Poço ou nascente \\
\hline 3 & Outro meio \\
\hline
\end{tabular}

Considerando o trecho da rua do seu domicilio, você díria que a rua é:

\begin{tabular}{|l|l|}
\hline Considerando o trecho da rua do seu domicilio, voce diria que a rua é: \\
\hline 1 & Asfaltada/Pavimentada \\
\hline 2 & Terra/Cascalho \\
\hline
\end{tabular}


Qual é o grau de instrução do chefe da família? Considere como chefe da família a pessoa que contribui com a maior parte da renda do domicílio.

\begin{tabular}{|l|l|}
\hline \multicolumn{1}{|c|}{ Nomenclatura atual } & \multicolumn{1}{c|}{ Nomenclatura anterior } \\
\hline Analfabeto / Fundamental I incompleto & Analfabeto/Primário Incompleto \\
\hline $\begin{array}{l}\text { Fundamental I completo / Fundamental II } \\
\text { incompleto }\end{array}$ & $\begin{array}{l}\text { Primário Completo/Ginásio } \\
\text { Incompleto }\end{array}$ \\
\hline $\begin{array}{l}\text { Fundamental completo/Médio } \\
\text { incompleto }\end{array}$ & $\begin{array}{l}\text { Ginásio Completo/Colegial } \\
\text { Incompleto }\end{array}$ \\
\hline Médio completo/Superior incompleto & $\begin{array}{l}\text { Colegial Completo/Superior } \\
\text { Incompleto }\end{array}$ \\
\hline Superior completo & Superior Completo \\
\hline
\end{tabular}




\section{APÊNDICE B - Roteiro de Entrevista Semiestruturada (Pai)}

\section{Dados do participante}

Nome:

Idade:

Profissão:

Escolaridade:

Religião:

\section{História de vida}

- Me conte, com suas palavras, a sua história de vida até este momento

- Me conte um pouco sobre a sua infância

○ Como era a sua relação com os seus pais?

- Conte-me alguma ocasião que o marcou na relação com os seus pais [pode ser um dia marcante, uma situação especial, alguma recordação importante]

- Me conte um pouco sobre a sua adolescência [se ele tiver dificuldades, pode contar sobre um dia marcante de sua adolescência]

- Me conte um pouco sobre a sua vida atual [o que faz, no que trabalha, o que gosta de fazer em seu tempo livre, sua formação es colar e profissional]

\section{Conjugalidade}

- Me fale sobre o seu casamento [ou união consensual].

○ Como conheceu sua esposa?

○ Há quantos anos estão juntos?

- Como é o seu cotidiano com a sua esposa?

- O que considera mais importante no seu casamento?

\section{Transição para a parentalidade}

- Conte-me como foi o processo de se tornar pai.

○ Você sempre desejou ter filho(s)? Quais eram as expectativas?

○ Qual foi a reação diante da notícia de concepção?

○ Como foi a preparação para a chegada do filho?

- Conte-me sobre seu relacionamento com sua esposa durante a gestação?

\section{Paternidade}

- Houve alguma mudança na relação sua com sua esposa após a sua experiência como pai?

- Houve alguma mudança na relação seus familiares após a paternidade?

- E com os seus amigos e pessoas mais próximas?

- Como você define a sua relação com seu filho?

- Relate um momento difícil que você passou com seu filho. 
- $\quad$ Relate um momento alegre que você vivenciou com seu filho.

- Quais atividades vocês realizam juntos?

- Há alguma(s) atividade(s) que você não realiza com seu filho e que desejaria realizar (ou realizar mais frequentemente)?

- Você tem ou teve alguma dificuldade no exercício da paternidade?

- Você considera que ter se tornado pai após os 40 anos the trouxe alguma dificuldade? E facilidades?

- Agora gostaria que você deixasse a imaginação livre e pensasse: Como você acredita que seria se você tivesse se tornado pai quando jovem? Como seria a relação com seu filho? Em que seria semelhante ou diferente da de hoje?

- Há atividades que seu filho realiza apenas com sua esposa?

- O que é ser pai para você?

- O que é ser pai depois dos 40 anos?

- Para você, o que é família?

- O que você considera mais importante em uma família? O que não pode faltar em uma família?

- Você gostaria que mudasse alguma coisa em sua vida familiar?

\section{Planos para o futuro}

- Quais são seus planos de vida para o futuro?

- O que você deseja realizar com seu filho daqui a alguns anos?

- Você deseja ter mais filhos?

- Se você pudesse imaginar sua vida daqui a10 anos, como você se imagina? Onde e com quem estaria? Como gostaria que seu filho estivesse?

\section{Considerações finais}

- Gostaria de dizer mais alguma coisa que não tenha sido abordada durante a entrevista? 


\section{APÊNDICE C - Roteiro de Entrevista Semiestruturada (Mãe)}

\section{Dados do participante}

Nome:

Idade:

Profissão:

Escolaridade:

Religião:

\section{Conjugalidade}

- Me fale sobre o seu casamento [ou união consensual].

○ Como conheceu seu esposo?

○ Há quantos anos estão juntos?

- Como é o seu cotidiano com seu esposo?

- O que considera mais importante no seu casamento?

\section{Transição para a parentalidade}

- Você sempre desejou ter filho(s)? Quais eram suas expectativas?

○ Qual foi a reação de seu esposo diante da notícia de concepção?

- Como foi a preparação para a chegada do(a) filho(a)?

- Conte-me sobre seu relacionamento com seu esposo durante a gestação? Houve alguma mudança na relação sua com seu esposo após o nascimento do bebê?

\section{Percepção acerca da paternidade}

- Para você o que é ser um bom pai?

- Como você define seu esposo como pai?

- Como você define a relação do seu esposo com seu filho?

- Há alguma atividade que apenas você realiza com seu filho?

- Há alguma atividade que apenas seu esposo realiza com seu filho?

- Você acredita que ter se tornado pai após os 40 anos trouxe alguma dificuldade para seu esposo? E facilidades?

- Você acredita que há alguma diferença no exercício da paternidade de pais mais jovens e de pais com a idade de seu esposo?

- Agora gostaria que você deixasse a imaginação livre e pensasse: Como você acredita que seu esposo seria se ele tivesse se tornado pai quando jovem? Como seria a relação com seu filho? Em que seria semelhante ou diferente do que é?

- Para você, o que é família?

- O que você considera mais importante em uma família? O que não pode faltar em uma família?

- Você gostaria que mudasse alguma cois a em sua vida familiar? 


\section{Planos para o futuro}

- Quais são seus planos de vida para o futuro?

- Você deseja ter mais filhos?

- Se você pudesse imaginar sua vida daqui a10 anos, como você se imagina? Onde e com quem seu esposo estaria? Como gostaria que seu filho estivesse? Como imagina a relação do seu filho com seu esposo?

\section{Considerações finais}

- Gostaria de dizer mais alguma coisa que não tenha sido abordada durante a entrevista? 


\section{APÊNDICE D - ROTEIRO DE ENTREVISTA SEMIES TRUTURADA (FILHOS/AS)}

\section{Dados do participante}

Nome:

Idade:

Escolaridade:

- Me conte um pouco de como é um dia normal de sua vida, desde a hora que você acorda até a hora em que vai dormir (dia de semana).

- Agora me conte como é um final de semana.

- Quais atividades você realiza com seus pais?

- Me conte sobre atividades que você realiza apenas com seu pai. Agora me conte de atividades que você realiza apenas com sua mãe.

- Tem alguma atividade que você não realiza com seu pai e que gostaria de realizar?

- Você consegue me dizer o que você acha que seu pai mais gosta de fazer?

- Você pode me contar alguma situação engraçada que tenha acontecido com você e com seu pai? Você pode me contar alguma situação desagradávelque tenha acontecido com você e com seu pai?

- Você tem algum amigo que tem um pai mais jovem (novo) que o seu? Se sim: Ele faz alguma coisa com o pai dele que você não faz com o seu?

- Como você acha que é ter um pai mais jovem?

- Você gostaria de mudar alguma coisa na sua família?

- Do que você tem medo? O que deixa você alegre? O que faz você ficar triste?

- $\quad$ O que faz o seu pai ficar feliz? O que faz o seu pai ficar triste?

- Como você imagina sua família no futuro? Quais são seus planos?

- Como você imagina seu pai daqui a 10 anos? Como você acha que ele vai estar? O que vocês estarão fazendo juntos? O que gostaria de fazer com ele?

- Gostaria de me dizer mais alguma coisa que ainda não falamos em nossa conversa? 


\section{Apêndice E - Termo de Consentimento Livre e Esclarecido}

(Membros do Casal)

\section{Termo de Esclarecimento}

Meu nome é Mayara Colleti, sou mestranda do Programa de Pós-graduação em Psicologia da Faculdade de Filosofia, Ciências e Letras de Ribeirão Preto da Universidade de São Paulo (FFCLRP-USP) e, sob orientação do Prof. Dr. Manoel Antônio dos Santos, que é psicólogo e professor da FFCLRP-USP, estou realizando uma pesquisa na modalidade de mestrado intitulada "A experiência da paternidade na meia-idade na perspectiva de pais, mães e de seus/suas filhos(as)".

O objetivo deste projeto é compreender a experiência da paternidade na meia-idade a partir da percepção de pais, mães e filhos envolvidos. Ao aceitar participar desse estudo você estará contribuindo para que saibamos mais sobre a temática, possibilitando novas discussões sobre as vivências da paternidade na meia-idade.

Caso esteja de acordo, você participará de alguns encontros comigo. Nestes encontros, inicialmente você irá participar de uma entrevista, a sós comigo, em que iremos conversar sobre sua experiência e percepção da paternidade na meia-idade. Esta entrevista permitirá que você fale de sua experiência e também que eu lhe faça algumas perguntas de aprofundamento e esclarecimento, a fim de alcançar o objetivo do meu estudo. Desta forma, é possível que seja necessário mais de um encontro para a realização desta conversa.

Em seguida, em outro encontro, eu irei propor que você desenhe para mim uma família e me conte uma estória sobre ela. Posteriormente, em outro encontro, nós desenharemos, juntamente com seu cônjuge e seu/sua filho(a), uma mapa de sua família. Esta atividade contribuirá para que eu possa a compreender a composição familiar de vocês e o modo com que vocês se relacionam com os demais membros da família.

Durante esses encontros pretendo realizar a gravação de nossa conversa emáudio, com a finalidade de garantir que nada do que você me disser pas sará despercebido ou será esquecido. Para tanto, também preciso de sua autorização por escrito, mostrando que está de acordo que nossa conversa seja gravada. Ao dar seu consentimento, você também estará concordando com o fato de que a gravação realizada em áudio seja transcrita e que o material produzido possa ser utilizado por mim, exclusivamente para fins de pesquisa, preservando os valores éticos quanto aos dados fornecidos, de acordo com as diretrizes que regem a realização de pesquis as com seres humanos. Manterei guardada essa gravação por um período de até cinco anos na sala do Laboratório de Ensino e Pesquisa em Psicologia da Saúde - LEPPS, situado no Departamento de Psicologia, Avenida Bandeirantes, 3900, Bloco 5, sala 34 da Faculdade de Filosofia, Ciências e Letras de Ribeirão Preto, Universidade de São Paulo, Monte Alegre, 14.040-901 - Ribeirão Preto-SP. Depois desse prazo o áudio será descartado.

Necessito de sua colaboração, mas você precisa estar ciente de que sua participação é inteiramente voluntária e não lhe trará nenhum tipo de beneficio direto, como remuneração ou outra vantagem es pecial. Não haverá nenhuma forma de reembolso ou ressarcimento, já que você não terá nenhum gasto com a participação na pesquisa. Além disso, fica-lhe assegurada total liberdade de desistir de participar do estudo e se retirar da pesquisa a qualquer momento em que desejar fazê-lo, quando não mais interessado ou disposto a prosseguir 
colaborando, sem que isso implique qualquer prejuízo ou acarrete alguma penalidade, represália ou constrangimento à sua pessoa.

Mesmo não correndo nenhum risco em participar desta pesquisa, alguns conteúdos abordados podem trazer algum tipo de desconforto psicológico. Caso isso aconteça, você poderá conversar comigo, que sou psicóloga, ou poderá ser encaminhada para acompanhamento especializado. Conforme as leis vigentes no país, como participante da pesquisa você tem direito à indenização, caso ocorra dano decorrente de sua participação neste estudo, por parte do pesquis ador, do patrocinador e das instituições envolvidas nas diferentes fases desta pesquisa.

As informações que você me fornecer poderão ser apresentadas em eventos científicos e publicadas em periódicos científicos, porém sempre mantendo seu anonimato, de modo que sua identidade será preservada.

Caso você tenha eventuais dúvidas em relação a questões éticas do meu projeto, você poderá entrar contato com o Comitê de Ética em Pesquisa da Faculdade de Filosofia, Ciências e Letras de Ribeirão Preto - USP, localizado na Avenida Bandeirantes, 3900 - Bloco 23 - Casa 37, pelo telefone (16) 3315-4811 / Fax: (16) 3633-2660 e/ou pelo e-mail: coetp@ffclrp.usp.br

Considerando o que foi explicado acima, declaro que:

Fui informado(a) de que a minha participação nesta pesquisa é inteiramente voluntária, podendo ser interrompida a qualquer momento, sem que is so possa acarretar qualquer tipo de consequência para mim. Estou ciente de que minha participação será registrada por meio de gravações de áudio, com o que consinto voluntariamente, desde que as mesmas sejam utilizadas com objetivos de pesquisa. Estou ciente de que a divulgação do material produzido irá resguardar meu anonimato. Estou ciente também de que todo material derivado de minha colaboração será utilizado com objetivo exclusivo de pesquisa e que serão tomados os demais cuidados éticos necessários para preservar meus direitos à intimidade e dignidade pessoal. Fui informado(a) ainda que a pesquisadora responsável por esse projeto poderá realizar apresentações em eventos científicos, bem como publicar os resultados deste estudo em periódicos científicos, respeitando-se os limites éticos aqui afirmados.

Considero que fui esclarecido(a) em minhas dúvidas a respeito deste estudo e estou informado(a) de que tenho a disponibilidade da pesquisadora para prestar esclarecimentos em relação a eventuais dúvidas que possam surgir no decorrer da pesquisa. Também estou ciente de que terei acesso aos resultados deste estudo após sua conclusão, caso eu tenha interesse, e que posso retirar a minha concordância em qualquer etapa da pesquisa.

Considerando o exposto, aceito participar voluntariamente deste estudo.

Diante do exposto, eu,

declaro que estou ciente das informações recebidas e que concordo voluntariamente em participar des ta pesquisa. Atesto que recebi uma via deste Termo e a possibilidade de lê-lo, o que me permitirá entrar em contato com os pesquisadores em outro momento, caso eu deseje ou sinta necessidade de obter novos esclarecimentos a respeito desta pesquisa. Também autorizo a minha participação no projeto, permitindo a gravação da entrevista e a utilização dos dados aqui coletados, desde que respeitado o sigilo e o anonimato.

de de 2015. 
Assinatura do(a) Participante:

\section{Mayara Colleti}

Mestranda do Programa de Pós-graduação em Psicologia da FFCLRP-USP

Telefone: (16) 98196-1733. E-mail: mayara_colleti@hotmail.com

Prof. Dr. Manoel Antônio dos Santos

Professor Associado 3 do Programa de Pós-graduação em Psicologia da FFCLRP-USP

Orientador da pesquisa

\section{Contato:}

Pesquisadores-responsáveis: (16) 98196-1733 (Mayara Colleti), de $2^{\mathrm{a}}$ a $6^{\mathrm{a}}$ feira, das 8 às 17 horas. E-mail: mayara_colleti@hotmail.com

Ou (16) 98132-9896 (Manoel Antônio dos Santos), de $2^{\mathrm{a}}$ a $6^{\mathrm{a}}$ feira, das 8 às 17 horas. E-mail: masantos@ffclrp.usp.br 


\section{APÊNDICE F -Termo de Consentimento Livre e Esclarecido}

(Autorização dos Pais - filhos com idade igual ou superior a 12 anos)

Meu nome é Mayara Colleti, sou mestranda do Programa de Pós-graduação em Psicologia da Faculdade de Filosofia, Ciências e Letras de Ribeirão Preto da Universidade de São Paulo (FFCLRP-USP) e, sob orientação do Prof. Dr. Manoel Antônio dos Santos, que é psicólogo e professor da FFCLRP-USP, estou realizando uma pesquisa na modalidade de mestrado, intitulada: A Experiência da paternidade na meia-idade na perspectiva de pais, mães e de seus/suas filhos(as).

O objetivo deste projeto de pesquisa é compreender a experiência da paternidade na meia-idade a partir da percepção de pais, mães e filhos envolvidos. Para tanto, preciso da colaboração dos pais, mães e de seus/suas filhos(as), e gostaria que você consentisse com a participação de sua/sua filho(a). Caso esteja de acordo que ele(a) colabore com este estudo, ele(a) irá participar de um encontro a sós comigo, em que eu irei propor que seu/sua filho(a) desenhe para mim uma família e participe de uma entrevista, a sós comigo, em que iremos conversar sobre seu dia a dia, rotina familiar e percepções e singularidades acerca de sua relação com seu pai. Esta entrevista permitirá que ele(a) fale sobre diversos aspectos de sua rotina com cada um de vocês e também que eu lhe faça algumas perguntas de aprofundamento e esclarecimento, a fim de alcançar o objetivo do meu estudo. Desta forma, é possível que seja necessário mais de umencontro para a realização desta conversa.

Em seguida, durante outro encontro, eu irei propor que seu/sua filho(a) desenhe para mim uma família e me conte uma estória sobre ela. Posteriormente, em outro encontro, eu irei propor que vocês e seu/sua filho(a) desenhe, com meu auxílio, uma mapa da família. Esta atividade contribuirá para que eu possa a compreender a composição familiar de vocês e o modo com que vocês se relacionam com os demais membros da família.

Durante esses encontros pretendo realizar a gravação de nossa conversa emáudio, com a finalidade de garantir que nada do que você me dis ser passará despercebido ou será esquecido. Para tanto, também preciso de sua autorização por escrito, mostrando que está de acordo que nossa conversa seja gravada. Ao dar seu consentimento, você também estará concordando com o fato de que a gravação realizada em áudio seja transcrita e que o material produzido possa ser utilizado por mim, exclusivamente para fins de pesquisa, preservando os valores éticos quanto aos dados fornecidos, de acordo com as diretrizes que regem a realização de pesquisas com seres humanos. Manterei guardada essa gravação por um período de até cinco anos na sala do Laboratório de Ensino e Pesquisa em Psicologia da Saúde - LEPPS, situado no Departamento de Psicologia, Avenida Bandeirantes, 3900, Bloco 5, sala 34 da Faculdade de Filosofia, Ciências e Letras de Ribeirão Preto, Universidade de São Paulo, Monte Alegre, 14.040-901 - Ribeirão Preto-SP. Depois desse prazo o áudio será descartado.

Necessito de sua colaboração, mas você precisa estar ciente que a participação de seu/sua filho(a) é inteiramente voluntária e não lhe trará nenhum tipo de beneficio direto, como remuneração ou outra vantagem especial. Não haverá nenhuma forma de reembolso ou ressarcimento, já que você não terá nenhum gas to com a participação na pesquisa. Além disso, fica-lhe assegurada total liberdade de desistir de participar do estudo e se retirar da pesquisa a qualquer momento em que desejar fazê-lo, quando não mais interessado(a) ou disposto(a) a prosseguir colaborando, sem que is so implique qualquer prejuízo ou acarrete alguma penalidade, represália ou constrangimento à sua pessoa. 
O fato de seu/sua filho(a) participar deste estudo não envolve riscos previsíveis à participante. Contudo, algumas questões abordadas podem gerar algum tipo de desconforto psicológico. Caso isso aconteça, ele/ela poderá conversar comigo, que sou psicóloga, ou poderá ser encaminhada para acompanhamento especializado. Conforme as leis vigentes no país, como participante da pesquisa ela tem direito à indenização, caso ocorra dano decorrente de sua participação neste estudo, por parte do pesquisador, do patrocinador e das instituições envolvidas nas diferentes fases desta.

As informações que seu/sua filho(a) me fornecer poderão ser apresentadas em eventos científicos e publicadas em periódicos científicos, porém sempre mantendo seu anonimato, de modo que sua identidade será preservada.

Caso você tenha eventuais dúvidas em relação a questões éticas do meu projeto, você poderá entrar contato com o Comitê de Ética em Pesquisa da Faculdade de Filosofia, Ciências e Letras de Ribeirão Preto - USP, localizado na Avenida Bandeirantes, 3900 - Bloco 23 - Casa 37, pelo telefone (16) 3315-4811 / Fax: (16) 3633-2660 e/ou pelo e-mail: coetp@ ffclrp.usp.br

Considerando o que foi explicado acima, declaro que:

Fui informado(a) de que participação do meu/minha filho(a) nesta pesquisa é inteiramente voluntária, podendo ser interrompida a qualquer momento, sem que is so possa acarretar qualquer tipo de consequência para mim. Estou ciente de que sua participação será registrada por meio de gravações de áudio, com o que consinto voluntariamente, desde que as mesmas sejam utilizadas com objetivos de pesquisa. Estou ciente de que a divulgação do material produzido irá resguardar seu anonimato. Estou ciente também de que todo material derivado da colaboração dele(a) será utilizado com objetivo exclusivo de pesquisa e que serão tomados os demais cuidados éticos necessários para preservar meus direitos à intimidade e dignidade pessoal. Fui informado(a) ainda que a pesquisadora responsável por esse projeto poderá realizar apresentações em eventos científicos, bem como publicar os resultados deste estudo em periódicos científicos, respeitando-se os limites éticos aqui afirmados.

Considero que fui esclarecido(a) em minhas dúvidas a respeito deste estudo e estou informado(a) de que tenho a disponibilidade da pesquisadora para prestar esclarecimentos em relação a eventuais dúvidas que possam surgir no decorrer da pesquisa. Também estou ciente de que terei acesso aos resultados deste estudo após sua conclusão, caso eu tenha interesse, e que posso retirar a minha concordância em qualquer etapa da pesquisa.

Considerando o exposto, aceito participar voluntariamente deste estudo.

Diante do exposto, eu,

declaro que estou ciente das informações recebidas e que concordo que meu/minha filho(a) participe voluntariamente desta pesquisa. Atesto que recebi uma via deste Termo e a possibilidade de lê-lo, o que me permitirá entrar em contato com os pesquisadores em outro momento, caso eu deseje ou sinta necessidade de obter novos esclarecimentos a respeito desta pesquisa.

de de 2015 .

Assinatura do(a) participante: 
Mayara Colleti

Mestranda do Programa de Pós-graduação em Psicologia da FFCLRP-USP

Prof. Dr. Manoel Antônio dos Santos

Professor Associado 3 do Programa de Pós-graduação em Psicologia da FFCLRP-USP

Orientador da pesquisa

\section{Contato:}

Pesquisadores-responsáveis: (16) 98196-1733 (Mayara Colleti), de $2^{\mathrm{a}}$ a $6^{\mathrm{a}}$ feira, das 8 às 17 horas. E-mail: mayara_colleti@hotmail.com

Ou (16) 98132-9896 (Manoel Antônio dos Santos), de $2^{\mathrm{a}}$ a $6^{\mathrm{a}}$ feira, das 8 às 17 horas. E-mail: masantos@ffclrp.usp.br 


\section{APÊNDICE G - Termo de Assentimento}

(participantes de 12 a 17 anos)

Meu nome é Mayara Colleti, sou aluna do Programa de Pós-graduação em Psicologia da Faculdade de Filosofia, Ciências e Letras de Ribeirão Preto da Universidade de São Paulo (FFCLRP-USP) e, sob orientação do Prof. Dr. Manoel Antônio dos Santos, que é psicólogo e Professor Associado da FFCLRPUSP, estou realizando uma pesquisa na modalidade de mestrado, intitulada: A Experiência da paternidade na meia-idade na perspectiva de pais, mães e de seus/suas filhos(as).

O objetivo deste projeto de pesquisa é compreender a experiência da paternidade na meia-idade a partir da percepção de pais, mães e filhos envolvidos. Para tanto, preciso da colaboração dos pais, mães e de seus/suas filhos(as) e gostaria que você fosse uma das pessoas a participar deste estudo. Eu já obtive o consentimento de seu pai/sua mãe para que você possa participar, caso queira. Assim, caso aceite, você irá participar de alguns encontros comigo. Nestes encontros, inicialmente você irá participar de uma entrevista, a sós comigo, em que iremos conversar sobre seu dia a dia, rotina familiar e percepções e singularidades acerca de sua relação com seu pai. Esta entrevis ta permitirá que você fale sobre aquilo que achar importante de sua rotina e atividades que realiza com seus pais e também que eu lhe faça algumas perg untas de aprofundamento e esclarecimento, a fim de alcançar o objetivo do meu estudo. Desta forma, é possível que seja necessário mais de um encontro para a realização desta conversa.

Em seguida, durante outro encontro, eu irei propor que você desenhe para mim uma família e me conte uma estória sobre ela. Posteriormente, em outro encontro, eu irei propor que nós desenhamos, juntamente com seus pais, um mapa de sua família. Esta atividade contribuirá para que eu possa a compreender a composição familiar de vocês e o modo com que vocês se relacionam com os demais membros da família.

Durante nossos encontros eu pretendo realizar a gravação de nossas conversas e para is so preciso que você aceite e me de sua autorização por escrito. Todas as atividades serão feitas respeitando suas características e limites, procurando deixar você à vontade com a situação. Se em algum momento você se sentir desconfortável ou perder o interesse pela atividade, ela será interrompida.

Esse material será utilizado somente para o meu estudo e será guardado e mantido em sigilo. Ou seja, as informações que você me fornecer serão utilizadas exclusivamente para a finalidade da pesquisa e nos trabalhos científicos que vou produzir. Você não será identificado, garantindo assim o seu anon imato. Não há nenhum risco significativo para você participar desta pesquisa e qualquer dúvida que tenha a respeito deste termo ou sobre a atividade proposta poderá ser esclarecida a qualquer momento. Mes mo não correndo risco previsível em participar desta pesquisa, alguns conteúdos abordados podem trazer algum tipo de desconforto psicológico. Caso aconteça de você experimentar algum tipo de desconforto, poderá conversar comigo, que sou psicóloga ou, ser encaminhado(a) para atendimento psicológico na Clínica Psicológica do Centro de Psicologia Aplicada da FFCLRP-USP.

Necessito de sua colaboração, mas você precisa saber que sua participação é inteiramente voluntária e não lhe trará nenhum tipo de beneficio direto, como remuneração ou outra vantagem especial. Além disso, você poderá a qualquer momento desistir de participar do estudo e se retirar da pesquisa a qualquer momento, sem que is so lhe traga qualquer prejuízo ou constrangimento. 
Caso você tenha eventuais dúvidas em relação a questões éticas do meu projeto, você poderá entrar contato com o Comitê de Ética em Pesquisa da Faculdade de Filosofia, Ciências e Letras de Ribeirão Preto - USP, localizado na Avenida Bandeirantes, 3900 - Bloco 23 - Casa 37, pelo telefone (16) 3315-4811 / Fax: (16) 3633-2660 e/ou pelo e-mail: coetp@ffclrp.usp.br.

Este termo encontra-se impresso em duas vias, sendo que uma via será arquivada pela pesquisadora-responsável, e a outra será entregue a você.

Considerando o que foi explicado acima, declaro que:

Fui informado(a) sobre os objetivos da pesquisa de maneira clara e detalhada e que pude esclarecer minhas dúvidas em relação a este estudo. Sei que poderei desistir da participação na pesquisa a qualquer momento e que meus responsáveis legais também poderão mudar a decisão que autoriza que eu participe. Tendo o consentimento dos meus responsáveis já assinado, declaro que concordo em participar desta pesquisa e que estou ciente de que minha participação será registrada por meio de gravações de áudio. Estou ciente também de que todo material derivado de minha colaboração será utilizado com objetivo exclusivo de pesquisa e que serão tomados os demais cuidados éticos necessários para preservar meus direitos à intimidade e dignidade pessoal.

Considerando o exposto, aceito participar voluntariamente deste estudo.

$\mathrm{Eu}$, (nome da participante), recebi uma via deste Termo e tive a possibilidade de lê-lo com atenção antes de firmá-lo, após o que aceitei participar deste estudo, sabendo que tal participação é livre e inteiramente voluntária.

de de 2015 .

Assinatura do(a) participante:

Mayara Colleti

Mestranda do Programa de Pós-graduação em Psicologia da FFCLRP-USP

Prof. Dr. Manoel Antônio dos Santos

Professor Associado 3 do Programa de Pós-graduação em Psicologia da FFCLRP-USP

Orientador da pesquisa

\section{Contato:}

Pesquisadores-responsáveis: (16) 98196-1733 (Mayara Colleti), de $2^{\mathrm{a}}$ a $6^{\mathrm{a}}$ feira, das 8 às 17 horas. E-mail: mayara_colleti@hotmail.com

Ou (16) 98132-9896 (Manoel Antônio dos Santos), de $2^{\mathrm{a}}$ a $6^{\mathrm{a}}$ feira, das 8 às 17 horas. E-mail: masantos@ffclrp.usp.br 